NBER WORKING PAPER SERIES

\title{
CHILDHOOD CIRCUMSTANCES AND ADULT OUTCOMES:
} ACT II

\author{
Douglas Almond \\ Janet Currie \\ Valentina Duque \\ Working Paper 23017 \\ http://www.nber.org/papers/w23017 \\ NATIONAL BUREAU OF ECONOMIC RESEARCH \\ 1050 Massachusetts Avenue \\ Cambridge, MA 02138 \\ January 2017
}

We thank Steven Durlauf and five anonymous referees for very helpful comments. The views expressed herein are those of the authors and do not necessarily reflect the views of the National Bureau of Economic Research. Almond thanks NSF award SES-1357608.

At least one co-author has disclosed a financial relationship of potential relevance for this research. Further information is available online at http://www.nber.org/papers/w23017.ack

NBER working papers are circulated for discussion and comment purposes. They have not been peer-reviewed or been subject to the review by the NBER Board of Directors that accompanies official NBER publications.

(C) 2017 by Douglas Almond, Janet Currie, and Valentina Duque. All rights reserved. Short sections of text, not to exceed two paragraphs, may be quoted without explicit permission provided that full credit, including (C) notice, is given to the source. 
Childhood Circumstances and Adult Outcomes: Act II

Douglas Almond, Janet Currie, and Valentina Duque

NBER Working Paper No. 23017

January 2017

JEL No. H4,I14

\begin{abstract}
$\underline{\text { ABSTRACT }}$
That prenatal events can have life-long consequences is now well established. Nevertheless, research on the Fetal Origins Hypothesis is flourishing and has expanded to include the early childhood (postnatal) environment. Why does this literature have a "second act?" We summarize the major themes and contributions driving the empirical literature since our 2011 reviews, and try to interpret the literature in light of an overarching conceptual framework about how human capital is produced early in life. One major finding is that relatively mild shocks in early life can have substantial negative impacts, but that the effects are often heterogeneous reflecting differences in child endowments, budget constraints, and production technologies. Moreover, shocks, investments, and interventions can interact in complex ways that are only beginning to be understood. Many advances in our knowledge are due to increasing accessibility of comprehensive administrative data that allow events in early life to be linked to long-term outcomes. Yet, we still know relatively little about the interval between, and thus about whether it would be feasible to identify and intervene with affected individuals at some point between early life and adulthood. We do know enough, however, to be able to identify some interventions that hold promise for improving child outcomes in early life and throughout the life course.

Douglas Almond

Department of Economics

Columbia University

International Affairs Building, MC 3308

420 West 118th Street

New York, NY 10027

and NBER

da2152@columbia.edu

Janet Currie

Department of Economics

Center for Health and Wellbeing

185A Julis Romo Rabinowitz Building

Princeton University

Princeton, NJ 08544

and NBER

jcurrie@princeton.edu

\author{
Valentina Duque \\ University of Michigan \\ Postdoctoral Fellow in the \\ Department of Economics \\ 426 Thompson Street \\ Room 2034 \\ Ann Arbor, MI 48104 \\ vduque@umich.edu
}

Population Studies Center and
\end{abstract}


The fetal origins literature has been particularly active over the last several years rendering reviews by Currie (2009) and Almond and Currie (2011a, b) somewhat dated. Figure 1 shows the number of papers about "fetal origins" in several leading journals by year. ${ }^{1}$

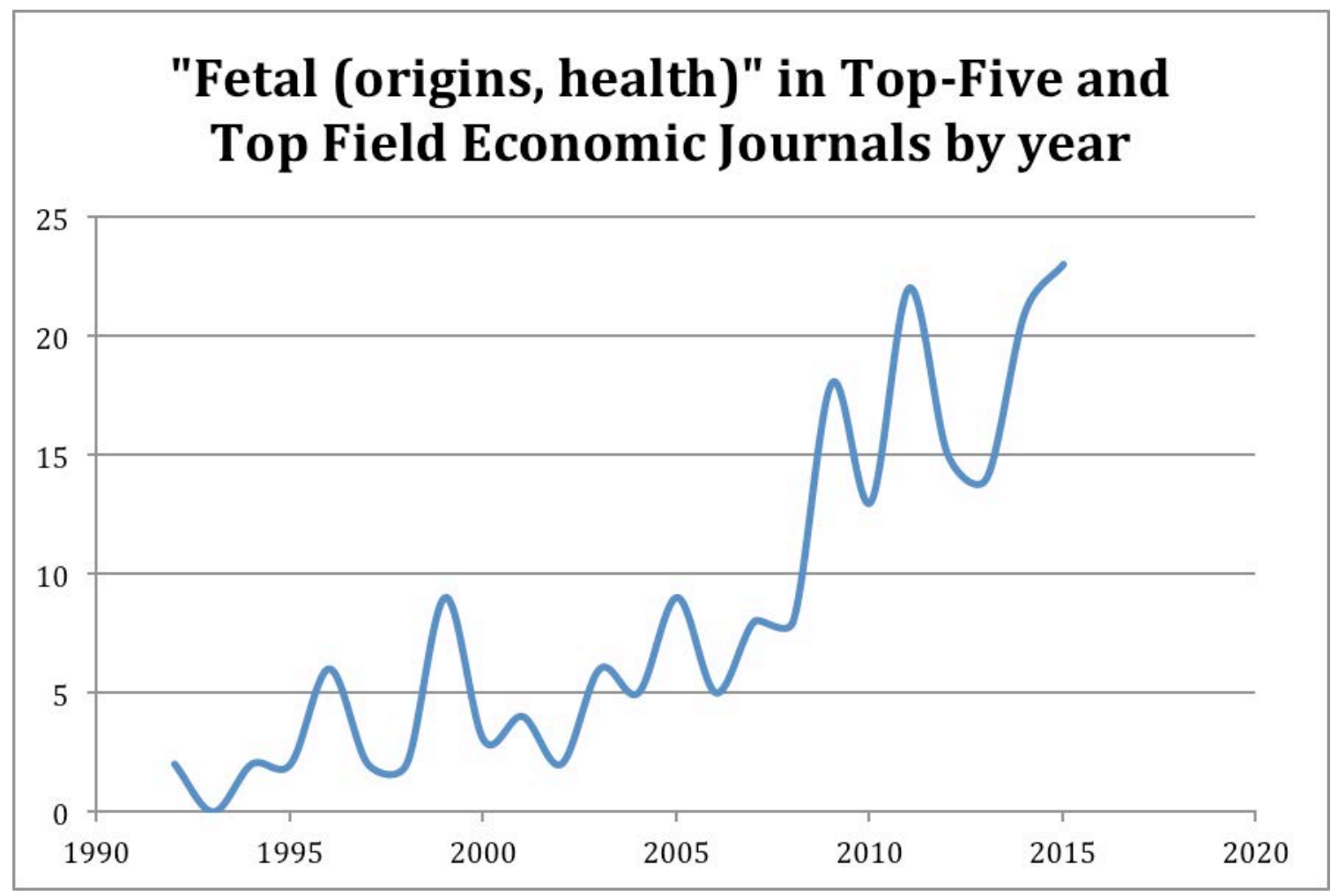

Why does this literature "have legs"? By now, the rudimentary point is familiar. Currie and Hyson (1999) using longitudinal data showed that long-term outcomes seemed to respond to circumstances in utero; Costa (2000) found that chronic health conditions among older men were predicted by early-life infant mortality rates in their natal areas, which can proxy for the disease environment. Papers exploiting natural experiments to show the long-term impact of fetal and

\footnotetext{
${ }^{1}$ Figure 1 shows the number of annual publications from January 1993 to October 2015 in the Quarterly Journal of Economics, American Economic Review, Journal of Political Economy, Econometrica, Review of Economic Studies, Journal of Labor Economics, Journal of Econometrics, Journal of the European Economic Association, Review of Economics and Statistics, Journal of Human Resources, Journal of Public Economics, American Economic Journal: Applied Economics, Journal of Development Economics, American Economic Journal: Economic Policy, and Journal of Health Economics.
} 
early life shocks such as Almond (2006), Van Den Berg et al. (2006), and Bleakley (2007), are a decade old.

One reason for continued interest is that the large magnitude of the fetal origins effects that have been found, and the short time interval in utero suggest that in principle, Pareto improvements can be made by re-allocating resources from later to earlier in the life cycle. Given the common definition of economics as the study of the allocation of scarce resources (e.g., Blackhouse and Medema, 2009), this literature resonates with a core interest of economists: efficiency. Of course, the separation in time and across people (first the mother then the child) makes it far from obvious how this potentially high-return reallocation of resources can best be achieved.

A second reason for enduring interest in the Fetal Origins Hypothesis $(\mathrm{FOH})$ is that it has proven to describe a surprisingly general phenomenon. Although FOH was first formulated as a specific theory about the effects of prenatal nutritional deprivation on chronic health conditions in adulthood (Barker, 1998), economists have found that a wide range of early life experiences matter and that many other (non-health) outcomes are affected. Outcomes of surpassing interest to economists, including IQ and wages, have been linked to early life influences, as have some newer areas of focus such as personality traits.

This evolving discovery speaks to another area of abiding interest for economics: the debate about nature versus nurture. It has become increasingly clear that we are shaped by many occurrences in early life which interact with our genetic endowments to either help or hinder us in reaching our potential and/or adapting to our environment (Manski, 2011). The FOH literature suggests that it may be possible to respond to entrenched disadvantage by altering the 
environment in a way that promotes economic equality (Currie, 2011). Thus, the FOH remains important because it suggests that it may be possible to counter-balance forces leading to greater inequality (such as skill biased technical change) with investments in pregnant women, children, and their environments broadly defined. ${ }^{2}$

In addition to surveying studies that focus on shocks that occur while the child is in utero, this review considers shocks in early childhood. Angrist and Pischke (2010) herald a "credibility revolution" in which clear a priori definitions of treatment and control groups combined with time-series variation in environmental conditions help to generate sharp predictions. The FOH hypothesis lends itself to "severe tests" (Dinardo, 2007) given that the in utero period is very well defined, and children subjected to an external shock in utero can often be compared to similar children born a little earlier or later, who escaeped the shock. The beginning and ending dates of the period of "early childhood" are less well defined than the period in utero making it somewhat more difficult to find clean "natural experiments." It is nevertheless possible to employ compelling identification strategies and we feel the majority of papers discussed in this review employ compelling research designs.

In view of the large number of relevant studies, we organize the review around a series of "handbook" style tables that we present in the supplemental file (which can be found using the link in the abstract page). In lyric opera fashion, the tables briefly summarize each study's highlights. We also report the datasets used, sample sizes, the empirical strategy employed, main results obtained, and any heterogeneity by subgroup in the tables. We have also tried to express

\footnotetext{
${ }^{2}$ In describing "Six examples of the Long-term Benefits of Anti-Poverty Programs", the White House's Council of Economic Advisers summarized recent research in this literature by economists, noting:

Economists have traditionally argued that anti-poverty policy faces a "great tradeoff" famously articulated by Arthur Okun - between equity and efficiency. Yet, recent work suggests that Okun's famous tradeoff may be far smaller in practice than traditionally believed and in many cases precisely the opposite could be the case.
} 
the main effects both as a percent with respect to the outcome mean (when the outcome mean was provided in the paper) and in terms of a standard deviation (when the outcome's standard deviation was provided). To some extent, reporting estimates in $\%$ and in SD facilitates the comparison of the effects across studies when these focus on a similar outcome (e.g., test scores).

Consistent with the broader trend in economics, many of these papers pay particular attention to the use of large-scale administrative datasets. Beyond reducing measurement error and recording additional outcomes, the use of administrative data can help mitigate problems of selective attrition from surveys and the large sample sizes contribute statistical power to detect milder treatments. These tables largely speak for themselves, so rather than walk through them, we focus in the text on a few studies from each table in an attempt to draw some general lessons from the existing literature and to identify promising areas for future research.

We begin by providing a conceptual framework for our review in Section 1. This framework emphasizes the child's human capital accumulation process and parent's optimal investment decisions in the presence of in-utero and early childhood shocks given production functions and budget constraints. The framework can be used to elucidate potential pathways that underlie the empirical findings that we observe in the literature. Section 2 then provides an overview of the literature on the importance of "mild" shocks in the early years. In addition to new evidence about the wide range of factors that matter to child development, an important theme that emerges is that there is often considerable heterogeneity in the effects of specific shocks. Some of the heterogeneity in the effects of shocks may be due to parental responses that either exacerbate or mitigate the effects. Hence, we will also consider the evidence documenting some of these responses and their impacts in Sections 3. 
In addition, a small but growing literature exploits situations where there are "two shocks" in order to either separately identify the effects of initial shocks and responses to them, or to investigate potential interactions between various types of shocks. Since this is an interesting and novel development that resonates with the theory of capacity formation (Heckman, 2007), some of these studies are highlighted in Section 4.

As discussed above, economists are beginning to investigate policy responses to the FOH. Recent contributions to this literature are reviewed in Section 5. A striking feature of the most recent literature is that the growing accessibility of administrative data has allowed researchers to conduct policy evaluation by linking current adult outcomes with past "exposures" to policies in a way that was not possible previously.

One practical difficulty with this approach is that it takes many years to see the effects of fetal or early childhood shocks on adult outcomes while timelines for policy decisions are typically much shorter. Thus, one of our conclusions is that it would be extremely useful to know more about the "missing middle" years, and whether long term effects can be predicted using indicators in early and middle childhood. This question is explored in Section 6. We summarize our impressions of the literature and its future directions in Section 7.

Because the literature is growing so rapidly and in so many directions, this review will not do justice to it all. To make the review more tractable we focus mainly on studies that appeared after our previous reviews were published, and we do not do justice to the "disaster" literature which relies on lethal natural catastrophes such as famines, pandemics, wars, and hurricanes, as natural experiments. Although these papers were very important in the emergence of the $\mathrm{FOH}$, most economists now accept that disasters early in life are likely to have negative 
long-term effects on survivors, i.e., that shocks which are "extreme enough" are likely to have persistent effects. Moreover, the fetal origins perspective will never be pivotal in a cost-benefit analysis of measures designed to forestall such disasters. ${ }^{3}$ Even without the benefit of the recent economic and scientific evidence on the $\mathrm{FOH}$, those suffering disaster often acted in a way to shield pregnant women and young children (such as by giving them larger food rations in a famine). Third, the long term effects of events that involved high mortality can be difficult to discern given the possibility of mortality selection. If the individuals most vulnerable to catastrophe die, then the remaining population could possibly be stronger on average. Selection can be a particular problem when risk of death is higher for groups with lower socioeconomic status, as it often is.

We will also neglect most of the research on conditional cash transfers, in part because it have been reviewed elsewhere (see for example, Fiszbein and Schady, 2009). In addition to these deliberate omissions, we will undoubtedly omit important studies by mistake, given how active the research area has become.

\section{Section 1: Conceptual Framework}

Following Heckman (2007), the production technology we consider is a two period Constant Elasticity of Substitution (CES) function:

$$
h=A\left[\gamma\left(\bar{I}_{1}+\mu_{1 g}\right)^{\phi}+(1-\gamma)\left(I_{2}+\mu_{2 g}\right)^{\phi}\right]^{1 / \phi}
$$

\footnotetext{
${ }^{3}$ We do not intend to suggest that insight and nuance cannot be gleaned from the analysis of such events. For example, Anttila-Hughes and Hsiang (2013) study natural disasters and show that the short-run mortality effects are followed by arguably more important future disinvestments which occur with a lag and kill girls.
} 
where $h$ denotes health or human capital as assessed after childhood, A represents factor productivity, and $\bar{I}_{1}$ and $I_{2}$ are the investments made in the first and second periods (e.g., parental investments). The first childhood period is denoted with subscript 1 (e.g., in utero) and the second period of childhood (e.g., preschool years) with subscript $2 .{ }^{4}$ A bar superscript indicates that the first period investment is already set, and what is under consideration is the second period investment.

Following Currie and Almond (2011b), we assume that $\mu_{1 g}$ is an exogenous shock to first period investments (e.g., during pregnancy) and $\mu_{2 g}$ is an exogenous shock to second period investments (e.g., during pre-school years). The $g$ subscript follows from the fact that exogenous shocks in observational studies typically appear at the group level, whereas the other components of investments, $\bar{I}_{1}$ and $I_{2}$ may vary at the level of the individual child. In general, we will consider the effect of investment shocks $\left(\mu_{1 g}\right.$ and $\left.\mu_{2 g}\right)$ holding fixed the child-specific investments during the first period of childhood. If we also hold fixed second period investments (i.e., $\bar{I}_{2}$ instead of $I_{2}$ ), then we might consider impacts from shocks on $h$ to be "biological" (Royer, 2009). The parameter $\gamma$, where $\gamma \in[0,1]$, represents the weight each childhood period receives in the production of adult health (or more generally, adult human capital). ${ }^{5}$ The parameter $\phi$, where $\phi \in(-\infty, 1]$, denotes the extent to which investments in different periods are substitutes or complements, often a key question determining the efficacy of interventions.

We assume that parents make the investment decisions for their (only) child. Investments are costly, and are valued insofar as they improve $h$. The effects of investments on

\footnotetext{
${ }^{4}$ For simplicity, we consider only two childhood periods, however, this framework can be extended to any number of periods (Heckman, 2007).

${ }^{5} \gamma$ is the "capacity multiplier" in Heckman (2007).
} 
$h$ are traded off against parental consumption, i.e., parents maximize their utility, $U=U(C, h)$, which is increasing in both arguments. Parents have a budget constraint (expressed in monetary units) of:

$$
Y=p_{C} C+p_{I} I_{1}+p_{I} I_{2} /(1+r)
$$

where $\mathrm{Y}$ denotes family income, $\mathrm{p}_{\mathrm{c}}$ and $\mathrm{p}_{\mathrm{I}}$ are the market prices of consumption and investment, and $\mathrm{r}$ is the interest rate. We assume a Cobb-Douglas utility function of the form:

$$
\mathrm{U}=(1-\alpha) \log \mathrm{C}+\alpha \log \mathrm{h},
$$

and consider how the production technology can shape the observed investment response. In particular, we consider two "extreme" production technologies which have polar opposite predictions for the investment response. The first special case is one of perfect substitutability of investments. If $\phi=1$, then production technology simplifies to:

$$
h=A\left[\gamma\left(\bar{I}_{1}+\mu_{1 g}\right)+(1-\gamma)\left(I_{2}+\mu_{2 g}\right)\right]
$$

and optimizing parents set:

$$
\delta U / \delta C^{*}=\delta U / \delta h \cdot \delta h / \delta I_{2}^{*}(1+r) / p_{I} .
$$

So under this scenario:

$$
\begin{gathered}
\frac{1-\alpha}{C^{*}}=\frac{\alpha}{h} A(1-\gamma)(1+r) / p_{I} \\
\frac{1-\alpha}{y-p_{I} \bar{I}_{1}-p_{I} I_{2}^{*} /(1+r)}=\frac{\alpha(1-\gamma)(1+r) / p_{I}}{\gamma\left(\bar{I}_{1}+\mu_{1 g}\right)+(1-\gamma)\left(I_{2}^{*}+\mu_{2 g}\right)} \\
I_{2}^{*}=\alpha\left(y-p_{I} \bar{I}_{1}\right)(1+r) / p_{I}-(1-\alpha)(\gamma /(1-\gamma))\left(\bar{I}_{1}+\mu_{1 g}\right)-(1-\alpha) \mu_{2 g}
\end{gathered}
$$




$$
\frac{\delta I_{2}^{*}}{\delta \mu_{1 g}}=-\frac{(1-\alpha) \gamma}{(1-\gamma)}<0
$$

If the ${ }^{\mu g}$ shock is positive (e.g., prenatal Food Stamps), then optimized postnatal investments fall in response. If ${ }^{\mu_{1 g}}$ is negative (e.g., prenatal stress), then postnatal investments increase in response. That is, period 2 investments are compensatory. When investment responses are compensatory, reduced form analyses of the impact of $\mu_{1 g}$ will tend to understate biological effects (Royer, 2009).

Following Heckman (2007), we now consider the opposite extreme of perfectly complementary investments:

$$
h=A \operatorname{Min}\left[\gamma\left(\bar{I}_{1}+\mu_{1 g}\right),(1-\gamma)\left(I_{2}+\mu_{2 g}\right)\right] .
$$

Now optimizing parents $^{6}$ set:

$$
\gamma\left(\bar{I}_{1}+\mu_{1 g}\right)=(1-\gamma)\left(I_{2}^{*}+\mu_{2 g}\right)
$$

so

$$
\frac{\delta I_{2}^{*}}{\delta \mu_{1 g}}=\frac{\gamma}{1-\gamma}>0 .
$$

The period 2 investment response is now reinforcing. Attempting to ameliorate a negative prenatal shock is completely ineffective, so it is optimal to match period 1 investments (subject to weighting by $\gamma$ ) but consume the rest.

The takeaway from these two examples is that whether parents reinforce or compensate shocks can depend on the production technology. Above, we have assumed an "intermediate" substitutability in parental preferences between consumption and their child's $h$ : Cobb-Douglas.

\footnotetext{
${ }^{6}$ For whom period 1 investments are "low", i.e., $\delta U / \delta C^{*}<\delta U / \delta h \cdot \delta h / \delta I_{2}^{*}(1+r) / p_{l}$.
} 
By a similar argument, the substitutability of consumption and child outcomes $h$ will also govern the response to early childhood shocks. That said, we might suspect that parameters of parental preferences are particularly difficult to modify.

We might think that in addition to low income, y, poor families face restricted access to production technologies. Given a productivity factor $A^{\prime}<A$ for disadvantaged families, we would see worse child outcomes for equivalent income and investments. It is also possible that poor families have different values of $\gamma$ and ${ }^{\phi}$, which would generate more nuanced predictions for investments and child outcomes.

There have been few attempts to estimate this underlying production function (1), in order to directly measure the key parameters $\phi$ and $\gamma$, presumably because of the detailed data necessary and the strong assumptions which must be made in order to render the production function simple enough to be estimable (Cunha and Heckman, 2008; Cunha, Heckman, and Schennach, 2010). However, arguably this underlying framework serves to motivate, guide, and interpret the more reduced form and observational work that is discussed below.

The framework also lays bare the multiple mechanisms that can underlie a given empirical result. For instance, if we observe that parents do or do not make compensating later life investments in a child who suffered from an early life shock, is this because of parental preferences, budget constraints, ${ }^{7}$ or the production function they are facing? Answering this question is important because without a knowledge of the mechanisms and responses, a policy designed to address this issue will be a shot in the dark.

\footnotetext{
${ }^{7}$ See page 1330 (bottom) and footnote 7 of Almond \& Currie (2011b).
} 
Similarly, given the different pathways through which a child's outcomes can be affected, it is not surprising to see pronounced heterogeneity in the effect of many shocks by parental education, income, and other indicators of socioeconomic status (such as race or gender in some contexts). Subgroups may be more or less exposed to correlated shocks that interact with the "primary" shock considered, either to magnify or to dampen its effect. And even within finelysliced subpopulations, the same group-level shock can yield varying individual exposures. For example, a house that is airtight may let in less air pollution than a neighboring house that is drafty. Third, families have differential access to knowledge and resources that can be used to offset the effects of negative shocks. For instance, while some individuals may have access to credit markets or savings, others may be credit constrained. They may also have different preferences for such intervention. For example, in communities where gender discrimination is the norm, parents may not endorse interventions targeted to girls. Finally, children of low socioeconomic status may simply be located at a steeper portion of the production function, yielding a larger effect of a shock of any given size (Almond and Currie, 2011b).

Even our focus on the missing research on the "middle years" can be seen as a response to the difficulties involved in understanding the underlying production function for human capital. If it could be shown that outcome measures in middle childhood satisfied the "exclusion restriction" (that early childhood impacts adult outcomes only through observed outcomes in the middle years), this would greatly simplify the data requirements necessary to estimate a structural production function.

We should acknowledge that our stylized framework does not lend itself to considering dynamic complementarities -- the idea that "skill begets skill," or alternatively that stocks of 
capacities acquired by period t-1 may make investment in period t more productive (Heckman, 2007). Nor does it do justice to "self-productivity" (Heckman, 2007) - which includes the idea that a given dimension of capacity may also affect the accumulation of another, distinct dimension. $^{8}$ For example, cognitive capacity might promote health (or vice versa). Were we to "force" dynamic complementarities into (1) and consider $\frac{\delta h}{\delta \mu_{2 g}} / \frac{\delta h}{\delta \mu_{1 g}}$, for instance, one would find that the interaction of such shocks is always positive (which departs from what some of the recent empirical literature finds as discussed below). Additionally, dynamic complementarities are defined by Heckman (2007) in terms of the return to investments and how they vary with the baseline stock, which is absent from our stylized model. Thus, we will not attempt to model dynamic complementarities here but merely reiterate Heckman's (2007) definition, namely:

$$
\delta^{2} f_{t}\left(p, \theta_{t}, I_{t}\right) / \delta \theta_{t} \delta I_{t}
$$

where $f$ is monotone increasing in its arguments, twice continuously differentiable, and concave in $I, p$ represents parental capabilities, and $\theta_{t}$ represents (a vector of) child capabilities. Heckman assumes that dynamic complementarities are positive. With instruments for both the baseline stock of human capital and for endogenous subsequent investments, we could shed light on the magnitude of dynamic complementarities without making assumptions about their sign or functional form.

In practice, it is often not empirically possible to distinguish between dynamic complementarities, self-productivity, and the possibility that parents (or society) invest more (or less) in children with higher baseline stocks of human capital in unobserved ways (e.g., Malamund, Pop-Eleches, and Urquiola, 2016). Nevertheless, distinguishing among these

\footnotetext{
${ }^{8}$ Along with "mechanical" effects on the same dimension.
} 
alternatives remains conceptually important because the source of heterogeneity in the dynamic effects of shocks has implications for the effectiveness of remediation, and specifically, whether investments later in childhood can reduce or eliminate damage originating from the prenatal or early childhood period. For instance, if a child has cognitive difficulties as a result of being premature, a parent may respond by spending more time with the child, reading to them and assisting with homework. We may wish to examine the effects of these interventions, but the interventions themselves are endogenous to the child's state. Moreover, while we would like to be able to consider each potential investment as a stand-alone intervention, in reality many aspects of the environment are in flux at any point in time, and different types of investments may complement or substitute for each other. A few studies that attempt to address dynamic complementarities are discussed in Section 4 below, and illustrate the challenges researchers face. We begin below with the simpler case of single shocks experienced in early childhood.

\section{Section 2: Make Mine Mild}

Events and circumstances that are commonly experienced can have lasting effects on children's trajectories. For example, there is growing consensus that relatively mild nutritional deprivation at critical periods can seriously impair fetal and child development. In terms of our conceptual framework, both $\delta h / \delta \mu_{1 g}$ and $\delta h / \delta \mu_{2 g}$ may be sizable, even when the shock considered is small in magnitude relative to total investments or short in duration. Critically, "mild" prenatal shocks are much more common than extreme ones like famine. Table 1 summarizes much of the recent literature about mild shocks, which are divided into several categories including: nutrition, stress, disease, pollution, weather shocks, and alcohol and tobacco. The last column reports on heterogeneity in the estimated effects on different groups, a 
format that is followed in all the Tables that follow. With some exceptions, these papers aim to capture the biological effect of early-childhood shocks, implicitly assuming that second period investments are unresponsive to the shocks and fixed $\left(I_{2}=\bar{I}_{2}\right)$.

\section{a) Nutritional Shocks}

Panel A of Table 1 summarizes some of the recent literature on nutrition-related shocks. Fasting is of broad interest as roughly three-quarters of the world's 1.6 billion Muslims spent some portion of the in utero period during Ramadan. ${ }^{9}$ Almond and Mazumder (2011), Almond, Mazumder, and Van Ewijk (2015), Hoffman (2014), and Greve, Schultz-Nielsen, and Tekin (2015) all study the effects of Ramadan fasting during pregnancy. Ramadan cycles through the calendar, enabling the effects of Ramadan fasting to be separated from seasonal variation in nutrition. Moreover, most people break their fast at sun down so that the fasting is only for a limited period of time during the day. Nevertheless, this mild and brief nutritional deprivation appears to have effects on sex ratios (reducing the number of boys who appear to be more likely to be miscarried). For example, there are large effects on sex ratios among children of Arabian descent in Michigan. Perhaps surprisingly in view of relatively modest effects on birth weight, prenatal Ramadan exposure is estimated to have pronounced effects on adult outcomes in a wide variety of settings (e.g., Uganda, Iraq, Indonesia, England, and Denmark), including to educational attainment, test scores, adult anthropometrics, mental disability, and wealth measures.

\footnotetext{
${ }^{9}$ Almond, Mazumder, and Van Ewijk (2015) speculate that meal skipping, dieting, and morning sickness may all exert similar effects in non-Muslim populations. For example, Almond, Edlund, Joffe, and Palme (2016) find that severe morning sickness also reduces the likelihood of male birth in Sweden.
} 
Likewise, positive nutrition-related shocks can also have substantial effects even when relatively mild. For example, Linnemayr and Alderman (2011) examine nutritional supplementation for pregnant women and 0 to 3 year old children in Senegal and find that supplementation during pregnancy has a significant effect on the weight-for-age of toddlers, but that post-birth supplementation had little impact, suggesting the uniqueness of the in utero period (a common refrain in the literature). Two papers by Feyrer, Politi, and Weil (2013) and Adhvaryu et al. (2016) build on Field, Robles, and Torero's (2009) ground breaking study of the effects of iodine deficiency in Kenya. The more recent studies use historical data about the rollout of iodine fortification in the U.S. Because the rollout took place at different times in different places, it is possible to identify the effect of early exposure and to show that it improved both female labor force participation and the probability that male World War I recruits were assigned to the Air Force (a marker for ability). They thus provide additional evidence that relatively mild nutritional deficiency can have large negative long term effects even in otherwise high-resource settings.

Adhvaryu et al. (2016) also analyzes measures of parental investments in children, albeit coarse ones, and find evidence that postnatal investments responded to the shock. In particular, they argue that postnatal vaccinations and breastfeeding behaviors reinforced the prenatal shock, i.e., $\frac{\delta L_{2}^{*}}{\delta \mu_{1 g}}>0$, so their reduced form estimates overstate the biological effect. As discussed above (and further in Almond and Currie, 2011b), to the extent that period 1 and period 2 are complements, there are stronger tendencies for parents to reinforce endowment shocks.

Ludwig, Rouse, and Currie (2013) show that maternal weight gain during pregnancy predicts childhood obesity in the context of sibling fixed effects models. This study is based on 
birth certificates for several entire cohorts of children born in Arkansas, which were linked to "body mass index (BMI) report cards" issued by the schools. It is one of an increasing number of studies that show how new access to large-scale administrative data sets can shed light on FOH questions.

Fitzsimons and Vera-Hernandez (2014) use a novel instrumental variables strategy for postnatal nutrition, focusing on non-C-section births to U.K. women. They note that mothers of infants born on weekends are less likely to receive breastfeeding instruction, and are correspondingly less likely to go on to breastfeed. Using this variation, they find large effects of breastfeeding on cognitive development. However, the IV approach involves strong exclusion restrictions, in this case that there is nothing else about being born on a weekend (or about having a scheduled C-section) that might lead to poorer outcomes (such as different preferences, inferior nursing care, or less access to specialists).

As a group, these studies support the hypothesis that relatively ordinary variations in nutrition (positive and negative) that are within the experience of many contemporary families even in rich countries like the U.S. and the U.K., have the potential to impact children health both at birth and in the longer term.

\section{b) Prenatal Maternal Stress}

Panel B of Table 1 focuses on the impact of maternal stress during pregnancy on fetal outcomes. While the idea that excessive stress has negative health effects is widespread, it is difficult to assess. Cortisol, the most common biometric measure of stress, is not available in most health datasets and also varies widely over the course of a day, which even longitudinal cortisol data do not solve per se. In the absence of a direct measure of stress, the most common 
approach in the literature is therefore reduced form: Evaluating whether an exogenous event that is likely to have caused maternal stress can be shown to have affected children.

Currie and Rossin-Slater (2013) identify women in Texas who lived in the announced potential path of major hurricanes during pregnancy. It is important to note that most of these women were not in the end affected by the hurricane, so this is not a disaster study in the usual sense in that it is possible to separate the effect of stress from the direct economic or health effects of the event. They highlight an issue that often arises in the fetal effects literature, which is that infants with longer gestations are more likely to have been exposed to any periodic shock because they have a longer exposure window. Since infants with longer gestations are healthier, other things being equal, this mechanical relationship tends to bias the estimated effect of shocks towards zero. They use a sibling fixed effects framework to compare affected to unaffected children and they address maternal mobility, an issue that frequently arises in a sibling fixed effects framework. The problem is that mothers may well respond to a shock by moving. In that case, changes in locational characteristics or exposure between the siblings are endogenous to the shock. This issue is addressed by instrumenting actual exposure with measures of "potential exposure" created by assuming that mothers stay in the same place that they were first observed, and that all gestations last exactly nine months. This counterfactual exposure is in fact highly correlated with actual exposure because most mothers do stay in the same place, and most gestations do last nine months. They conclude that stress increases the probability of an abnormal condition of the newborn, but they found no effects on the incidence of low birth weight or gestation length, two of the more common measures of fetal health. 
Persson and Rossin-Slater (2016), and Quintana-Domeque and Rodenas-Serrano (2016) study the effect of more severe emotional shocks including, the death of a family member in Sweden, and terrorist attacks in Spain, respectively. The former uses Swedish registry data to follow affected children up to age 30. An important innovation of their study relative to some earlier work on the same question is that they compare mothers who lost a family member while pregnant, to mothers who lost a family member in the year after birth. Since families of lower socioeconomic status are more likely to lose family members, and since losing a family member could well have an economic impact, this design is cleaner than comparing mothers with a death in the family to mothers without such an event. While the effects on birth weight are small overall, they appear to be concentrated in the lower tail of the distribution, with a $20 \%$ increase in the incidence of low birth weight (birth weight less than 2500 grams). In a second contribution, they are able to follow affected infants into adulthood, and they find negative effects on mental health outcomes measured using prescription drug data. For instance, affected individuals are 23\% more likely to use ADHD medication, and 9\% more likely to use antidepressants as adults. Quintana-Domeque and Rodenas-Serrano also find small but significant effects of terrorist attacks in Spain on overall birth outcomes.

Lee (2014) asks whether the grandchildren of women who suffered a severe stress are less healthy? This is a particularly exciting direction for future work, given that thus far, there is not a great deal of research on intergenerational effects of in utero shocks in humans, although they are known to exist in animal models. In this case the initial shock is was a massacre of civilian demonstrators by the civilian military. He finds small but significant effects on the incidence of low birth weight and prematurity in the grandchildren, with the largest impacts for grandmothers who suffered the shock during the second trimester that the mothers were in utero. 
Aizer, Stroud, and Buka (2016) have made an exceptional contribution to this literature because the data they use (which was collected by a consortium of perinatal centers in the 1960s) actually includes measured stress during pregnancy using cortisol. The data set includes a large number of sibling pairs, so that it is possible to conduct mother fixed effects analyses. They find that infants exposed to higher cortisol levels during pregnancy have up to 1 year less school at age 7 than their siblings, indicating that they have been delayed in starting school or held back. Given rich background information on the mothers, this study is also able to ask which infants are most affected by higher maternal stress levels? They find that children born to less educated mothers suffer larger impacts of exposure to a given cortisol level, suggesting that perhaps there were fewer resources available to buffer the impact ex-post.

We have included Aizer's (2011) study of the impact of assault (overwhelmingly due to domestic violence) in this Section of the table even though domestic violence can have direct effects on fetal health in addition to causing maternal stress. Our justification for doing so is that domestic violence is quantitatively important and vastly understudied as a source either of stress or physical injury. The study is based on California hospital discharge data linked to birth records. Variation in the probability of assault is induced by the strengthening of laws against domestic violence, which occurred at different times in different California counties. She finds that domestic violence has a large negative effect on birth weight. Since women of lower socioeconomic status are more likely to be assaulted, violence is therefore an additional cause of disparities in birth outcomes.

\section{c) Infectious Disease}


Panel C of Table 1 deals with recent evidence about the effects of disease. Some diseases that have only mild effects in adults are known to have devastating effects on a developing fetus (e.g., Rubella, Zika), while others, like pandemic influenza killed millions and have also been shown to have effects on fetuses in utero. Recent studies focus on the related questions of whether milder diseases can have serious effects; whether the effects of early life exposure to disease are long-lasting; and whether there are spillover effects of disease eradication to children who were not directly targeted. The studies we summarize cover a wide range of settings, from impoverished areas of developing countries, to the historical U.S., to modern Denmark.

The studies by Baird, Hicks, Kremer, and Miguel (2016) and Oizer (2014) build on the famous "worms" paper of Kremer and Miguel (2004) in which the authors investigated the effect of giving children de-worming medication on school attendance and on whether neighboring children were infected with parasites. The new studies ask (respectively) how the effect of deworming affects outcomes of affected children 10 years later, and whether other children benefited from the deworming of their neighbors. Significant and positive effects of deworming are found on virtually all outcomes examined. Unfortunately Oizer does not examine exactly the same outcomes as Baird et al., so it is hard to compare the effects on index children to those on their neighbors, but in keeping with the original paper, deworming initiatives definitely appear to be very cost-effective.

Bhalotra and Venkataramani (2013) and Beach et al. (2016) focus on water borne diseases in Mexico in the 1990s, and in early 20th century America, respectively. The former examine the effect of a clean water reform in Mexico in 1991, which reduced the incidence of water borne diseases, including diarrhea, one of the most common causes of mortality and 
morbidity among infants. Beach et al. (2016) use typhoid mortality rates as a proxy for water quality. Bhalotra and Venkataramani find significantly positive but quite small effects of the reduction in water-borne diseases on test scores at ages 9-15. These estimates may understate the effect of clean water given improved survival of the weakest infants, who may end up with low test scores for reasons unrelated to water-borne disease. The Beach et al. estimates appear to be larger: They estimate that moving from the top of the typhoid distribution to eradication would increase educational attainment in surviving children by $1 / 3$ of a year and increase earnings by $4 \%$. This larger effect is unsurprising given that typhoid is at the extreme end of potential severity of water-borne contaminants and many of the contaminants addressed by the water campaigns studied by Bhalotra and Venkataramani would have caused less severe disease. Thus, a possible interpretation is that more severe shocks have a greater impact than less severe shocks but with only two data points it is impossible to say much more about the shape of this relationship.

Venkataramani (2012) builds on work by Bleakley (2010) and others on the long-term effects of malaria. He finds large effects of malaria eradication in the birth year, consistent with those previous studies. Currie and Schwandt (2013) focus on a much milder and currently more common disease: Seasonal influenza. While Almond (2006) showed that the Spanish flu epidemic of 1918 had long lasting effects, it was a killer disease. Currie and Schwandt show that even a relatively mild disease such as seasonal influenza can have negative long term effects if a fetus is exposed at the wrong time during pregnancy. They show that in the contemporary northeastern U.S., infants conceived in May have a much higher probability of preterm delivery (and hence of low birth weight) than infants conceived at other times because they come to term 
at the height of the flu season. Moreover, the H1N1 flu season of 2009 was earlier and more virulent than usual and the spike in prematurity was correspondingly earlier and larger that year.

Schwandt (2016) and Ward and Phipps (2014) follow up on these observations by examining the long-term effects of exposure to flu in utero in Denmark and Canada, respectively. Schwandt examines rich individual longitudinal Danish registry data about women who were hospitalized with influenza and follows their children into adulthood. He finds that earnings are $10 \%$ lower for affected individuals, and that they are much more likely than others to be dependent on welfare. These long-term outcomes are driven by maternal admissions during the 2nd and 3rd trimester. Ward and Phipps (2014) exploit province-level data on influenza rates to identify the effects of exposure. They do not find any overall effect of an additional week of flu exposure during the pregnancy, but do find a small effect of additional weeks of exposure during the 1st trimester on test scores and on the probability of having a chronic condition. Given that the richness of the Schwandt data it seems that for now, the presumption should be that his conclusions about the timing of the impacts are more likely to be correct. However, the larger message is that millions of children may be harmed in utero by exposure to relatively mild diseases even in rich countries.

Bhalotra and Venkataramani (2015) examine the long-term impact of the introduction of sulfa drugs in 1937, which reduced pneumonia mortality but presumably also had positive effects reducing morbidity. ${ }^{10}$ Combining historical data with the U.S. population Census, cohorts who were exposed to sulfa drugs in their infancy attained 0.1 more years of schooling, were $1.5 \%$ more likely to graduate from high school, more likely to be employed $(0.4 \%)$, and earned higher

\footnotetext{
${ }^{10}$ An earlier paper Jayachandran, Lleras-Muney, and Smith (2010) established that the introduction of these drugs did indeed lead to large declines in mortality from causes such as infections after child birth and pneumonia. Bhalotra and Venkataramani focus on the effects of the introduction on cohorts of children at older ages.
} 
wages (1.5\%). Long-term benefits varied for African-American men who were exposed to different levels of segregation in their state of birth, suggesting that despite a strong economic climate (better early life conditions), institutional environment affects the rewards to investments in human capital.

\section{d) Pollution Exposure}

The last few years have seen an explosion of research on the effects of pollution in early life, much of which is summarized in Panel D of Table 1. Certain pollutants are well measured in developed countries, exhibit variation over time and across small areas, and have published thresholds which lend themselves to asking whether pollution below the threshold can also be shown to have an adverse effect. Moreover, many sources and types of pollution have been increasingly well documented in recent years, and have discrete beginning and ending dates (such as pollution due to industrial plant openings or closings) that assist identification.

Relative to the literature discussed in our earlier reviews, much of the newest literature focuses on documenting the long-term effects of fetal or early childhood exposures, often relying on newly available large-scale administrative data sources to track children over time. For example, Isen, Rossin-Slater, and Walker (2015) look at the effects of reductions in air pollution due to the Clean Air Acts of 1970 on the employment and earnings of adults who were affected in very early childhood. The Clean Air Acts (CAA) mandated that pollution reduction measures be implemented in counties that were above thresholds for target pollutants. Counties just below these thresholds were not required to clean up. The legislation thus lends itself to analysis using a regression discontinuity framework. In order however to examine outcomes, it is necessary to 
merge data from several large administrative data sets, some of which are held in Census data centers.

Specifically, they start with the Census Bureau's Longitudinal Employer Household Dynamics (LEHD) file, which records a worker's unemployment insurance covered earnings each quarter. The authors focus on 24 states that appear continuously in the LEHD and on individuals who were born in these states. The payoff to all this careful data work is that the authors are able for the first time to link air pollution changes around the time of birth to adult earnings and employment. They find an estimated gain of $\$ 4,300$ in earnings per person for a total of $\$ 6.5$ billion (2008 dollars) in gains.

Another focus of the literature on pollution and early childhood is to ask whether there is heterogeneity in the effects of pollution. There are many reasons to expect disparate impacts of the same potential exposures. For example, more educated people may be more knowledgeable about ways to protect themselves (i.e., have access to a different production function), or may be more likely to take measures that compensate for the harmful effects of pollution (perhaps because of looser budget constraints). They may even be more likely to move away from known pollution sources while the child is still young (Currie, 2011). Richer people may live in housing that insulates them from the effects of pollution, for example, by having houses that are more airtight, or houses that are physically located slightly further from sources such as freeways or factories.

The literature does generally find more negative effects of pollution on more disadvantaged people, whether disadvantage is defined in terms of minority race, income, or education. The only study in Table 1 that finds the opposite is Black et al. (2014) who study the effect of radioactive fallout from nuclear tests on Norwegians born in the 1950s and early 1960s. 
In this one case, they find that the effects of potential exposure are greater for the more educated, perhaps because people were unaware of the danger and more educated people were more likely to spend time out of doors (echoing earlier findings by Lleras-Muney for ozone, 2010).

Billings and Schnepel (2015) offer some evidence that the negative effects of early-life pollution exposure might actually be reversed with appropriate interventions, which can be interpreted as evidence about the substitutability of investments in different life periods. The authors show that children who were lead poisoned in Charlotte, North Carolina, and who also received an intense intervention comprised of education for caregivers, lead remediation services, nutritional and medical assessments, and other nutritional benefits from the Special Supplemental Nutrition Program for Women, Infants, and Children (WIC), experienced reductions in antisocial behavior and substantial improvements in school performance relative to peers who did not receive these services because they had slightly lower blood lead levels. Since we know that the physical effects of lead are irreversible (once deposited in the brain for example, lead tends to stay there), this result offers hope that compensation for early life insults is possible even when the physiological effects of such insults cannot be reversed.

\section{e) Weather and Climate Change}

With increasing scientific consensus about the reality of human induced global warming, economists have responded to concerns about the short and long term effects of climate change on young children. These studies generally extrapolate from what is known about the effects of short-term variations in weather, including periods of high temperature, variations in the amount of sunlight, drought, or flooding. These studies are summarized in Panel E of Table 1. Of these papers, only the one by Wernerfelt, Slusky, and Zeckhauser (2016) is arguably really about 
weather effects per se. The authors find that exposure to sunlight in utero is associated with lower incidence of asthma in affected U.S. cohorts, a result that they attribute to the effect of vitamin D on lung development in utero.

The remaining papers find effects that may work through economic mechanisms as well as through biological pathways. In terms of the Section 1 framework, these papers are implicitly considering the optimized response of $h$ to $\Delta Y$ (changes in parental income). Given the budget constraint in Section 1, a negative income shock would reduce investments in children in both period 1 and period 2 so as to equate marginal utilities of parental consumption and investing in children (at a higher level). If the marginal utility of consumption increases substantially with reduced consumption, child investments will need to be reduced even more. This may be particularly true at low baseline levels of consumption.

Several studies focus on weather shocks in rural populations where conditions outside the norm may lead to income losses by affecting crop yields; this may be a major pathway through which weather affects child outcomes. For example, Agüero (2014) examine the effect of high temperatures in a nationally representative sample of Mexicans, and find that higher temperatures during early childhood are associated with lower adult height. The effects are greater in poorer districts which could be either because people in those areas are less able to shield themselves through, for example, air conditioning (i.e., a biological effect working through the production function), or because many poorer parts of Mexico are agricultural and heat may cause crop losses (an economic effect working through the budget constraint). One limitation of the work to date is that it is often impossible to distinguish between these pathways. 
The remaining papers in Panel E deal with fluctuations in rainfall, which are probably even more likely to lead to crop loss, and thus to affect outcomes primarily through economic channels. The Shah and Steinberg (2016) study is interesting in that it finds that drought has a positive effect on children's educational attainment in India. They explain this finding by arguing that in India, developments that prevent children from working in the fields may benefit their education. In the context of the model sketched above, one would have to add children's potential earnings to the budget constraint and allow weather to affect the market wage for children's labor (and thereby the opportunity cost of schooling investments) in order to capture this effect.

\section{f) Effects of Alcohol and Tobacco on Fetal Development}

Finally, Panel F of Table 1 considers three recent papers discussing the effects of alcohol and tobacco control policies on fetal development. While it is well known that alcohol and tobacco can harm the developing fetus, these studies focus on heterogeneity in the effects of policy, and on longer-term effects. Von Hinke, Kessler, and Scholder et al. (2014) find longterm effects of maternal alcohol consumption during pregnancy on children's test scores up to age 16 in data from the Avon Longitudinal Study. This study uses genetic variation in the mother as an instrument for alcohol consumption. Causal interpretation of an alcohol effect requires the assumption that the genetic variation in question has no effect other than through maternal alcohol consumption, which is questionable since currently scientists have relatively little understanding of the multiple pathways through which an observed genetic variation may impact a person. That is, even if we knew with certainty that a particular gene was associated with alcoholism, it might also be independently associated with cognitive problems in the 
offspring. An additional concern about the use of genetic data as instrumental variables is that genetic effect sizes are often very small and therefore raise possible concerns about weak instruments.

Using register data from Sweden, Nilsson (2015) investigates the long-term effects of a policy that permitted strong beer sales in grocery stores, which resulted in a temporary and sharp increase in access to alcohol among young people. He finds that cohorts affected in utero early in pregnancy had $24 \%$ lower earnings at age 30 , as well as lower cognitive, non-cognitive, and educational outcomes. Effects were particularly concentrated on males and among children from low-income families. Boys were also more likely to be premature or spontaneously aborted than girls. In terms of equation (1), Nilsson (2015) floats the possibility that boys and girls have different values for $\phi$.

Bharadwaj, Johnsen, and Loken (2014) study the effect of smoking bans in Norway. The authors are able to identify mothers who worked in bars and restaurants while pregnant. They find significant effects on health at birth and also on adult income at age 28 , but the effect of the reform is much stronger for mothers who were smoking at the start of the pregnancy, suggesting non-linear effects of tobacco exposure.

Simon (2016) examines the effects of changes in state-level tobacco taxes in the U.S. on maternal smoking and child health and finds that higher taxes were associated with fewer days absent from school, and reductions in the utilization of medical care, as well as with $16 \%$ fewer asthma attacks. These effects are much greater for the least educated mothers. Barreca and Page (2015) use a similar design to consider state-level changes in minimum legal drinking age laws 
and find improvements in birth outcomes among affected cohorts of women. Their estimates are also suggest improvements in the survival of black infants to term.

An economic model of a parent's choice to use alcohol or tobacco while pregnant is complicated by the fact that while in the short-term the parent trades off utility from their own consumption against the investment in a child's health, their actions also directly affect the return to future investment in child health. That is, future investments are likely to be less productive if the child is damaged by fetal alcohol syndrome, for example.

\section{Section 3: Parental Investments}

The evidence in Section 2 shows that relatively mild shocks can, if delivered at the right or wrong time, have lasting positive or negative impacts on the developing fetus and young child. The question arises then as to whether there are parental investments that can mitigate the effects of negative shocks. Conceptually, this question centers on the parameters of the CES production function $\phi$ and $\gamma .{ }^{11}$ Knowing that period 1 investments have a large effect on $h$ per se tells us relatively little about the effectiveness of period 2 investments, including whether damage from a period 1 shock can be remediated by additional period 2 investments (whereas knowing $\phi$ and $\gamma$ would take us closer).

A related question is how parents respond to positive or negative shocks to one of their children: Does $I_{2}^{*}$ change in response to $\mu_{1 g}$ ? Framed this way, the question does not require assumptions about the production technology for $h$ or parental preferences. That said, various underlying concepts from the model will govern any observed investment response. These include parents' preferences (for instance, does the parent wish to equalize outcomes or to

\footnotetext{
${ }^{11}$ Additionally, it depends on the relative sizes of $\bar{I}_{1}$ and $\bar{I}_{2}$. See Section 2.1.1 in Almond and Currie (2011b)
} 
maximize the total productivity of their offspring), and the constraints that they face. ${ }^{12}$ For instance if a parent cannot afford the cost of intervening to help a disabled child, but can afford basic investment in a non-disabled sibling, then their choice may well be obvious. If many parents are constrained in their investments, then social investments may have an important impact on parent's choices by changing the productivity and cost of their own investments. Thus, distinguishing between behavior due to preferences and behavior due to constraints can be a key input to intelligent policy responses. Moreover, as Heckman (2008) points out, it may be the case that timing matters. The productivity of current investments may depend in important ways on whether past investments have taken place.

Table 2 summarizes some of the recent literature on parental investments. Hsin (2012) was one of the first papers to consider that parental investments in their young children may reflect not only preferences, but also constraints. Using sibling fixed effects models and employing data from the Panel Study of Income Dynamics (PSID), she showed that college educated mothers compensate low birth weight children (i.e., invest in order to try to equalize outcomes) while less educated mothers tended to concentrate resources (such as reading, playing, and doing hobbies) on higher birth weight children. A limitation of her study is that the number of low birth weight children with low birth weight siblings is quite small in the PSID so the results are suggestive rather than definitive about the behavior of U.S. parents.

Breining et al. (2015) find evidence consistent with parents trying to equalize outcomes between siblings. They use Danish registry data and examine children whose siblings were either

\footnotetext{
${ }^{12}$ The returns to investment are governed by the elasticity of substitution of investment made at different stages of childhood. These returns have an impact on whether parents compensate versus reinforce, whatever their preferences are. For example, if a parent wants to compensate, but there are no suitable investments available or their return is low, then he or she will might well choose to invest in another child which would have the effect of reinforcing differences.
} 
just above the 1500 gram threshold used to classify children as very low birth weight or just below it. Children just below the threshold were found to receive more care and be healthier subsequently (as in Almond, Doyle, Kowalski, and Williams, 2010). The novel finding is that their siblings also do better in school, which suggests that medical intervention for the very low birth weight child benefitted all the children in the family. One interpretation of this result is that parents would otherwise have sacrificed the well-being of the healthy children in order to focus on the more vulnerable child. Alternatively, however, shocks to one child may work through the budget constraint to affect other children even in a rich country like Denmark where most medical care would be paid for by the state.

Akee et al. (2015) investigate the effects of a casino opening on the Eastern Cherokee reservation which resulted in an exogenous income transfer to tribal households. They find that parents reacted to the transfer by investing more in children who had lower levels of mental health and "worse" personality traits. This result seems to reflect preferences for equal outcomes - although the mechanism is a change in the budget constraint, the parent has a choice about which child to spend the "extra" money on. On the other hand, several studies in developing countries (Yi et al., 2014; Adhvaryu and Nyshadham, 2016) find evidence consistent with parents reinforcing initial differences between children which could reflect either preferences, $\phi$, or budgetary realities.

Two studies of gender differences in investments also find opposite results for developing and developed countries. Bharadwaj and Lakdawala (2013) focus on India, China, and Bangladesh and find that mothers pregnant with a boy get more prenatal care and that boys are more likely to receive tetanus shots after birth. One only sees the difference in prenatal care 
among mothers who had an ultrasound and so presumably know that they are carrying boys. However, in Canada, the U.S., and the U.K., Baker and Milligan (2016) find that parents of children aged 0 to 3 put more time into girls and that this time investment can explain as much as a third of the gender gap in reading scores in the early grades. It is possible that this pattern reflects mother's preferences for girls if mothers are the primary caregivers.

From this brief description of a number of studies, it should be apparent that there is no simple answer to the question of whether or why parents compensate or reinforce differences between their children. ${ }^{13}$ It does seem that parents are more likely to reinforce differences in low resource settings, suggesting that the observed behaviors are at least partially a response to binding budget constraints in many instances.

The discussion above assumes that parents are making informed choices about investments in their children. Dizon-Ross (2015) investigates how parental investments responded to better information about children's academic performance using a field experiment in Malawi that targeted parents with young children. Results show that providing parents with information about how each child is doing causes them to reallocate their educational investments across children so that investments correspond more closely to their children's true achievement level.

\footnotetext{
${ }^{13}$ Fryer, Levitt, and List (2015) focus on a different but related question, which is whether we can incentivize parents to invest more in their young children? They organized a randomized trial in Chicago in which parents were rewarded for activities such as attending educational sessions about early childhood, completing homework assignments with their children, and for their child's demonstration of mastery on interim assessments. These tasks were chosen to improve cognition and executive function. They found that the intervention benefited white and Hispanic children, but not African-American children. Moreover, effects were bigger for children with better cognitive skills to begin with. This study may illustrate some of the limits of trying to improve children's outcomes by working to improve parenting skills.
} 
Similarly, Cunha, Elo, and Culhane (2015) argue that U.S. mothers have poor information on the return to early childhood investments. They speculate that if the government could implement a policy that moved expectations from the median current belief to the true median return, that parental investments would go up by $4 \%$ to $24 \%$ and the stocks of cognitive skills at age 24 months would increase by $1 \%$ to $5 \%$. If parents lack information about the likely impact of investments in their children, then once again their behavior cannot be said to reflect their underlying preferences; perhaps information could be modeled as an input into child health production such that parents with incorrect information end up optimizing with respect to the wrong production function.

Perhaps an overall take away is that economists have been too quick to interpret parent's choices as revealed preference when even a simple economic model suggests that factors such as available production technologies and budgets, not to mention information, are likely to be tremendously important.

\section{Section 4: Sometimes Lightning Strikes Twice}

In this Section (and in Table 3) we consider a handful of studies that attempt to examine dynamic complementarities empirically using cases where there were two shocks. These studies are often reminiscent of the first generation of fetal origin studies in their reliance on quirky and exotic instruments (which is why we characterize them as akin to being struck twice by lightening), and in the fact that it may be difficult to generalize some of their conclusions to other settings. Nevertheless, they represent the frontier in terms of trying to apply insights from the theory outlined in Section 1 to applied work in this area. 
Aguilar and Vicarelli (2015) overlay variation from Mexico's conditional cash-transfer Progresa program on top of rainfall shocks induced by El Niño. They consider shocks that affected children both prenatally and up to age 2 and examine anthropometric and cognitive outcomes at ages 2 to 6 . They did not find that Progresa mitigated any of the negative effects of weather shocks. In contrast, Adhvaryu et al. (2015) use a very similar design and ask whether Progresa mitigated the effects of rainfall shocks on cognitive test scores and years of education measured at ages 12 to 21 . They estimate that Progresa offset 60 to $80 \%$ of the negative effects of rainfall shocks on child development. It is unclear whether these conflicting results are caused by subtle differences in the approaches taken, or whether it is really the case that one can see positive long-term effects even in cases where the immediate short-term effects appear to be negligible. Certainly much of the literature on early intervention programs has this flavor, finding initial effects that "fade out" by age 8 or 9 but then reappear in adulthood (Almond and Currie, 2011b).

Gunnsteinsson et al. (2016) examine data from a randomized controlled trial of Vitamin A supplementation in Bangladesh that took place between 2001 and 2007. In 2005, parts of the study area were devastated by a tornado. The authors find that tornado exposure in early pregnancy and early infancy had significant negative effects on birth weight and infant anthropometrics. However, they also find that infants treated with vitamin A at birth were effectively protected from the effects of experiencing a tornado shock at 0 to 3 months of age in that there did not appear to be any effect of the tornado on anthropometrics at 6 months. An unusual feature of this paper is the author's care in trying to entangle the optimal timing of the protective investment relative to the timing of the shock. 
One difference between Gunnesteinson et al. and Advharyu et al., is the amount of time that occurs between the negative shock and the human capital investment. While in the case of the tornado in Bangladesh the interval between the shock and the vitamin A supplementation was only a few months, and the outcome was measured a few months after that, in the Progresa paper, the interval between the transfer and the weather shock was at least a decade. The temporal gap between the first and the second event may be relevant to identifying these interactions, as there may be behavioral responses from parents or teachers that could either reinforce or undo the impacts of the first or the second event, or both.

Rossin-Slater and Wust (2015) consider a somewhat different, but related and very important question of how different types of common public early interventions interact. They use Danish registry data to study the interaction of a nurse home visiting program that supplies visits shortly after birth, and a childcare program for three-year-old children. Both programs rolled out beginning in the 1930s and ending in the 1950s. They find that the childcare program had large and persistent effects on educational attainment and income, and reduced adult mortality. In an innovative twist, they also find that the benefits extended inter-generationally to the children of the originally treated children.

A surprising finding however given the dynamic complementarities hypothesis, is that the effects of child care programs were largest for children who had not had exposure to the nurse home visiting program as newborns. At first blush this finding seems the opposite of the "skills beget skills" concept that children who got off to a good start due to the home visitors would be better able to benefit from the child care program. A possible explanation is that the programs actually provide similar but complementary services. For instance, home visiting often focuses 
on training parents about health and safety, as well as teaching them what they can expect developmentally from children of various ages. To the extent that a successful program trained parents to give better care at home, that might lesson the benefit of having better care in another setting. We are not aware of other studies of this type, so it is impossible to know how much the complementarities depend on the type of intervention, though it is reasonable to suppose that they would. Regardless, this handful of early two-shock studies establishes that estimating dynamic complementarities in a well-identified way is feasible with enough creativity and luck.

\section{Section 5: How Do Resources Mediate the Effect of Early Life Events?}

Broadly considered, there are two types of resources that can be expected to benefit children: Material resources $(Y)$ and time inputs $\left(I_{t}\right)$, which might be an argument in the production of child investments. In addition, parents of higher "quality" may be expected to make better use, on average, of the resources at their disposal (indeed, perhaps this should be considered as part of a definition of parent quality along with evidence of altruistic preferences towards the child). In equation (1), the productivity parameter $A$ might be indexed by parental type, with $A^{H}>A^{L}$, where H represents "high" quality and L represents "low" quality. At the same levels of income, type " $\mathrm{H}$ " parents could achieve better child outcomes (and higher consumption) than type "L" parents. As we discussed above, one might think of higher quality parents as having access to a different production function than other parents. Accordingly, in this section we focus on policies that affect parental education as well as income and in-kind support and parental leave policy.

a) Effects of Material Resources 
Many recent papers examine the effects of cash transfers on child outcomes in a range of settings. We can think of these policies as exogenously increasing $Y$, which according to (3), would increase both childhood investments and consumption. Aizer et al. (2016) assemble unique historical administrative data about the U.S. mother's Pension Program (a precursor to modern welfare programs). They ask whether being accepted into the program affected outcomes observable on WWII enlistment records or mortality risk (measured using age of death on death certificates). They find that being accepted increased longevity by 1.5 years on average, with larger effects in the poorest families.

Two papers, by Hoynes, Miller, and Simon (2015) and Dahl and Lochner (2012) examine the effect of the U.S. Earned Income Tax Credit Program (EITC). Although it is administered through the tax system, these refundable tax credits function rather like a Conditional Cash Transfer program in that they are mainly available to families who work and file a tax return, that is, they are conditional on working. Both papers exploit variation stemming from a significant increase in the generosity of the program in the mid-90s. The first study finds reductions in the incidence of low birth weight among mothers who benefited from the expansion while pregnant, while the second finds increases in a range of cognitive test scores, which are larger for children from the most disadvantaged families. One possible mechanism contributing to these effects is the positive link between EITC and mother's health (Evans and Garthwaite, 2014).

Black et al. (2014) and Milligan and Stabile (2011) consider cash transfers that are targeted to children (a child care subsidy and a child allowance, respectively). Like Dahl and Lochner, both also find significant improvements in a range of cognitive test scores. Milligan and Stabile find that these effects are mainly driven by boys. 
Set against these generally positive findings is the paper by Del Boca, Flinn, and Wiswall (2014) which estimates a structural model based on observational data from a variety of data sets. Their estimates suggest that monetary transfers will likely have only small effects on children because most of the transfer is likely to be spent on other types of consumption, or on parental leisure. However, they are not measuring the effects of an actual transfer policy using design-based variation in that policy.

A second group of papers looks "near cash" programs supplying food aid. It is often argued that if the amount of an in-kind transfer is small relative to the household's budget for that item, then in-kind transfers will have much the same impact as cash. The studies of the U.S. Food Stamp program (now known as SNAP, the Supplemental Nutrition Assistance Program) by Almond, Hoynes, and Schazenbach (2011) and Hoynes, Schazenbach, and Almond (2016) find (respectively) that the roll out of the program increased birth weights, especially among African Americans, and that in the long-term the roll out reduced the incidence of metabolic syndrome (i.e., obesity, high blood pressure, diabetes, etc.) which in turn increased the economic selfsufficiency.

Rossin-Slater (2013) examines the opposite type of policy, which is closures of clinics providing WIC (Supplemental Nutrition for Women, Infants, and Children) in Texas in the late 2000s. WIC closures reduced WIC participation, reduced the probability that a mother gained an adequate amount of weight during pregnancy, and reduced birth weight. Similarly, Meckel (2015) finds that crackdowns on WIC fraud caused small retailers to exit the program and reduced mother's prenatal participation in WIC with negative effects on birth outcomes. 
A number of studies look at the broader effects of economic circumstances on child outcomes. Arguably, good economic times may have effects not only through increasing family resources but also through increasing employment (with either positive or negative effects for children depending on the range of child care options available) and social resources. For example, more money may flow to schools and social services in good times. Hence, studies of the effects of business cycles may not tell us about precise mechanisms, though they do once again suggest the vulnerability of young children. The studies by Loken, Mogstad, and Wiswall (2012) and Adhvaryu et al. (2016) examine the oil boom in Norway and a cocoa price boom in Ghana, respectively. These find positive effects of good times with the impacts being felt disproportionately in low-income households.

Lindo (2011) and Carlson (2015) examine the effects of job displacement during pregnancy on health at birth outcomes. Lindo focuses on the father's job loss using data from the Panel Study of Income Dynamics and controlling for mother fixed-effects. Carlson uses data from notices filed under the Worker Adjustment and Retraining Notification Act aggregated at the county-month data to examine the effect of anticipated job losses. Both studies find negative effects on birth weight. Golberstein et al. (2016) go beyond examining effects on health at birth and examine children's mental health. The paper finds that a one standard deviation increase in the state unemployment rate has a negative impact on child's mental health (assessed using the Child Strength and Difficulties Questionnaire) and is associated with a 5.7\% increase in the use of special education services for emotional problems. Given the nature of the shock examined (i.e., the Great Recession) and the magnitude of the effects on clinically meaningful outcomes, it would be interesting to know whether these impacts will persist over time. 
Bharadwaj, Lundborg, and Rooth (2014) ask how low birth weight affects vulnerability to economic shocks later in life using Swedish administrative data and models with twin fixed effects. Their estimates suggest that a $10 \%$ increase in birth weight results in a one percent decline in the probability of using unemployment insurance during a recession as an adult. Conversely, using Dutch data, Scholte et al. (2015) find that individuals subjected to economic downturns early in life are more likely to have chronic diseases and functional limitations in old age.

Two studies by Gould, Lavy, and Paserman (2011) and Lavy, Schlosser, and Shany (2016) study the children of Ethiopian Jews who were air-lifted to Israel either as young children, or while in utero. Those children air-lifted to Israel experienced large differences in material conditions depending on where their families were assigned, and families had little say in this decision. Children who had running water, sanitation, and electricity in early childhood obtained more education, were more likely to be employed, and were less likely to have health problems in later life. Children air-lifted while in utero, faced different conditions during their mother's pregnancy compared to children air-lifted shortly after birth. Those children who experienced Israel's better conditions prior to 8 weeks of gestation did better on standardized tests and obtained more education. Perhaps curiously, these studies both find that the effects were concentrated mainly among girls. They attribute this finding to gender discrimination, particularly in Ethiopia and in the more backward parts of Israel. The idea is that parents would have been more likely to stint girls, so girls are particularly benefitted by relaxation of resource constraints. If this explanation is correct, then the result highlights the fact that the effects of a shock reflect both "biological" effects and the influence of social conditions, and that it is difficult to disentangle the two. 
Rossin-Slater (2016) highlights a very different type of policy which also had the capacity to change many aspects of a child's living situation: Changes in U.S. laws governing paternity establishment. Many states adopted policies aimed at making it easier to establish paternity in the hospital. A goal of these changes was to encourage parents to marry. Since married families are generally better off than single-parent households, such a policy might be expected to increase the resources available to children (both in terms of income and possibly father's time). However, Rossin-Slater argues that any positive effect on marriage rates was offset by the fact that the law also made it easier for some mothers to gain child-support without marrying the father. Overall, she finds little effect on measures of paternal involvement or child health, but some negative effect on children's health insurance coverage and utilization of medical care, which may be a result of losing access to paternal employer-sponsored health insurance coverage. This is one of very few studies to explicitly consider the role of fathers in providing resources to households, something that it would be useful to see more of.

Chetty, Hendren, and Katz (2016) focus on the Moving-to-Opportunity (MTO) experiment that randomly offered families living in housing projects vouchers that enabled them to move. Combining MTO experimental data with administrative data from federal tax returns, the authors find significant differences in the later-life outcomes of children who moved when they were less than 13 years old. Moving to a lower-poverty neighborhood improved college attendance rates by $15 \%$ and earnings by $14 \%$. Treated children were also $4 \%$ more likely to live in better neighborhoods as adults and $15 \%$ less likely to become single parents. In contrast, children who moved later in their adolescence either did not benefit or actually faced negative long-term impacts. One potential explanation for these differential effects is that moving to a very different environment as an adolescent could disrupt social networks and have other adverse 
effects on child development. The authors discuss potential intergenerational gains to providing access to better neighborhoods to families in public housing, which ultimately could generate positive of these policies returns for taxpayers.

\section{b) Policies to Promote Maternity Leave}

If childhood investments are an increasing function of parental time, then maternity leave policies may increase investments at key developmental stages. Such policies appear to be predicated on the belief that the elasticity of child investments in (1) with respect to parental time is large in very early childhood. The key policy question is when specifically maternal (or paternal) time is most important? Recent studies focusing on the effects of maternity leave policy on child outcomes are summarized in Panel B of Table 4. At first glance it is difficult to see any consistent picture in these estimates. However, on closer examination, a story emerges in which facilitating short maternity leaves is highly beneficial, but extended maternity leaves do not have a positive effect. This pattern seems plausible if child investments are an increasing but concave function of maternal time or if the return to childhood investments is diminishing in the investment level.

Rossin-Slater (2011) studies the implementation of the Family and Medical Leave Act in the U.S., a federal law allowing women to take up to 12 weeks of unpaid maternity leave. The law superseded a patchwork of state laws, creating a good deal of variation which she exploits. She finds a positive effect on the birth outcomes of college educated women. These women are more likely than less educated women to have been able to afford to take unpaid leave. Similarly, Carneiro, Loken, and Salvanes (2015) study the effect of a 1977 Norwegian law which replaced a legal right to 12 weeks of unpaid leave with four months of paid leave and an additional right 
to take 12 months of unpaid leave. They find that children of affected mothers got more education and had higher wages at age 30 . Thus it appears that allowing some maternity leave in the first months of life was associated with better outcomes in these two examples.

In contrast, Baker and Milligan (2015), Danzer and Lavy (2016), and Dahl et al. (2016) study expansions of paid leave from 25 weeks to 50 weeks, 12 months to 24 months, and 18 weeks to 35 weeks, respectively. Baker and Milligan (2015) actually find some evidence of negative effects on children's test scores among boys and among children of more educated mothers. Dahl et al. (2016) find no effects on adult outcomes. Danzer and Lavy (2016) do not find any overall effect, but report that there was some benefit to the reform for children of more highly educated mothers, but negative effects among children of less educated mothers. Thus, although there is some disagreement about the magnitude and direction of effects, there is little evidence in any of these studies that long maternal leaves have overall benefits for children. One possible interpretation is that mothers who go back to work after the first six months manage, on average, to find child care that approximates the care they would offer in their own homes.

\section{c) Policies to Promote Child Care}

Panel C of Table 4 reviews recent work on the feasibility of investing in young children through organized child care. These studies are organized into three categories: Long-term follow-ups of small-scale demonstration programs; long-term follow-ups of large, publicly funded programs; and short-term results of more recent demonstration programs.

There is a good deal of previous work showing long-term effects of small-scale child care demonstration programs conducted using randomized controlled trials including Perry Preschool and the Carolina Abcedarian Program. We have reviewed these programs extensively 
elsewhere. ${ }^{14}$ Suffice it to say here, these studies involved interventions of medium and strong intensity (respectively) with groups of very disadvantaged preschool children. At the time these demonstrations took place the alternative was generally no preschool, rather than some other type of preschool, which is the default today.

Studies by Heckman, Pinto and Savelyev (2013), Campbell et al. (2014), and Conti, Heckman, and Pinto (2015) add to this literature by showing that the interventions had positive effects on a broader set of outcomes than had previously been considered. In particular, they find positive effects on personality traits, health behaviors, and health outcomes. All of these measures have been shown to have important impacts on employment and earnings, though the focus in evaluations of early childhood interventions is often solely on test scores. These studies also take care to correct their estimates for complexities such as attrition and imperfect random assignment, as well as for multiple hypothesis testing (i.e., the problem that if you test 20 hypotheses, it is likely that one of them will fail to be rejected with $95 \%$ confidence even if there are in fact no underlying causal relationships). It is increasingly well understood that it can be difficult to interpret results from some randomized experiments given these sorts of problems.

A second set of studies extend the large literature on the effects of public preschool programs in various ways. Havnes and Mogstad (2015) examine the effect of a Norwegian reform that extended publicly funded preschools. The availability of preschool varied across space and time, and the authors exploit this variation to identify its effects. A striking finding is that the reform increased the eventual adult earnings of affected children in the poorest households, but reduced the earnings of affected children in the richest households. The paper is

\footnotetext{
${ }^{14}$ For instance, Almond and Currie (2011b) review some of the studies evaluating these programs in Table 11, p. 1435 .
} 
therefore a very nice demonstration of the fact that childcare centers do not exist in a vacuumhours in child care replace some other form of care for the child. If the care that is replaced is worse than the child care center, then one can expect improvements in child outcomes and vice versa. Of course income matters too. To the extent that child care allows women to work and earn more, their higher earnings may also benefit their children and could possibly offset a mild negative direct effect of child care. One would expect the marginal value of additional earnings to be higher in lower income households, even though more educated women are likely to earn more per hour.

A recent study by Baker, Gruber, and Milligan (2015) showed that the introduction of a universal child care program in Quebec led to negative effects on children's non-cognitive outcomes (with little gain in cognitive test scores), significant declines in long term self-reported health and life-satisfaction, and behavioral problems and criminal activity among boys. These results are quite consistent with those of Havnes and Mogstad because the modal child who was brought into child care as a result of the reform was a middle class child who went into a lowquality, hurriedly-created, child care facility.

Aizer and Cunha (2014), Gelber and Isen (2013), and Kline and Walters (2016) examine the U.S. Head Start program, a publicly funded program that originally served 3 to 5 year old children, but has increasingly served younger children as well. Aizer and Cunha (2014) focus on the roll out of Head Start in the mid-1960s using data from the National Collaborative Perinatal Project and find that children who were able to participate in Head Start had test scores that were 0.1 to 0.2 standard deviations higher at age 7 than those of their older siblings. However, like the parenting intervention studied by Fryer, Levitt, and List (2015), the effect was greatest for the 
children with the highest initial endowments. Aizer and Cunha also examine the compensation vs. reinforcement question, and find that in this low-resource setting, parents invested more in highly-endowed children and that parental investments complemented investments from Head Start. Gelber and Isen (2013) focus on parenting practices in Head Start cohorts from the early 2000s who were followed as part of the Head Start Impact Study, a randomized controlled trial intended to examine the short-run impacts of Head Start. They also find that Head Start enrollment tended to increase parental investments.

Kline and Walters (2016) offer a re-examination of data from the Head Start Impact Study. Original analyses found that Head Start had some positive effects on children in the short run, but that these effects quickly "faded out." Kline and Walters point out that about a third of the children treated in the Head Start Impact Study were drawn from other publicly-funded preschool programs and that many of the controls attended other public preschools. One would not necessarily expect to see any difference between Head Start children and children in other similar public preschool programs. Ignoring this fact substantially overstates the cost of providing Head Start to the study children (since a third of them would have been receiving preschool at public expense anyway), and also understates the positive effects of attending a public preschool of some sort; Hence naive estimates substantially understate the costeffectiveness of the program. Using estimates from previous work showing that short-term boosts in test scores are associated with long-term gains in outcomes (e.g., Garces et al, 2002; Chetty et al, 2011), they estimate that Head Start is likely to be a cost effective program. Interestingly, the eligible children who were not participating in the early 2000 s were those with the highest potential benefits, suggesting that expansions that drew these children into care could be even more cost effective. 
A common theme in these studies of public preschool programs in developed country settings is that a failure to consider the available alternatives to child care programs leads analysts to understate the positive social returns to expanding these programs.

A third group of recent studies (all randomized controlled trials) examine preschool programs in developing countries. The two papers by Attanasio and collaborators examine the effects of a home based psychosocial intervention program and a center-based preschool program that was implemented in poor Colombian towns. Both interventions find positive effects, though on different domains (cognitive test scores and height-for-age, respectively). Perhaps the main take away is that such publicly funded, large-scale programs can have positive effects even in very low resource settings. Gertler, Heckman, and Pinto et al. (2014) examine the long-term effects of an intervention to provide psychosocial stimulation to impoverished Jamaican children. An ambitious aspect of this project is that they attempted to track migrants, pointing out that in Jamaica, many successful people emigrate and are lost to follow up unless special care is taken to retain them in the study. This study finds large effects of the psychosocial intervention on adult earnings.

Taken as a whole, the studies summarized in Panel $\mathrm{C}$ of Table 4 add to the extensive literature on the potential for early intervention programs to improve children's short and longrun outcomes. Both high quality center-based programs and home visiting interventions appear to be effective and have the potential to influence many domains, including education, income, employment, health, and future health behaviors (see Almond and Currie, 2011b for a review of work on this topic before 2011).

\section{d) Policies to Promote Medical Care}


Much of the literature on the long-term effects of medical care in childhood exploits the revolutionary expansions of public health insurance (Medicaid) coverage to children in poor and near poor families that occurred in the U.S. during the 1980s and 1990s. But other rich countries have also made efforts to improve medical care for young children, and some of these investments have also been evaluated. Recent studies of the issue are reviewed in Panel D of Table 4.

One noteworthy study by Sievertsen and Wust (2015) uses rich administrative registry data from Denmark and exploits county-by-county variation policies mandating same-day postbirth discharge. Same-day discharge following normal deliveries was apparently implemented as a cost saving measure in a staggered way across Danish counties. They find that same-day discharge leads to a $75 \%$ increase in readmissions during the first month of life and also increases contacts with general practitioners. The largest effects are found for disadvantaged mothers (defined in terms of age, education, and income). The authors are able to link administrative data sets together in order to examine long-term effects of this policy change on 9th grade test scores. They find that the policy was associated with a .2 standard deviation decline in test scores in children born to disadvantaged mothers. While modest, this effect is in line with the effect sizes seen in many educational interventions and highlights the interrelationship of health and cognitive achievement.

Bharadwaj, Loken, and Neilson (2013) examine infants in Chile and Norway and exploit the fact that infants below the $1500 \mathrm{~g}$ threshold cutoff used to define very low birth weight received more intensive medical services than those just above this threshold. In addition to 
finding significant effects on infant mortality in each country, they also find that more intensive medical care increased adult wages by $2.7 \%$ in Chile and by $1.8 \%$ in Norway.

Studies of the U.S. Medicaid expansions use a variety of methodologies and data sets, but generally rely on the fact that the Medicaid expansions were phased in at different rates across the states (although the expansions eventually became mandatory in every state). Brown, Kowalski, and Lurie (2015) use U.S. Internal Revenue data from tax returns which allows them to examine income and payroll taxes as well as college attendance as outcomes. Cohodes et al. (2016) use publicly available data from the Census, the Current Population Survey, and the Youth Risk Behavior Surveillance System to examine effects on educational attainment. Meyer and Wherry (2016) and Miller and Wherry (2014) examine effects on mortality using Vital Statistics data and on obesity, body mass index, and hospitalizations for endocrine disorders using data from the NHIS, while Wherry et al. (2015) look at hospitalizations and Emergency Room visits using hospital discharge data.

All of these studies find positive long-term effects of having been eligible for health insurance coverage in childhood, suggesting that improved access to medical care in childhood increases the health and productivity of adults. These findings are significant as Medicaid is possibly the largest U.S. policy engaging "fetal origins" linkages, and represents one of the largest social investments that has been made in U.S. children. There is some heterogeneity in the estimated long-term effects. The effects are strongest for African Americans (who were most strongly affected by the expansions, given their lower average incomes and resulting higher eligibility for public insurance). Brown et al. do not see race in the tax data, but find stronger effects on earnings among women than among men. The take away from these studies is that 
even in rich countries where much of the morbidity is due to behavioral factors rather than infectious disease, improvements in access to medical care matter for long-term outcomes, especially among the disadvantaged.

\section{e) Maternal Education}

In Grossman (1972), more educated individuals are more efficient producers of health. Analogously here, it may be the case that better educated parents have $\mathrm{A}=A^{H}>A^{L}$, which would yield higher child outcomes $h$, other things equal. As Currie and Moretti (2003) point out, maternal education is endogenously chosen, and has possible effects on many aspects of a woman's life, ${ }^{15}$ including fertility choices. McCrary and Royer (2011) and Carneiro, Meghir, and Parey (2012) examine the effect of policies that affected the amount of maternal education. The first paper exploits discontinuities created by rules about age-at-school entry. The idea is that children who are slightly too young to enter school must wait a year and will be in lower grades when they reach the age at which they can legally leave school causing the marginal children to end up with less education than children who were just above the age cutoff for school entry. McCrary and Royer find little overall effect of additional compulsory education on either fertility or infant health, though for African-American women, they do find some reduction in the incidence of low birth weight.

This result contrasts with Currie and Moretti, who examined the effect of additional years of college education induced by having a college open in the mother's county when she was 17 years old. These openings were associated with large improvements in infant health, possibly

\footnotetext{
${ }^{15}$ There is no time budget in our stylized model. Were labor income a function of hours worked, then another margin for optimization would presumably be through the shadow price of parental time spent on investing in children. Increases in education could increase the return to work and shadow price of time spent investing in children, with ambiguous predictions on net investments given competing income and substitution effects.
} 
through the mechanism of reducing maternal smoking. McCrary and Royer study a different margin (years of high school) and find no effect on smoking, so a possible explanation for these conflicting results is that the studies are looking at different margins presumably affecting different parts of the distribution of potential mothers. Carneiro et al. (2012) also focus on college education and instrument for education using variables such as tuition and distance to college. They find positive effects on child test scores, with slightly larger effects for African Americans.

In order to place these results in context, it is important to note that the fraction of U.S. women with less than a high school degree has fallen by more than $50 \%$ in the last 25 years, and there is increasing evidence that high school dropouts and those with only a high school degree fare similarly in the labor market (Card, 2009). Hence, college may be the key margin for maternal education to affect child health in the United States.

\section{Section 6: The Missing Middle and Latent Effects}

In order to examine the long-term impact of policies experienced as young children, researchers must wait patiently to observe a "fully formed" measure of $h$. For example, Hoynes et al. (2016), Dahl et al. (2016), and Isen, Rossin-Slater, and Walker (2016) study the impact of policies that were rolled out 30 to 40 years ago. In addition to the usual difficulties identifying policy effects, these studies must address the problems involved in tracking affected people or cohorts over decades. In the case of Hoynes et al. (2016) the problem was addressed by gaining restricted-access information on county of residence over time in the Panel Study of Income Dynamics, while the other two studies rely on administrative records that geocode county of birth. 
Clearly, while long-term follow up is the most reliable way to assess whether a policy is effective in the long-term, it limits our ability to assess current or even recent policies within a reasonable amount of time. While economists may be particularly interested in adult productivity and earnings, skipping the middle years between early childhood and adulthood means that we have little idea about what typical developmental trajectories look like and how they are shaped by policies experienced over the life course. If we knew more about the relationship between early childhood, middle-childhood, and adulthood, it would aid us in making medium-term inferences about those early childhood policies that are likely to successfully impact adults. Our lack of knowledge also means that we are largely shooting in the dark when trying to compare the efficacy of programs targeted at very young children to those targeting older children. While there is a wide-spread perception that it is more cost-effective to focus on the very young, there is surprisingly little direct comparison of policies targeting different age groups.

An additional reason to be interested in the middle years, is that the limited amount that we do know presents some real puzzles. For instance, a common finding in the literature evaluating early childhood intervention programs is that there is an immediate gain in test scores, followed by "fade out" of test score gains in the early elementary school years (Almond and Currie, 2011b; Currie and Thomas, 1995). However, these same children tracked many years later often show positive effects of the intervention in terms of completed schooling attainment and other measures (Garces et al, 2002). Are the initial test score effects a "red herring" in that the intervention is really affecting something else that matters for future development (such as non-cognitive skills)? Or do the initial effects on cognition simply become latent for some period of time and re-emerge? 
In many cases, data on the "missing middle" is simply unavailable. For instance, Isen, Rossin-Slater, and Walker know where people were born, and link information about their birth counties to their adult earnings records. Their data has no information on movement patterns between birth and adulthood, which is perhaps something that could be examined using tax records, as in Chetty et al. (2016). However, a few recent papers have begun to examine the effects of events in early childhood on outcomes during the school years.

A few of these papers have already been discussed. For example, in student register data for Pakistani and Bangladeshi families in England, Almond et al. (2015) examined whether Ramadan's overlap with pregnancy affects subsequent academic outcomes at age 7. They find that test scores are 0.05 to 0.08 standard deviations lower for students exposed to Ramadan in early pregnancy.

A few additional studies focusing on middle childhood are summarized in Table 5. Figlio et al. (2014) use the universe of births in Florida matched to data from standardized tests. They find that in models with twin fixed effects, increases in birth weight are associated with higher performance. The estimates are slightly smaller than those found in Black, Devereux, and Salvanes (2007) who conducted a similar investigation in Norway. Bharadwaj, Eberhard, and Neilson (2013) report very similar findings for Chile. A further interesting result is that the effects of low birth weight are largely stable between the ages of 9 and 14 in Florida, and between 1st and 12th grade in Chile.

Another approach to the problem of measuring trajectories is to try to develop better measures of fetal damage, i.e., quantifying $\mu_{1 g}$ and $\mu_{2 g}$. We know for example, that low birth weight is an extremely crude measure of fetal damage, which while predictive, is certainly not 
dispositive. There are babies who were low birth weight who seem to be just fine ex-post, and many babies who are not low birth weight but who nonetheless have developmental problems. Robinson (2012) attempts to distinguish between "brain sparing" forms of low birth weight, and low birth weight that is associated with evidence of brain damage. He does this largely by focusing on head circumference, which may feel uncomfortably close to the preoccupations of early eugenicists. His estimates suggest that there are no cognitive effects of low birth weight in the infants with brain sparing. However, his low birth weight infants were more likely than normal weight siblings to have congenital malformations, and vision, hearing, or speech abnormalities regardless of head circumference. Biomedicine has proposed some intriguing alternative metrics to birth weight, e.g., telomere length, methylation patterns, etc., but none that have gained widespread acceptance as yet.

The multidimensional nature of both investments $(I)$ and outcomes (h) (Heckman, 2007) is one reason for the measurement problem. It is unclear whether any unidimensional metric will ever fully capture the effects of early childhood policies and investments insofar as they will impact later life outcomes. At present, waiting until cohorts reach adulthood to observe effects remains useful, though it is severely limiting. For example, how do we know today whether policy A or B will have bigger long-term effects? Presumably this is where a structural, wellcalibrated model of investments in early childhood and human capital formation could help to fill the gaps in our knowledge. In addition, a potential avenue of research could be the development 
of "sufficient statistics" to identify key reduced-form elasticities that summarize the human capital effects of early life shocks or investments. ${ }^{16,17}$

\section{Section 7: Discussion and Conclusions}

We now know that variegated shocks, some of them relatively mild and brief, can have lasting measurable impacts on child outcomes. Many authors start from the basic, scientific perspective of asking whether shock $X$ has a casual effect on outcome $Y$. While that is an important question, it is reasonable to ask whether, given all of this research, we can say anything yet about the relative magnitudes of the effects and in particular, about which investments and interventions would be most cost effective in terms of improving young children's future outcomes? Answering this question is hampered by the wide range of both shocks and outcomes that have been considered. However, at this point a large number of studies have examined three types of outcomes: Birth weight (and low birth weight), test scores, and wages -- three outcomes that offer glimpses of an individual's well-being at birth, in childhood, and in adulthood.

Table 6 summarizes what some of these studies have found. These estimates do not lend themselves to comparative analysis of cost-effectiveness. For one thing, we do not have estimates of what it would cost to prevent or ameliorate some types of shocks such as stress due to a death in the family or domestic violence. Still, given what we know about interventions that

\footnotetext{
${ }^{16}$ Bleakley (2010), for instance, showed that years of schooling is not a sufficient statistic for measuring the impact of early-life health on lifetime income as it is possible that when health improves, lifetime income goes up, but years of schooling declines.

${ }^{17}$ The use of sufficient statistics has been relatively common in other fields of economics such as in public finance, for welfare analysis. For instance, Chetty (2009) showed that in order to calculate the welfare impact of a tax policy, one only needs to estimate the elasticity of equilibrium quantity with respect to the tax rate and avoid estimating all the "primitive" parameters in a structural model.
} 
are feasible and a rough idea about the likely costs of intervention, the table can serve as a starting point for a discussion about what interventions appear to be most promising.

Studies that focus on birth weight as an outcome are shown in Panel A. Unfortunately, we don't know whether small changes in birth weight for babies well above the cutoff for low birth weight will have meaningful effects on future adult outcomes. Studies that focus on effects on mean birth weight can answer the rudimentary question of whether a given shock affects the fetus, but are not necessarily well suited to considering the cost effectiveness of intervention because we don't know how much a small change in the entire distribution of birth weight is likely to be worth.

On the other hand, we do know that low birth weight is associated in a meaningful way with future outcomes such as adult health, schooling attainment, and wages (see for example, Bharadwaj, Lundborg, and Rooth, 2014; Bharadwaj, Eberhard, and Neilson, 2013; Figlio, Guryan, Karbownik, and Roth, 2014). Table 6 suggests that there is low hanging fruit in terms of potential for meaningful interventions to reduce the incidence of low birth weight. For example, Schwandt (2016) finds that reducing severe influenza cases among pregnant women would have a meaningful effect on the incidence of low birth weight (and on children's future wages). This goal could be accomplished quite cheaply by promoting immunization for influenza among women of child bearing age.

Hoynes, Miller, and Simon (2015), Almond, Hoynes, and Schazenbach (2011), and Rossin-Slater (2013) find that small increases in annual income (or equivalent in-kind transfers) have relatively large impacts on the incidence of low birth weight, which suggests that some sort of pregnancy bonus or mother's allowance might have positive effects at a modest cost 
(compositional effects aside). Another policy which could accomplish the same thing though perhaps at higher cost is paid maternity leave, which would be particularly valuable if it covered some of the prenatal period (Rossin-Slater, 2011).

Conversely, uncertainty about income seems to be extremely harmful (Carlson, 2015). It isn't clear at this point how much this problem could be mitigated by expanding unemployment insurance, or at what cost. For example, we don't know how many pregnant women or their partners now qualify for unemployment insurance (UI) or how much they typically receive in benefits. Lindo (2011) finds extremely negative effects of paternal unemployment, though again, it is not clear what policy response could best prevent or address this. This result does point to the importance of fathers, a topic that has generally been neglected in the literature.

Currie and Walker (2011) and Currie et al. (2013) show that exposure to pollution during pregnancy has particularly negative effects on the developing fetus. The cost of pollution control varies greatly depending on exactly how it is done. One option that has not been explored a great deal to date is the potential role of zoning to keep residences, schools, and child care centers away from sources of pollution such as busy highways. Over time, zoning changes might accomplish a lot in terms of health protection at a relatively modest cost. Improvements in filtration by daycare and school HVAC systems are probably cheaper still.

The second panel of Table 6 briefly summarizes shocks that have been shown to affect future test scores. Perhaps unsurprisingly, the same things that have an impact on low birth weight often have significant impacts on test scores. Black et al. (2014), Milligan and Stabile (2011), Dahl and Lochner (2012) all show that small increases in annual income in childhood has measurable effects on children's test scores. Sanders (2012), Bharadwaj et al. (2016), and Black, 
Butikofer, Devereux, and Salvanes (2014) further explore the effects of pollution, while Aizer, Stroud, and Buka (2016) highlight negative effects of maternal stress during pregnancy on test scores.

Almond, Mazumder, and Van Ewikjk (2015) and Greve, Shultz-Nielsen, and Tekin (2015) focus particularly on mild nutritional deprivation during pregnancy and find large negative effects on test scores. It would be particularly interesting to tie this literature on mild nutritional deprivation together with the literature on nutritional supplementation (e.g., analyses of the U.S. WIC program) to draw inferences about the potential effects of small variations in nutrition during pregnancy.

Turning to shocks in early childhood that have been shown to impact the wages of young adults, panel $\mathrm{C}$ of Table 6 points once again to some of the same suspects. Policies to improve immunization for influenza (Schwandt, 2016), reduce alcohol consumption in pregnant women (Nilsson, 2015), and reduce exposure to pollution (Isen et al., 2015) hold considerable promise. Maternity leave in very early childhood (Carneiro et al., 2015), child care subsidies (Havnes and Mogstad, 2011), and health insurance coverage for young children (Brown et al., 2015) all appear to have payoffs down the road. The Gertler et al. (2014) study of psychosocial stimulation applies to very disadvantaged children in a developing country. Yet there may be parallels to nurse home visiting programs that target disadvantaged parents in the U.S. and many developed countries.

Clearly, we cannot pin down specific cost-benefit ratios without a lot more information. But arguably we have still learned quite a bit about the types of interventions that could be expected to make children healthier, smarter, and more productive as adults. 
That said, there remains a great deal of room for future research. More progress could be achieved if some of the measurement problems could be addressed. Some of our most widely used measures, such as low birth weight, are at best only proxies for a whole range of subtle damages that a developing fetus may have suffered. Without sensitive and specific "real time" measures of how someone has been harmed, and how interventions are affecting them, all we can do is wait and see what the eventual outcome will be. In addition to specific measures of harms, knowing more about how intermediate outcomes are affected could help us to identify individuals in need of assistance more quickly, and to target interventions more effectively.

Similarly, being able to identify sensitive or critical periods when particular shocks have their greatest impact, would be extremely helpful. To date, we have learned that the in utero period is itself an especially critical and sensitive period of an individual's life. But breaking this period down further and learning more about critical periods in early childhood would also be extremely useful. If the early stages of pregnancy matter most, does starting WIC a few weeks earlier have a high return? Does fostering earlier recognition of pregnancies help?

Another area that could benefit from more precise measurement concerns the development of non-cognitive skills. A few of the studies discussed above focus on noncognitive skills, and there is growing evidence that such "soft" skills matter a great deal in terms of producing "hard" outcomes such as educational attainment and employment. Yet these skills are typically represented by a hodge-podge of different measures that happen to be available to researchers and there is no consensus as yet on which measures are best or how to get a comprehensive overview of an individual's non-cognitive skills. 
We have emphasized that there is often considerable heterogeneity in the effects of a given shock. Most often, more disadvantaged people suffer greater harms, though not always. It is perfectly reasonable that there should be heterogeneous effects given differences in endowments, budget constraints, and available production technologies. Yet in many cases effective interventions may depend on knowing the source of the heterogeneity, something we can largely only speculate about now. Moreover, as we have discussed, families may act either to magnify or mitigate the effects of initial shocks. Hence, a greater understanding of the way that shocks and disadvantage interact, and of the role of parents in responding to them, is highly desirable.

To date, most of the literature focuses on the role of mothers, largely because we have had much better information about mothers than about fathers in many data sets. As large administrative data sets have become increasingly available, it has become possible to explore the role of fathers, but this exploration is only just beginning.

Similarly, improvements in the availability of data are making it possible to explore intergenerational effects. Given evidence from animal models, it is highly likely that changes in the fetus or young child could be passed on to the next generation. This type of mechanism could offer an additional reason for the intergenerational persistence of poverty, and for the existence of poverty traps in some disadvantaged areas.

\section{References}

Adhvaryu, A., Bednar, S., Molina, T., Nguyen, Q., and Nyshadham, A. (2016) When It Rains It Pours: The Long-run Economic Impacts of Salt Iodization in the United States. Working paper. 
Adhvaryu, A., Fenske, J., and Nyshadham, A. (2016) Early Life Circumstance and Adult Mental Health. Journal of Political Economy, R\&R.

Adhvaryu, A. and Nyshadham, A. (2016) Endowments at Birth and Parents' Investments in Children. The Economic Journal, 126(593): 781-820.

Adhvaryu, A., Molina, T., Nyshadham, A., and Tamayo, J. (2015) Helping Children Catch Up: Early Life Shocks and the Progresa Experiment. Working paper.

Agüero, J.M. (2014) Long-Term Effect of Climate Change on Health: Evidence from Heat Waves in Mexico. IDB Working Paper, 481.

Aguilar, A. and Vicarelli, M. (2015) El Nino and Mexican Children: Medium-term effects of early-life weather shocks on cognitive and health outcomes. Working paper.

Aizer, A. (2011) Poverty, Violence and Health: The Impact of Domestic Violence during Pregnancy on Newborn Health. Journal of Human Resources, 46(3): 518-538.

Aizer, A. and Cunha, F. (2014) Child Endowments, Parental Investments and the Production of Human Capital. Journal of Political Economy, R\&R.

Aizer, A. and Currie, J. (2014) The Intergenerational Transmission of Inequality: Maternal Disadvantage and Health at Birth. Science, 344 (Issue 6186): 856:861.

Aizer, A., Currie, J., Simon, P., and Vivier, P. (2016) Do Low Levels of Blood Lead Reduce Children's Future Test Scores? NBER Working paper, 22558.

Aizer, A., Eli, S., Ferrie, J., Lleras-Muney, A. (2016) The Long Term Effects of Means Tested Cash Transfers During Childhood. American Economic Review, 106(4): 935-971.

Aizer, A., Stroud, L., and Buka, S. (2016) Maternal Stress and Child Outcomes: Evidence from Siblings. Journal of Human Resources, 51(3): 523-555.

Akee, R., Simeonova, E., Costello, E.J., Copeland, W., and Angold, A. (2015) How Does Household Income Affect Child Personality Traits and Behaviors? NBER Working paper, 21562.

Almond, D. (2006) Is the 1918 Influenza Pandemic Over? Long-term Effects of In Utero Influenza Exposure in the post-1940 US Population. Journal of Political Economy, 114(4): 672712.

Almond, D. and Currie, J. (2011a) Killing Me Softly: The Fetal Origins Hypothesis. Journal of Economic Perspectives, 25(3): 153-172.

Almond, D. and Currie, J. (2011b) Human Capital before Age Five. In the Handbook of Labor Economics, edited by Ashenfelter, O. and Card, D. Vol. 4 (Chapter 15): 1315-1486. 
Almond, D., Currie, J., and Hermann, M. (2011) From Infant to Mother: Early Disease Environment and Future Maternal Health. Labour Economics, 19(4): 475-483.

Almond, D., Doyle, J., Kowalski, A., and Williams, H. (2010) Estimating Marginal Returns to Medical Care: Evidence from At-risk Newborns. The Quarterly Journal of Economics, 125 (2): 591-634.

Almond, D., Edlund, L., Joffe, M., and Palme, M. (2016) An Adaptive Significance of Morning Sickness? Trivers-Willard and Hyperemesis Gravidarum. Economics and Human Biology, 21: $167-171$.

Almond, D., Edlund, L., and Palme, M (2009) Chernobyl's Subclinical Legacy: Prenatal Exposure to Radioactive Fallout and School Outcomes in Sweden. The Quarterly Journal of Economics, 124 (4): 1729-1772.

Almond, D., Hoynes, H., and Whitmore Schanzenbach, D. (2011) Inside the War on Poverty: The Impact of Food Stamps on Birth Outcomes. Review of Economics and Statistics, XCIII (2): 387-402.

Almond, D. and Mazumder, B. (2011) Health Capital and the Prenatal Environment: The Effect of Ramadan Observance during Pregnancy. American Economic Journal: Applied Economics, 3(4): 56-85.

Almond, D., Mazumder, B., and Van Ewijk, R. (2015) Fasting During Pregnancy and Children's Academic Performance. The Economic Journal, 125(589): 1501-1533.

Angrist, J. and Pischke, J.S. (2010) The Credibility Revolution in Empirical Economics: How Better Research Design Is Taking the Con out of Econometrics. Journal of Economic Perspectives, 24(2): 3-30.

Anttila-Hughes, J.K. and Hsiang, S. (2013) Destruction, Disinvestment, and Death: Economic and Human Losses Following Environmental Disaster. GSPP Working paper.

Arceo-Gomez, E., Hanna, R., and Oliva, P. (2012) Does the Effect of Pollution on Infant Mortality Differ Between Developing and Developed Countries? Evidence from Mexico City. The Economic Journal, 126(591): 257-280.

Attanasio, O., Di Maro, V., and Vera-Hernandez, M. (2013) Community Nurseries and the Nutritional Status of Poor Children. Evidence from Colombia. The Economic Journal, 123(9): 1025-1058.

Attanasio, O., Fitzsimons, E., Grantham-McGregor, S., Meghir, C., and Rubio-Codina, M. (2014) Using the Infrastructure of a Conditional Cash Transfer Program to Deliver a Scalable Integrated Early Child Development Program in Colombia: A Cluster Randomized Controlled Trial. BMJ, 349: g5785. 
Baird, S., Hamory Hicks, J., Kremer, M., and Miguel, E. (2016) Worms at Work: Long-run Impacts of Child Health Gains. Forthcoming at the Quarterly Journal of Economics. doi: 10.1093/qje/qjw022.

Baker, M., Gruber, J., and Milligan, K. (2015) Non-Cognitive Deficits and Young Adult Outcomes: The Long-Run Impacts of a Universal Child Care Program. NBER Working paper, 21571.

Baker, M. and Milligan, K. (2016) Boy-Girl Differences in Parental Time Investments: Evidence from Three Countries. Forthcoming at the Journal of Human Capital.

Baker, M. and Milligan, K. (2015) Maternity Leave and Children's Cognitive and Behavioral Development. Journal of Population Economics, 28(2): 373-391.

Barham, T., Macours, K., and Maluccio, J. (2013) Boys' Cognitive Skill Formation and Physical Growth: Long-Term Experimental Evidence on Critical Ages for Early Childhood Interventions. American Economic Review: Papers \& Proceedings, 103(3): 467-471.

Barker, D.J.P. (1998) In Utero Programming of Chronic Disease. Clinical Science, 95(2): 11528.

Barreca, A. and Page, M. (2015) A Pint for a Pound? Minimum Drinking Age Laws and Birth Outcomes. Health Economics, 24(4): 400-418.

Beach, B., Ferrie, J., Saavedra, M., and Troesken, W. (2016) Typhoid Fever, Water Quality, and Human Capital Formation. The Journal of Economic History, 76(1): 41-75.

Bhalotra, S. and Venkataramani, A. (2015) Shadows of the Captain of the Men of Death: Early Life Health Interventions, Human Capital Investments, and Institutions. Journal of Political Economy, $R \& R$.

Bhalotra, S. and Venkataramani, A. (2013) Cognitive Development and Infectious Disease: Gender Differences in Investments and Outcomes. Working paper.

Bharadwaj, P., Lundborg, P., and Rooth, D. (2014) The Effects of Birth Weight over the Life Course. Working paper.

Bharadwaj, P., Eberhard, J., and Neilson, C. (2013) Health at Birth, Parental Investments, and Academic Outcomes. Journal of Human Resources, $R \& R$.

Bharadwaj, P., Gibson, M., Graff-Zivin, J., and Nielsen, C. (2016). Grey Matters: Fetal Pollution Exposure and Human Capital Formation. Forthcoming at the Journal of the Association of Environmental and Resource Economists. 
Bharadwaj, P., Johnsen, J.V., and Løken, K.V. (2014) Smoking Bans, Maternal Smoking, and Birth Outcomes. Journal of Public Economics, 115: 72-93.

Bharadwaj, P., Løken, K.V., and Neilson, C. (2013) Early Life Health Interventions and Academic Achievement. American Economic Review, 103(5): 1862-1891.

Bharadwaj, P. and Lakdawala, L (2013) Discrimination Begins in the Womb: Evidence of Sex Selective Prenatal Investments. Journal of Human Resources, 48(1): 71-113.

Billings, S. and Schnepel, K. (2015) Life Unleaded: Effects of Early Interventions for Children Exposed to Lead. American Economic Journal: Applied Economics, $R \& R$.

Black, S., Bütikofer, A., Devereux, P., and Salvanes, K. (2013) This Is Only a Test? Long-Run Impacts of Prenatal Exposure to Radioactive Downfall. NBER Working paper, 18987.

Black, S., Devereux, P., Løken, K.V., and Salvanes, K. (2014) Care or Cash? The Effect of Child Care Subsidies on Student Performance. Review of Economics and Statistics, 96(5): 824-837.

Black, S., Devereux, P., and Salvanes, K. (2007) From the Cradle to the Labor Market? The Effect of Birth Weight on Adult Outcomes. The Quarterly Journal of Economics, 122(1): 409439.

Blackhouse, R.E. and Medema, S.G. (2009) Retrospectives: On the Definition of Economics. Journal of Economic Perspectives, 23(1): 221-233.

Bleakley, H. (2007) Disease and Development: Evidence from Hookworm Eradication in the American South. The Quarterly Journal of Economics, 122(1): 73-117.

Bleakley H. (2010) Malaria Eradication in the Americas: A Retrospective Analysis of Childhood Exposure. American Economic Journal: Applied Economics, 2(2): 1-45.

Breining, N., Daysal, M., Simonsen, M., and Trandar, M. (2015) Spillover Effects of Early-Life Medical Interventions. IZA Working paper, 9086.

Brown, D.W., Kowalski, A.E., and Lurie, I.Z. (2015) Medicaid as an Investment in Children: What is the Long-term Impact on Tax Receipts? NBER Working paper, 20835.

Campbell, F., Conti, G., Heckman, J.J., Moon, S.H., Pinto, R., Pungello, E., and Pan, Y. (2014) Early Childhood Investments Substantially Boost Adult Health. Science, 343(6178): 1478-1485.

Card, D. (1999) The Causal Effect of Education on Earnings. In the Handbook of Labor Economics, edited by Ashenfelter, O. and Card, D. Vol. 3 (Chapter 30): 1801-1863.

Card, D. (2009) Immigration and Inequality. American Economic Review 99 May. 
Carlson, K. (2015) Fear Itself: The Effects of Distressing Economic News on Birth Outcomes. Journal of Health Economics, 41: 117-132.

Carneiro, P. and Ginja, R. (2014) Long Term Impacts of Compensatory Preschool on Health and Behavior: Evidence from Head Start. American Economic Journal: Economic Policy, 64(4): 135-173.

Carneiro, P., Løken, K.V., and Salvanes, K. (2015) A Flying Start? Long Term Consequences of Time Investments in Children during their First Year of Life. Journal of Political Economy, 123: $365-412$.

Carneiro, P., Meghir, C. and Parey, M. (2012) Maternal Education, Home Environments and the Development of Children and Adolescents. Journal of the European Economic Association, 11(s1): 123-160.

Chetty, R. (2009) Sufficient Statistics for Welfare Analysis: A Bridge between Structural and Reduced-Form Methods. Annual Review of Economics, 1: 451-87.

Chetty, R., Friedman, J., Hilger, N., Saez, E., Whitmore Schanzenbach, D., and Yagan, D. (2011) How Does Your Kindergarten Classroom Affect Your Earnings? Evidence from Project STAR. The Quarterly Journal of Economics, 126(4): 1593-1660.

Chetty, R., Hendren, N., and Katz, L. (2016) The Effects of Exposure to Better Neighborhoods on Children: New Evidence from the Moving to Opportunity Experiment. American Economic Review, 106(4): 855-902.

Cohodes, S., Grossman, D., Kleiner, S.A., and Lovenheim, M., (2014) The Effect of Child Health Insurance Access on Schooling: Evidence from Public Insurance Expansions. Journal of Human Resources, 51(3): 727-759.

Conti, G., Heckman, J., and Pinto, R. (2015) The Effects of Two Influential Early Childhood Interventions on Health and Healthy Behaviors. NBER Working paper, 21454 (forthcoming, Economic Journal).

Costa, D.L. (2000) Understanding the Twentieth-Century Decline in Chronic Conditions among Older Men. Demography, 37(1): 53-72.

Cunha, F., Elo, I., and Culhane, J. (2015) Eliciting Maternal Beliefs about the Technology of Skill Formation. American Economic Review, $R \& R$.

Cuhna, F. and Heckman, J.J. (2008) Formulating, Identifying and Estimating the Technology of Cognitive and Noncognitive Skill Formation. Journal of Human Resources, 43(4): 738-782.

Cuhna, F., Heckman, J.J., and Schennach, S.M. (2010) Estimating the Technology of Cognitive and Noncognitive Skill Formation. Econometrica, 78(3): 883-931. 
Currie J. (2009) Healthy, Wealthy, and Wise: Socioeconomic Status, Poor Health in Childhood, and Human Capital Development. Journal of Economic Literature, 47(1): 87-122.

Currie J. (2011) Inequality at Birth: Some Causes and Consequences. American Economic Review, 101(3): 1-22.

Currie, J., Graff -Zivin, J.S., Meckel, K., Neidell, M.J., and Schlenker, W. (2013) Something in the Water: Contaminated Drinking Water and Infant Health. Canadian Journal of Economics, Canadian Economics Association, 46(3):791-810.

Currie, J. and Hyson, R. (1999) Is the Impact of Shocks Cushioned by Socioeconomic Status? The Case of Low Birth Weight. American Economic Review, 89(2): 245-250.

Currie, J. and Moretti, E. (2003) Mother's Education and the Intergenerational Transmission of Human Capital: Evidence from College Openings. The Quarterly Journal of Economics, VCXVIII (4): 1495-1532.

Currie, J. and Rossin-Slater, M. (2013) Weathering the Storm: Hurricanes and Birth Outcomes. Journal of Health Economics, 32(3): 487-503.

Currie, J. and Schwandt, H. (2013) A Within-Mother Analysis of Seasonal Patterns in Health at Birth. Proceedings of the National Academy of Sciences, 110(30): 12265-12270.

Currie, J. and Thomas, D. (1995) Does Head Start make a Difference? American Economic Review, 85(3): 341-364.

Currie, J. and Walker, R. (2011) Traffic Congestion and Infant Health: Evidence from E-ZPass. American Economic Journal: Applied Economics, 3(1): 65-90.

Dahl, G. and Lochner, L. (2012) The Impact of Family Income on Child Achievement: Evidence from the Earned Income Tax Credit. American Economic Review, 102(5): 1927-1956.

Dahl, G., Løken, K.V., Mogstad, M., and Salvanes, K. (2016) What is the Case for Paid Maternity Leave? Review of Economics and Statistics, 98(4): 655-670.

Danzer, N., and Lavy, V. (2016) Paid Parental Leave and Children's Schooling Outcomes. Forthcoming at The Economic Journal.

Daysal, N.M., Trandafir, M., and van Ewijk, R. (2015) Saving Lives at Birth: The Impact of Home Births on Infant Outcomes. American Economic Journal: Applied Economics, 7(3): 2550 .

Del Boca, D., Flinn, C., and Wiswall, N. (2014) Household Choices and Child Development. Review of Economic Studies, 81(1): 137-185. 
Del Bono, E., Ermisch, J., and Francesconi, M. (2012) Intrafamily Resource Allocations: A Dynamic Model of Birth Weight. Journal of Labor Economics, 30(3): 657-706.

Dinardo, J. (2007) Interesting Questions in Freakonomics. Journal of Economic Literature, 45(4): 973-1000.

Dizon-Ross, R. (2015) Parents' Perceptions and Children's Education: Experimental Evidence from Malawi. Working paper.

Evans, W. and Garthwaite, C. (2014) Giving Mom a Break: The Effect of Higher EITC Payments on Maternal Health. American Economic Journal: Economic Policy, 6(2): 258-90.

Feyrer, J., Politi, D., and Weil, D.N. (2013) The Cognitive Effects of Micronutrient Deficiency: Evidence from Salt Iodization in the United States. NBER Working paper, 19233.

Ferrie, J., Rolf, K., and Troesken, W. (2014) Lead Exposure and the Perpetuation of Low Socioeconomic Status. Working paper.

Field, E., Robles, O., and Torero, M. (2009) Iodine Deficiency and Schooling Attainment in Tanzania. American Economic Journal: Applied Economics, 1(4): 140-169.

Figlio, D., Guryan, J., Karbownik, K., and Roth, J. (2014) The Effects of Poor Neonatal Health on Children's Cognitive Development. American Economic Review, 104(12): 3921-3955.

Fiszbein, A. and Schady, N. (2009) Conditional Cash Transfers: Reducing Present and Future Poverty. The World Bank, Washington D.C.

Fitzsimons, E. and Vera-Hernandez, M. (2014) Food for Thought? Breastfeeding and Child Development. University of London Working paper, 14-04.

Fryer, R., Levitt, S. and List, J. (2015) Parental Incentives and Early Childhood Achievement: A Field Experiment in Chicago Heights. NBER Working paper, 21477.

Garces, E., Currie, J., and Thomas, D. (2002) Longer Term Effects of Head Start. American Economic Review, 92(4): 999-1012.

Gelber, A.M. and Isen, A. (2013) Children's Schooling and Parents' Investment in Children: Evidence from the Head Start Impact Study. Journal of Public Economics, 101: 25-38.

Gertler, P., Heckman, J.J., Pinto, R., Zanolini, A., Vermeersch, C., Walker, S., Chang, S.M., and Grantham-McGregor, S. (2014) Labor Market Returns to Early Childhood Stimulation: a 20-year Followup to an Experimental Intervention in Jamaica. Science, 344(6187): 998-1001.

Greve, J., Schultz-Nielsen, M.L. and Tekin, E. (2015) Fetal Malnutrition and Academic Success: Evidence from Muslim Immigrants in Denmark. NBER Working paper, 21545. 
Grossman, M. (1972) On the Concept of Health Capital and the Demand for Health. Journal of Political Economy, 80(2): 223-55.

Golberstein, E., Gonzales, G., and Meara, E. (2016) Economic Conditions and Children's Mental Health. NBER Working paper, 22459.

Gould, E., Lavy, V., and Paserman, D. (2011) Fifty-five Years after the Magic Carpet Ride: The Long-Run Effect of the Early Childhood Environment on Social and Economic Outcomes. Review of Economic Studies, 78(3): 938-973.

Gunnsteinsson, S., Adhvaryu, A., Christian, P., Labrique, A., Sugimoto, J., Shamin, A.A., and West Jr., K.P. (2016) Resilience to Early Life Shocks - Evidence From the Interaction of a Natural Experiment and a Randomized Control Trial. Working paper.

Gutierrez, F. (2014) Long-Term Consequences of Early Life Health Shocks: Evidence from the 1980s Peruvian Crisis. Working paper.

Havnes, T. and Mogstad, M. (2011) No Child Left Behind: Subsidized Child Care and Children's Long-Run Outcomes. American Economic Journal: Economic Policy, 3(2): 97-129.

Havnes, T. and Mogstad, M. (2015) Is Universal Child Care Leveling the Playing Field? Journal of Public Economics, 127: 100-114.

Heckman, J.J. (2007) The Economics, Technology, and Neuroscience of Human Capability Formation. PNAS, 104(33), 13250-13255.

Heckman, J.J. (2008) Schools, Skills and Synapses. Economic Inquiry, 46(3): 289-324.

Heckman, J. and Kautz, T. (2014) Fostering and Measuring Skills: Interventions that Improve Character and Cognition. In The Myth of Achievement Tests: The GED and the Role of Character in American Life, edited by Heckman, J., Humphries, J.E., and Kautz, T. Chicago, IL: University of Chicago Press. pp. 341-430.

Heckman, J.J., Pinto, R., and Savelyev, P. (2013) Understanding the Mechanisms through Which an Influential Early Childhood Program Boosted Adult Outcomes. American Economic Review, 103(6), 2052-2086.

Hoffman, A.B. (2014) Adverse In Utero Experiences and Distortions of the Sex Ratio: Evidence from Prenatal Fasting. Working paper.

Hoynes, H, Miller, D., and Simon, D. (2015) Income, the Earned Income Tax Credit, and Infant Health. American Economic Journal: Economic Policy, 7(1): 172-211.

Hoynes, H., Whitmore Schanzenbach, D., and Almond, D. (2016) Long Run Impacts of Childhood Access to the Safety Net. American Economic Review, 106(4): 903-934. 
Hsin, A. (2012) Is biology destiny? Birth-weight and Differential Parental Treatment. Demography, 49(4): 1385-405.

Isen, A., Rossin-Slater, M. and Walker, R. (2015) Every Breath You Take - Every Dollar You'll Make: The Long-Term Consequences of the Clean Air Act of 1970. Forthcoming at the Journal of Political Economy.

Jayachandran, S., Lleras-Muney, A., and Smith, K.V. (2010) Modern Medicine and the 20th Century Declines in Mortality: New Evidence on the Impact Of Sulfa Drugs. American Economic Journal: Applied Economics, 2(2): 118-146.

Kline, P. and Walters, C. (2016) Evaluating Public Programs with Close Substitutes: The Case of Head Start. The Quarterly Journal of Economics, doi: 10.1093/qje/qjw027.

Knittel, R.C., Miller, L.D., and Nicholas, J.S. (2011) Caution, Drivers! Children Present: Traffic, Pollution, and Infant Health. Review of Economics and Statistics, 98(2): 350-366.

Kremer, M. and Miguel, E. (2004) Worms: Identifying Impacts on Education and Health in the Presence of Treatment Externalities. Econometrica, 72(1): 159-217.

Krutikova, S. and Lilleør, H.B. (2015) Fetal Origins of Personality: Effects of Early Life Circumstances on Adult Personality Traits. Working paper.

Lavy, V., Schlosser, A., and Shany, A. (2016) Out of Africa: Human Capital Consequences of In Utero Conditions. NBER Working paper, 21894.

Lindo, J.M. (2011) Parental Job Loss and Infant Health. Journal of Health Economics, 30: 869879.

Lee, C. (2014) Intergenerational Health Consequences of In Utero Exposure to Maternal Stress: Evidence from the 1980 Kwangju Uprising. Social Science \& Medicine, 119(C): 284-291.

Linnemayr, S. and Alderman, H. (2011) Almost Random: Evaluating a Large-scale Randomized Nutrition Program in the Presence of Crossover. Journal of Development Economics, 96(1): 106-14.

Lleras-Muney, A. (2010). The needs of the Army: Using Compulsory Relocation in the Military to Estimate the Effect of Environmental Pollutants on Children's Health. Journal of Human Resources, 35(3): 549-590.

Løken, K.V., Mogstad, M., and Wiswall, M. (2012) What Linear Estimators Miss: The Effects of Family Income on Child Outcomes. American Economic Journal: Applied Economics, 4(2): 1-35.

Ludwig, D.S., Rouse, H., and Currie, J. (2013) Pregnancy Weight Gain and Childhood Body Weight: A Within-Family Comparison. PLOS Medicine, 10(10). 
Malamud, O., Pop-Eleches, C. and Urquiola, M. (2016). Interactions between Family and School Environments: Evidence on Dynamic Complementarities? NBER Working paper, 22112.

Manski, C.F. (2011) Genes, Eyeglasses, and Social Policy. Journal of Economic Perspectives, 25(4): 83-94.

McCrary, J. and Royer, H. (2011) The Effect of Female Education on Fertility and Infant Health: Evidence from School Entry Policies Using Exact Date of Birth. American Economic Review, 101(1): 158-195.

Meckel, K. (2015) Is the Cure Worse than the Disease? Unintended Consequences of Fraud Reduction in Transfer Programs. American Economic Review, $R \& R$.

Milligan, K. and Stabile, M. (2011) Do Child Tax Benefits Affect the Well-Being of Children? Evidence from Canadian Child Benefit Expansions. American Economic Journal: Economic Policy, 3(3), 175-205.

Meyer, B. and Wherry, L. (2016) Saving Teens: Using a Policy Discontinuity to Estimate the Effects of Medicaid Eligibility. Journal of Human Resources, 51(3): 556-588.

Miller, S. and Wherry, L. (2014) The Long-term Health Effects of Early Life Medicaid Coverage. Working paper.

Nilsson, J.P. (2015) Alcohol Availability, Prenatal Conditions, and Long-Term Economic Outcomes. Forthcoming at the Journal of Political Economy.

Oizer, O. (2014) Exploiting Externalities to Estimate the Long-Term Effects of Early Childhood Deworming. World Bank Working paper.

Persson, P. and Rossin-Slater, M. (2016) Family Ruptures and Intergenerational Transmission of Stress. Forthcoming at the American Economic Review.

Quintana-Domeque, C. and Rodenas-Serrano, P. (2016) The Hidden Costs of Terrorism: The Effects on Human Capital at Birth. Journal of Human Resources, R\&R.

Robinson, J.J. (2012) The Effects of Asymmetric and Symmetric Fetal Growth Restriction on Human Capital Development. Working paper.

Rocha, R. and Soares, R. (2014) Water Scarcity and Birth Outcomes in the Brazilian Semiarid. Journal of Development Economics, 112: 72-91.

Rosales, M.F. (2015) Impact of Early-Life Shocks on Human Capital Formation: Evidence from El Nino Floods in Ecuador. Working paper. 
Rossin-Slater, M. (2013) WIC in Your Neighborhood: New Evidence on the Impacts of Geographic Access to Clinics. Journal of Public Economics, 102: 51-69.

Rossin-Slater, M. (2011) The Effects of Maternity Leave on Children's Birth and Infant Health Outcomes in the United States. Journal of Health Economics, 30(2): 221-239.

Rossin-Slater, M. (2016) Signing Up New Fathers: Do Paternity Establishment Initiatives Increase Marriage, Parental Investment, and Child Well-Being? Forthcoming at the American Economic Journal: Applied Economics.

Rossin-Slater, M. and Wust, M. (2015) Are Different Early-life Investments Complements or Substitutes? Long-Run and Intergenerational Evidence from Denmark. Working paper.

Royer, H. (2009) Separated at Girth: US Twin Estimates of the Effects of Birth Weight. American Economic Journal: Applied Economics 1(1): 49-85.

Sanders, N.J. (2012) What Doesn't Kill you Makes you Weaker Prenatal Pollution Exposure and Educational Outcomes. Journal of Human Resources, 47(3): 826-50.

Scholte, R., van den Berg, G.J., Lindeboom, M. (2015) Long-Run Effects of Gestation During the Dutch Hunger Winter Famine on Labor Market and Hospitalization Outcomes. Journal of Health Economics, 39: 17-30.

Schwandt, H. (2016) The Lasting Legacy of Seasonal Influenza: In-utero Exposure and Human Capital Development. Working paper.

Shah, M. and Steinberg, B.M. (2016) Drought of Opportunities: Contemporaneous and Long Term Impacts of Rainfall Shocks on Human Capital. Forthcoming at the Journal of Political Economy.

Simon, D. (2016) Does Early Life Exposure to Cigarette Smoke Permanently Harm Childhood Health? Evidence from Cigarette Tax Hikes. American Economic Journal: Applied Economics, 8(4): $128-159$.

Sievertsen, H.H. and Wust, M. (2015) Discharge on the Day of Birth, Parental Response and Health and Schooling Outcomes. Working paper.

Van den Berg, G.J., Lindeboom, M., and Portrait, F. (2006) Economic Conditions Early in Life and Individual Mortality. American Economic Review, 96(1): 290-302.

Venkataramani, A.S. (2012) Early Life Exposure to Malaria and Cognition in Adulthood: Evidence from Mexico. Journal of Health Economics, 31(5): 767-780.

von Hinke Kessler Scholder, S., Wehby, G.L., Lewis, S., and Zuccolo, L. (2014) Alcohol Exposure in Utero and Child Academic Achievement. The Economic Journal, 124(576): 634-667. 
Ward, C. and Phipps, S. (2014) Influenza, the In Utero Environment, and Developmental Outcomes of Pre-school Children. Working paper.

Wernerfelt, N., Slusky, D., and Zeckhauser, R. (2016) Second Trimester Sunlight and Asthma: Evidence from Two Independent Studies. Forthcoming at American Journal of Health Economics.

Wherry, L., Miller, S., Kaestner, R., and Meyer, B. (2015) Childhood Medicaid Coverage and Later Life Health Care Utilization. NBER Working paper, 20929.

Yi, J., Heckman, J.J., Zhang, J., and Conti, G. (2015) Early Health Shocks, Intra-household Resource Allocation, and Child Outcomes. Economic Journal 125 F347-F371. 


\section{Panel A: Nutrition Shocks}

Adhvaryu et al. (2016) Effects of

introduction of iodine fortification educ, wages, $\mathrm{N}=418,791$ obs.

the $25-55$ education and

labor market outcomes.
1) Census 1950-1980 that provide data DD: Compare cohorts exposed in-utero (1920-1927) to iodized salt with those slightly older (\& unexposed) (1928-1931) across states with high vs. low iodine deficiency rates prior to the salt fortification.

Models includer year dummies, \& year of birth FE \& region of birth FE using 9 Census Bureau divisions.

Almond and Mazumder (2011) Effects of exposure to Ramada Exploit the timing (month) of Ramadan as a
natural experiment in diurnal fasting and

fasting on birth outcomes and adult Ages 20-39

disability, education, and mortality in Uganda 2002; $\mathrm{N}=80,000$ (Muslims: Michigan, Iraq, and Uganda.
1) Census data for: fetal health.

DD model: compare Muslim outcomes (treatment) to non-Muslim outcomes (control).

2) Michigan Natality data, universe of births, 1989-2006, N 2.5M birth records.

Identifying assumption: pregnancies are not timed relative to Ramadan along

Labor force participation: $+1.35 \mathrm{pp}(2.2 \%=0.03$ of a SD) (women: 1.63pp). women: salt iodization accoun No significant effects on education. Income quintiles: the likelihood of being in the 2nd Effects on LFP were larger in the wage income quantile rose by 0.35 to $0.68 \mathrm{pp}$ more 1 st $\& 2$ nd income quintiles: effect $=$ during and after the roll out of iodized salt in high $1 \mathrm{pp}$ goiter compared to in low goiter states. unobserved determinants of health.

Models include controls for month of $\mathrm{FE}$, geographic location $\mathrm{FE}$, and rich individual controls (estimates are ITT).

Almond, Mazumder, and Van Ewijk (2015). Effect of exposure to Ramadan fasting in utero on age 7 schooling attainment in England.

\section{1) England's Register data "Key Stage 1 DD strategy: authors take the effect on} scores", students' academic performance for those who attend state schools, 1998-2007.

2) Pupil Level Annual School Census (PLASC), covers all enrolled pupils in each year, includes demog \& socioeconomic characteristics including ethnicity.

Authors link data on the Key Stage 1 scores to the PLASC for e/year using unique student identifier from 2002 onwards and a 2-step matching process prior to 2002. $\mathrm{N}=326,592$ obs.

\section{Muslims and use and non-Muslims to} control for possible seasonal effects. Design exploits the fact that Ramadan moves through the calendar. Control Odels include child' YOB FE, cubic time trend of the $N$ days between the DOB \& January 1, 1960. Authors also fully interact each regressor (except for the geographic FE) w/a dumm for Muslim. group: Caribbean students. xposure to Ramadan:

$\mathrm{BW}=-18 \mathrm{gr}$ for Arab-named pregnancies $(-0.6 \%)$. Effects by trimester: $-21,-26,0$ grams, effects by month: -40 grams in first 2 months of pregnancy $\&$ in months 5 th $/ 7$ th significant effects. Adult disability: $+22 \%$ (eff. in 1st month only, driven by mental or learning disabilities.) Mortality: "due to aging" $+0.37 \mathrm{pp}(\sim+70 \%$ wrt the mean).

Most of the estimated effect of early pregnancy exposure is in the middle of the distribution. No gradient in BW by maternal education, Medicaid use, or month prenatal care was initiated.

Effect sizes are similar in Uganda and Iraq.

Wealth: -2.6pp, -2.1pp less likely to own a home (males only). ion: no effects.

Test scores (math, reading, \& writing "Key Stage 1"):

0.05 to -0.08 of a SD.

By months of pregnancy:

Math: $-0.068,-0.059,-0.081$ of a SD in 1 st, 2 nd, \& 3 rd months of pregnancy (no effects in other months).

Reading: $-0.054,-0.067,-0.073 \mathrm{SD}$.

Writing: $-0.052,-0.053,-0.055$ SD .

Effects rise monotonically over the course of the $1 \mathrm{st}$

Estimates are downward biased to the extent that

Ramadan is not universally observed. 


\section{Panel A: Nutrition Shocks}

Feyrer, Politi, and Weil (2013). Effect 1) Statistics from draft physicals for of introducting iodine fortification in WWI, include info. on the incidence of the U.S. in 1924 on military skill levels goiter prior to treatment for 151 (young adult males) and thyroid related deaths.

2) Dataset of men who enlisted in the

Compare cohorts born just before \& after Individuals born in 1925 \& 1926 (introduction of iod. NA iodized salt introduced in 1924.Two salt was in 1924):

sources of variation: i) pre-existing (<1924) Prob(being assigned to Air Forces- indicator of high iodine deficiency; ii) timing of the intervention.

skill): +0.3 to $0.6 p p$ (full sample); $+2.5-8.7 p p$ (individuals in initially high goiter areas). Army during WWII; indicates who was drafted into the Air Force (highly

Also exploit the fact that the Air Force was (han Ground Forces. This non-random based on an Army General Classif. Test assignment is key for identification (AGCT), source: National Archives \& strategy. Records Administration $\mathrm{N}=2$ million records in 1938 - 1946. groups more affected because they were iodine deficient for a longer period). Note: In 1926 death rates were $>6$ times as high for women as for men though sample is male.

Linear Prob (\& Logit) Models include interaction of goiter in 1924 in region of birth * YOB dummies, YOB dummies * enlistment year dummies, enlistment month dummies

\begin{tabular}{ll}
\hline Fitzsimons and Vera-Hernandez & UK Millenium Cohort Study; 9 months \\
(2013). Effect of breast-feeding in the & (2000/2001), 3 years (2004/05), 5 years \\
U.K. on cognition and health at age 7. & (2006), 7 years (2008). Data includes \\
& hour of child's birth.
\end{tabular}
Instrumental variables: Exploit timing in

day of the week children are born (children on cognitive development, but NOT on noncognitive born on weekend or just before, are less skills or physical health.

likely to receive breast feeding support Breastfeeding: $\mathrm{N}=18,500$ babies born (sample excludes services) Cognitive dev index: +0.6 of a SD

C-section deliveries). IV: instrumental variable is being born on

Authors corroborate data w/Maternity weekend.

Users Survey a postal survey conducted on 26,000 mothers, 3 months after birth.

\begin{tabular}{|c|c|c|}
\hline $\begin{array}{l}\text { Greve, Schultz-Nielsen, and Tekin } \\
\text { (2015). Examine the effect of } \\
\text { Ramadan fasting on student } \\
\text { outcomes in Denmark. }\end{array}$ & $\begin{array}{l}\text { 1) Danish administrative records on } \\
\text { Danish, English, Math, \& Science test } \\
\text { scores in 9th grade. } \\
\text { 2) Danish birth registry, which includes } \\
\text { exact info on gestation length and birth } \\
\text { date } \\
N=11,291 \text { children. }\end{array}$ & $\begin{array}{l}\text { DD: exploit the overlap between time in } \\
\text { utero of children born in Denmark with the } \\
\text { month of Ramadan. } \\
\text { Treatment group: children born to } \\
\text { immigrant parents from predominantly } \\
\text { Muslim countries } \\
\text { Control group: children born to immigrant } \\
\text { parents from predominantly NON-Muslim } \\
\text { countries. }\end{array}$ \\
\hline
\end{tabular}

Child is Muslim*Child was exposed to Ramadan: No overall effects on Danish, English, Math or Science test scores. Authors estimate models by gender \& by gender-SES.
Estimates are larger for girls and for children of lower socioeconomics status mothers. Danish test scores: -1.08 SD (females and low SES children). English test scores: -1.84 SD; -1.6 SD (females and low SES children). Math test scores: -1.04 SD; -0.98 $\mathrm{SD}$ (males and low SES children). 


\section{Panel A: Nutrition Shocks}

Hoffman (2014). Effects of Ramadan DHS data from 7 Muslim countries, Fasting in 7 Muslim countries on sex $1987-2013 ; \mathrm{N}=275,627$ births. ratios of 0-60 month olds.
Exploit variation in the timing of Ramadan Exposure to Ramadan during pregnancy: throughout the year, across countries. Prob(child is a girl): $+2.4 \%$ (+ $0.024 \mathrm{SD})$.

Treatment group: individuals exposed to Exposure to Ramadan in the first 3 months of Ramadan (at least 1 month) during gestation, controls not exposed.

Models include month of birth, year of birth, \& country FE, \& country-specific time trends, mother's FE.

pregnancy:

Prob(miscarriage): $+1 \%$ (0.004 SD).

No effects on neonatal death or infant death.
Effect of nutritional supplementation in 212 villages, includes info on health control villages.

in Senegal on weight for age for children 0-3.

status of ch

follow-up in 2006. $\mathrm{N}=200,000$

households.

as an instrument for actual treatment.

3) Propensity score matching across

treatment and control villages.

Models include initial village-leve

characteristics (e.g., distance to the next

village), interactions of village

characteristics and planned treatment

dummies for child age.

Ludwig, Rouse, and Currie (2013). 1) Vital Statistics Natality data: universe 1) Exclude pre \& post terms, multiple

Maternal weight gain during of births in Arkansas 1989-2005,

pregnancy and child BMI in Arkansas. N=42,133 women (91,045 offspring).

2) State mandated data on childhood

BMI from public schools (August 18,

2003 to June 2, 2011).

von Hinke Kessler Scholder et al, 1) Avon Longitudinal Study of Parents and Children (ALSPAC); Panel follows cohort born in Avon, England in 1991 1992. $\mathrm{N}=4,088$ children gestational $N$, maternal diabetes, \& extremes in BW's.

2) incorporate measured confounders in models.

3) Sibling FE design.

Models include rich maternal controls,

month of child's age \& year of birth $F$.

effects of maternal alcoho

consumption during pregnancy. at a population level,

genetic variants are unrelated to

the National Pupil Database a census of socioeconomic characteristics.

all pupils and measured at 7,11,14, and Instrument: dummy for whether an

of the rare allele.

Models control for child's genotype on the

same variant, and for the ancestry-

informative principal components.
Weight-for-age:

Using DD model: +0.1 SD

Using IV: +0.31

Using PSM: +0.27 SD

Effects somewhat larger in rural

areas and in mothers without

primary education.

e.g., for less educated mothers:

$\mathrm{P}$ (child is a girl): $+3.4 \%(+0.035 \mathrm{SD})$

$\mathrm{P}$ (misscarriage): $+1.7 \%$ (+0.017 SD)

$P$ (neonatal death): no effect

$P($ infant death): $1.4 \%$ (0.014 SD)

(driven by exposure to Ramadan in

the month of birth).

By child's age: authors find

significant weight gain for younger

children (these children were impacted in utero).

Most malnutrition occurs by 18 months w/limited catch-up after that."

One additional Kg of pregnancy weight gain:

NA

Childhood BMI: $+0.022(0.06 \%=0.004$ of a SD)

Childhood overweight/obesity: OR increased by

1.007 .

Variations in pregnancy weight gain accounted for a

$0.43 \mathrm{~kg} / \mathrm{m} 2$ difference in childhood BMI.

Exposure to an additional unit of alcohol

Estimates are slightly larger for

(instrumented by mother having the rare allele):

children of lower education and

1st stage: Mothers who carry the rare allele are -11 lower income mothers. No

to $-15 p p$ less likely to consume any alcohol during difference by gender or partner's

pregnancy (-53\% w.r.t. the mean)

social class at birth.

Key Stage examination test scores (at ages 7, 11, 14,

16): -0.2 to $-0.3 \mathrm{SD}$ (no mean stats provided to 


\section{Panel B: Stress}

\section{Aizer (2011). Impact of}

domestic violence on birth

outcomes in California.

Hospital admissions for assault

2 challenges: i) possible omitted variables bias,

during pregnancy in CA, 1991-2002 ii) non-random under-reporting of domestic

matched with universe of births in violence.

CA.

$\mathrm{N} \sim 500,000$ pregnant women/yr.

Author uses: i) IV: A control function where IV is

the enforcement of laws against domestic

As criminal sanctions increase,

NA

domestic violence declines.

Using control func. method:

violence across jurisdictions, ii) Matching

BW: -163gr due to hospitalization for an

estimates on many covariates ( $n=1,542$ women Effects of violence on BW are larger in 1st

matched).

(OLS models predict

a BW decline of -161gr).

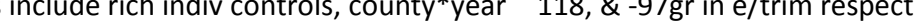

dummies, a quadratic in year, county FE for the Using matching: $\mathrm{BW}=-159 \mathrm{gr}$

5 largest counties in CA.

Aizer, Stroud, and Buka (2016). Examine

relationship between

measured cortisol levels

during 3rd trimester and

education at age 7 .
National Collaborative Perinatal Project (NCPP); mothers cortisol levels were measured in 3rd trim and their children were followed up

to age 7; years of birth: 1959 to

1965, sample used in study are 2

cities: Boston and Providence.

$\mathrm{N}=1,093$ pregnancies (368 siblings).
Regression model w/indicator of cortisol exposure in pregnancy and rich individual controls and sibling FE.
Being exposed to highly elevated cortisol in- Children born to mothers utero:

Education: -0.39 to -1.1 yrs of schooling ( 0.58 of a SD) (sibling FE) without a HS degree \& exposed to highly elevated cortisol in-utero:

Education: -2 yrs of schooling (sibling FE). No effect among children of more educ moms.

Currie and Rossin-Slate

1) Vital statistics, 1996-2008,

Exploit the temporal \& geographic variation in Exposure to hurricanes:

(2013). Effect of stress due includes info on mothers' names,

to potential hurricane

DOB, \& residential addresses (helps

the ocurrence of hurricanes in Texas. Mother FE

exposure during pregnancy identify mothers who were in the

on infant health outcomes

in Texas.

path of major tropical storms \&

hurricanes), child's exact DOB

county of birth

$\mathrm{N}=1,270,441$ birth

(to account for mother's time invariant

No effects on LBW or gestation.

characteristics)

with IV to account for a mother's endog.

Prob. of abnormal cond.: $+60 \%$ (including

migration in response to a hurricane. Instrument Prob. of having complications during

is a mother's county of residence in 1 st labor/delivery: $+30 \%$.

2) Data on hurricanes come from

the Weather Underground

Hurricane Archive; publicly

available. 
Table 1: Effects of Mild Early Life Shocks on Future Outcomes

\section{Study \\ Micro - Data, N \\ Identification strategy and specification}

Effects of the shock

Heterogeneity in

mechanisms/effects

\section{Panel B: Stress}

\section{Lee (2014).}

Intergenerational effect

stress mother suffered

while in utero (due to

Kwangju uprising in Korea)

on her children's birth

outcomes 20 to 22 years

later.

Persson and Rossin-Slater (2016). Asks how death family member during pregnancy affects

birthweight, mental and physical health, up to age 30 .

) 2001, \& 2005. Link child to hospitalizations, and income Review cause of death register for
1) Korean vital statistics, 2000 \&

1) Korean vital statistics, 2000 \&

Natural experiment: Massacre of $>500$ civilians and wounding of 3000 in the Kwangju (KU),

Korea in 1980.

DD: Assume that individuals whose mother resided in Kwangju in May 1980 \& who were born between June 1980 \& February 1981 were exposed to stress caused by the violence in

utero. Models include cubic time trends, and rich mother controls.

1) Universe of children in Sweden in Exploit the quasi-random variation in the exact $1973,1977,1983,1988,1995,1999$, timing of bereavement relative to the child's expected date of delivery at full-term.

Models include year \& month of conception FE, Uses prescription drug: $+6 \%$ (No standard maternal great-grandparents. conception of child FE.

Riew cause of death register fo all family members, combine with information about child's exact DOB, birth outcomes and later health outcomes as well as income and taxation register with labor income up to age $30 . \mathrm{N}=63,756$ obs. pregnancy:

BW: -37grams (-1.1\%) (1st trim), -105

grams $(-3.2 \%)(2 n d)$, no effect (3rd trim) LBW: $+1.7 \%$ (1st trim), $+4.0 \%$ (2nd trim),

$+1.3 \%$ (3rd trim)

Preterm: no effect (1st trim), $+4.6 \%$ (2nd

trim), $+1.5 \%$ (3rd trim)

In-utero exposure to the death of a

relative:

Uses prescription drug: $+6 \%$ (No
deviations of ouctomes provided)

Uses anti-anxiety drugs: $11 \%$

Uses anti-depression drugs: $9 \%$

Daily dose of ADHD med.: $23 \%$

by lower tail of distrib)

LBW: +20\%; VLBW: +30\%; Preterm: +15\%

No significant effects on physical health or income. grandparents, aunts and uncles and \& municipality where a mother lived at

\section{Exposure to the KU shock by trimester of}

BW: $-18 \mathrm{gr}(-0.5 \%=-0.03$ of a SD) (eff driven

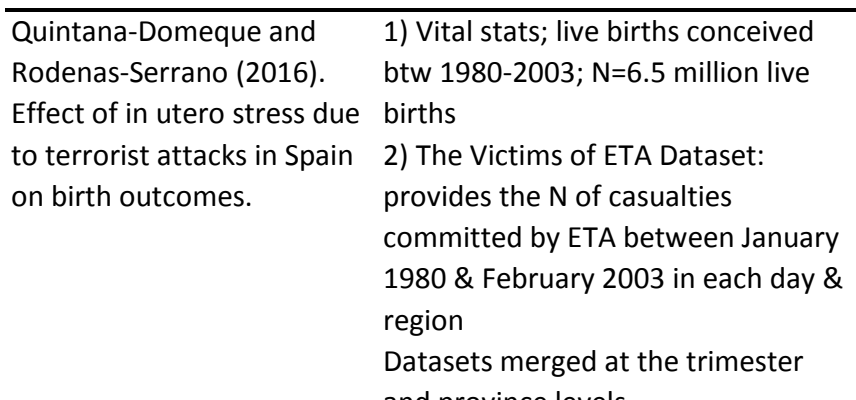

DD: exploit the variation in casualties accross provinces (50 geographical regions) \& monthsyears (more than 275 conception month-years)

1 additional bomb casualty in

the 1st trimester of pregnancy:

By gender: no differential

BW: -0.7grams (-0.02\%) (no standard

effect for both boys and

deviations provided in Table 1 )

Models include mother's province of residence Prematurity: +0.9 per 1,000 live births (girls (results not shown)
$0.02 \%$

Normality: 0.6 per 1,000 live births.

Results are driven by exposure to terrorism

in the 1st trimester. and province levels. 


\section{Study

\section{Panel C: Disease}

\section{Almond, Currie, U.S. vital statistics natality \&}

and Hermann mortality records: authors are able

(2011). Effect of to link the post-neonatal mortality

disease rates in the mother's state of birth

environment as \& provide info on outcomes of

proxied by mother \& infant.

postneonatal

mortality rates $1989-2006, N^{\sim} 3.5-4$ million

on the health of births/yr

women 2) Mortality microdata, 1960 -

observed in the 1991.

U.S. vital

statistics natality

data.

\begin{tabular}{ll}
\hline Baird, Hicks, & 1) Longitudinal data from 75 rural \\
Kremer, and & schools treated 1998-2001.
\end{tabular}

Kremer, and schools treated 1998-2001.

Miguel (2016). 2) Kenya Life Panel Survey (KLPS)

Effects of 2007-2009, tracked $\mathrm{N}=7,500$

deworming on respondents who had been enrolle

test scores and in grades 2-7 in the 75 treated

anthropometrics schools at baseline in 1998.

of 8-15 year old

children in

Kenya.
Exploit the geographic \& temporal variation An additional postneonatal death per 1,000 in the Larger impacts for blacks

in post-neonatal mortality rates (across racial year after mother's YOB:

groups) from 1960 to 1990 in 5 large states. Health:

Aggregate data into cells by mother's state Diabetes: $1.8 \%(0.009$ of a SD); $1.4 \%=0.007$ of a and $\mathrm{YOB}$, age, and race, and child's state and SD (whites), $3.5 \%=0.012$ of a SD (blacks). YOB.

Hypertension: no effects

SES:

race, state of birth, in YOB \& yr, state, age Educ attainment: $-0.1 \%$ (-0.012 of a SD) that mother gave birth) include mother Married: $-0.6 \%(-0.009$ of a SD)

characteristics, mother's state of birth FE, Maternal behav: smoking $+2 \%$ (-0.02 of a SD); high by

child's YOB *child's state FE, maternal single weight gained $1.7 \%$ ( 0.01 of a SD). almost $30 \%$ for blacks year age $\mathrm{FE}$, mother's state of birth linear time trends, linear time trends in maternal age FE.

Reduced form model: includes dummy for Health: Self-reported health is v. good: $+4.1 \mathrm{pp}(+$ treatment, $\mathrm{N}$ of treatm pupils in $6 \mathrm{Km}, \& \mathrm{~N}$ of 0.085 of a SD); Prob of miscarriage: $-2.7 \mathrm{pp}(-0.69$ treatm schools in $6 \mathrm{Km}$ \& baseline indiv \& school characteristics.

of a SD) (females only).

Education: yrs of schooling $+0.3(+0.10$ of a SD),

English vocab. tests +0.076 of a SD.

of pupils attending deworming treatment Labor market outcomes: work hours: $+1.76 \mathrm{hrs}=$ schools within $6 \mathrm{Km}$, conditional on total $\mathrm{N}$ of $12 \%(+0.12$ of a SD); wages: +30.1 log points = primary school pupils within $6 \mathrm{Km}$.

\section{$3.8 \%(0.36$ of a SD).}

Shifts in employment towards full-time jobs with higher wages (i.e., manufacturing) (males) \& away from casual labor \& domestic services (females). than for whites.

The mean PNMRt+1 for

whites (4.0) and the mean PNMRt+1 for blacks (8.4) suggest that the early life disease environment increased the probability of diabetes during pregnancy compared to $5.6 \%$ for whites.

No differences in labor supply effects by gender or by age or by initial infection rate. Externality effects: an increase of 1SD in local density of treatment school pupils (917 pupils= treating $20 \%$ of local primary school pop), leads to: +3 hours worked/wk

\begin{tabular}{ll}
\hline Beach, Ferrie, & 1) Census data of 1900 \& of 1940. \\
Saavedra, and & 2) City-year level typhoid fatality \\
Troesken (2016). & rates for 75 cities (source: Whippl \\
Typhoid rates in & (1908); 10th annual Census \\
3-yr MA around & mortality statistics). \\
birth on adult & $\mathrm{N}=189,515$ obs. \\
education and & \\
earnings. &
\end{tabular}

Exploit variation in typhoid fatality rates during early life as a proxy for water quality. Instrument typhoid fever using lagged citylevel typhoid rates that lie upstream). "Cities that dump their sewage into a river will increase future typhoid rates for cities downstream."

Models include controls for being black, city \& year of birth FE, birth order FE. 1st stage: Lagged typhoid rates in the feeder city NA are a strong predictor of typhoid rates in the receiving city (F-stat $>517.81)$. Educational attainment: +1 month of schooling (OLS) $(0.9 \%=0.026$ of a SD) (no effect obtained from IV). Earnings: $+1 \%$ (OLS) ( 0.012 of a SD); $+9 \%$ (IV) $(0.10$ of a SD). No effect on home owning. 


\section{Study

\section{Panel C: Disease}

\section{Bhalotra and \\ 1) Mexican Family Life Survey}

Venkataramani

(2013). Effects

of diarrheal

disease on test

scores of

children in

(MxFLS), $\mathrm{N}=8,500 \mathrm{HHs}$ in 150

communities in 16 states, waves:

2001-2002; includes month \& yea

of birth, birth state, indicators of

$\mathrm{HH}$ wealth, parental investment.

2) PISA Test score data: waves 15.

in 1987/1988, 1990, \& 1993 .

includes school quality, parental investments. from IPUMS (to study empl. \& occup. trends by gender).
Mexico at age 9- 2003, 2006 \& 2009 for cohorts born

3) Census micro-data 1960-2000
Reduction in the risk of waterborne disease from a major water reform in Mexico in 1991.

Reform introduced suddenly in reaction to threat of cholera in neighboring countries. Exploit state*yr variation in program intensity. control disease un affected by the reform but gap smaller than the OECD avg gap: 11 in 500 a leading cause of child morbidity \& points). mortality.

ITT estimates identifying assumption:

test scores are uncorrelated $\mathrm{w} /$ the timing of

the water reform

Models include indiv controls in pre-

$1991^{*}$ dummy Post, state \& year of birth FE, state time trends.

\begin{tabular}{ll}
\hline Bhalotra and & 1) US Census micro data for 1980- \\
Venkataramani & 2000; authors focus on men only \\
$\begin{array}{ll}\text { (2015). Examine } & \text { who were born born between 1930- } \\
\text { the impacts of } & \text { 1943; N=2,018,898 men (of which } \\
\text { pneumonia in } & \text { less than 10\% are Blacks). }\end{array}$
\end{tabular}

infancy on adult

(males)

education,

employment,

disability,

income and

income mobility.
Exploit state variation in 1937 in the

introduction of sulfa antibiotics to prevent

pneumonia. Treatment group: cohorts in

their infancy in 1937 or later. Control group:

cohorts in their infancy before 1937.

Models include an interaction betw

pre-sulfa pneumonia mortality rate in the Work-related disability: $-0.6 \%$

birth state in 1930-1936) * (Dummy for

Employment: $+0.4 \%$

cohorts who were in their infancy in 1937 or Income: $+1.5 \%$

later)

Models include indiv controls, birth state \&

birth year varying observables, state linear

Having income in the lowest quintile: $-0.47 \%$

time trends.
1 SD reduction in childhood diarrhea mortality rates:

Test scores (Raven): +0.1 of a SD (0.6\%) (girls only)

Reading: 0.04 of a SD (+0.7\%) (girls only)

Math: 0.05 of a SD (+0.8\%) (girls only)

A 1 SD decrease in diarrheal mortality rates in childhood reduces gender gap by $80 \%$ (MX gender

Effects are driven by low SES girls.

A 1 SD decline in pneumonia exposure in the birth By levels of institutionalstate due to the introduction of antibiotics: racial segregation: "Black Years of schooling: +0.1 (no SD provided in paper) men born in the least segregated states reaped substantial gains from infant exposure to sulfa drugs, while blacks born in the more segregated states saw muted gains". 


\section{Study

\section{Panel C: Disease}

\begin{tabular}{|c|c|c|c|}
\hline $\begin{array}{l}\text { Currie and } \\
\text { Schwandt } \\
\text { (2013). Shows } \\
\text { that there is } \\
\text { seasonality in } \\
\text { health at birth } \\
\text { within mother } \\
\text { and that this } \\
\text { may reflect } \\
\text { seasonal flu }\end{array}$ & $\begin{array}{l}\text { 1) Vital Statistics Natality data in NJ } \\
\text { (1997-2006), NYC (1994-2004), \& } \\
\text { PA (2004 -2010). } \\
N=647,050 \text { pairs of siblings } \\
(1,435,213 \text { children). } \\
\text { 2) Info. on prevalence of Influenza } \\
\text { is obtained from the Center for } \\
\text { Disease Control (1997-onward). }\end{array}$ & $\begin{array}{l}\text { Analyze the seasonality of health at birth by } \\
\text { comparing siblings conceived by the same } \\
\text { mother at different times using sibling FE. } \\
\text { Compare impact of coming to term in early } \\
\text { winter in high flu and low flu years. }\end{array}$ & $\begin{array}{l}\text { Conception from Jan. to May is associated with } \\
\text { significant reductions in gestation (-0.08 week) } \\
\text { and prematurity within families: } \\
+1 \mathrm{pp}(13.2 \%) \text {. Birth weight falls by }-4 \mathrm{gr} \text { (increases } \\
\text { by } 8 \mathrm{gr} \text { if conception occurs in June-August). More } \\
\text { severe flu seasons show stronger effects. } \\
\text { In children coming to term in high flu season the } \\
\text { risk of negative birth outcomes is much higher, } \\
\text { suggesting that exposure to flu late in pregnancy } \\
\text { causes preterm delivery. }\end{array}$ \\
\hline
\end{tabular}

epidemics.

Oizer (2014)

Data on children were collected in

Spillover effects 2009 and in 2010 at all of the

"Conditional on child's age $\&$ data collection Community deworming before age 1:

year, deworming exposure was randomized." Raven's matrices: +0.22 of a SD

of the Kenya

deworming project schools in Samia Treatment group: children born in 1998 in

PPVT: no effect

deworming and Bunyala districts of Kenya's

program

communities $\mathrm{w} /$ the deworming program.

Verbal fluency: $+0.19 \mathrm{SD}$

Western Province; includes $\mathrm{N}=$

measured at 20,000 children with info on

ages 8-15. collected height, weight, and

migration status; and 2,400

community w/out the deworming program "That Raven's Matrices are responsive to the

(the program only started to operate in 2001 intervention suggesting that even mild disease

in control communities, i.e., when these burdens early in childhood can alter cognitive

children, cognitive measures were cohorts were age 3 ).

development."

The seasonal pattern in

health outcomes is observed

across SES, child gender, \& collected.

$$
\text { development." }
$$

1) Danish Birth Records, 1980-1993; Exploit the variation in seasonal influenza in

\section{Schwandt}

(2016). Effect of $\mathrm{N}=700,000$ births.

maternal

for influenza

during

pregnancy on to maternal hospitalizations during

earnings, welfare pregnancy; this dataset helps

dependance, etc. identify influenza-like illness

at $19-32$ in

Denmark.

\section{the month of conception.}

FE.

Author also uses an IV strategy: instrument

for 3rd trimester influenza exposure to

correct for the potential bias that a shorter

duration of pregnancy is correlated with a

shorter period in which a mother can be

infected by influenza. infections in pregnant women.

Datasets are merged using personal

identifiers.
Influenza admission during pregnancy (dummy): BW: -77 grams $(-2.2 \%=-0.14$ SD). LBW: $+2.9 p p$

$(+66 \%)$

Gestation (weeks): $-0.3(-0.8 \%=-0.17 \mathrm{SD})$.

Preterm: $+4 \mathrm{pp}(+88 \%)$

Sex ratio: no effect.

LT outcomes: Earnings: $-10 \%$ (0.09 SD).

Labor force participation: $-7 \%$.

Welfare dependance: $+43 \%$.

Labor mkt outcomes are driven by exposure in 2nd \& 3rd trimesters.
By gender: no differences.

By differential exposure within the $\mathrm{HH}$ :

Having older siblings in an affected school: Raven's matrices $+0.42 \mathrm{SD}$.

Having older female siblings in an affected school:

Raven's matrices +0.84 SD

(females more likely to care for younger siblings).

By mother's educ: Children of mothers $w /$ low educ are less likely to be in school (at ages 18-20) \& have fewer yrs of educ compared to children of other moms. Effects are driven by influenza admissions in the 3rd trimester. 


\begin{tabular}{|c|c|c|c|c|}
\hline Study & Micro - Data, N & Identification strategy and specification & Effects of the shock & $\begin{array}{c}\text { Heterogeneity in } \\
\text { mechanisms/effects }\end{array}$ \\
\hline \multicolumn{5}{|c|}{ el C: Disease } \\
\hline $\begin{array}{l}\text { rataramani } \\
\text { 2). Effects } \\
\text { alaria } \\
\text { sure in } \\
\text { ico on adult } \\
\text { ition. }\end{array}$ & $\begin{array}{l}\text { 1) } 2002 \text { Mexican Family Life Survey; } \\
\mathrm{N}=1,649 \text { men and } 2,184 \text { women. } \\
\text { Data include test scores, } \\
\text { employment, HH \& individual } \\
\text { income, expenditure, education, } \\
\text { anthropmetrics, morbidity, health } \\
\text { care utilization, migration. } \\
\text { 2) State-level data on the avg death } \\
\text { rate (per 100,000) from malaria } \\
\text { 1949-1953 (erradication began in } \\
\text { 1957). }\end{array}$ & $\begin{array}{l}\text { Exploit the nationwide introduction of } \\
\text { malaria eradication efforts in Mexico: } \\
\text { DD Strategy: compare the change in } \\
\text { outcomes btw cohorts born before \& after } \\
\text { the intervention in areas that benefited more } \\
\text { from the policy against the same change for } \\
\text { cohorts born in less malarious regions. } \\
\text { Models include state and year of birth FE } \\
\text { and birth state specific linear time trends, } \\
\text { individual controls. }\end{array}$ & $\begin{array}{l}\text { Birth year exposure to malaria eradication: } \\
\text { Raven Progressive Matrices test } \\
\text { scores: }+0.11 \text { to } 0.22 \text { SD ( }+25 \text { to } 51 \%) \text {. } \\
\text { Household consumption expenditures: }+6.5 \text { to } \\
13.6 \% \text {. } \\
\text { Total Schooling: no effect. } \\
\text { Cohorts affected by the policy entered and exited } \\
\text { school earlier: } \\
\text { Age at school entry: falls by }-0.15 \text { to }-0.37 \text { years. } \\
\text { Age @school exit: falls by }-0.55 \text { to }-1.06 \text { years. }\end{array}$ & $\begin{array}{l}\text { By gender: effects are only } \\
\text { observed for men. }\end{array}$ \\
\hline $\begin{array}{l}d \text { and Phipps } \\
\text { 4). Exposure } \\
4 \text { in utero on } \\
\text { th and } \\
\text { ition of } 4-5 \\
\text { old children } \\
\text { anada. }\end{array}$ & $\begin{array}{l}\text { 1) National Longitudinal Study of } \\
\text { Children and Youth (NLSCY), 1992- } \\
\text { (week 37) to } 2011 \text { (week 34), } \\
\mathrm{N}=11,888 . \\
\text { 2) Rate of laboratory confirmed } \\
\text { influenza includes influenza } \\
\text { laboratory surveillance rates, from } \\
\text { the Canadian Respiratory Virus } \\
\text { Detection/Isolation } \\
\text { Surveillance System (RVDI). } \\
\text { 3) Hospital counts from records of } \\
\text { inpatient discharges, 1996-2006; \& } \\
\text { Google Flu Trends data. }\end{array}$ & $\begin{array}{l}\text { Exploit the weekly variation in Influenza } \\
\text { surveillance rates across provinces to } \\
\text { estimate effects of exposure during gestation } \\
\text { on child cognition \& health. Models include } \\
\text { the Influenza term \& its square to capture } \\
\text { nonlinear effects. Also year, month, \& } \\
\text { province FE, seasonal factors \& individual } \\
\text { characteristics. } \\
\text { Conception date: N of gestational weeks } \\
\text { before e/child's DOB where gestational } \\
\text { length is based on the date of the mother's } \\
\text { last menstrual period. }\end{array}$ & $\begin{array}{l}\text { An increase of } 1 \text { SD from the mean Influenza } \\
\text { surveillance rate (in the whole pregnancy) has no } \\
\text { statistically significant effect. } \\
\text { The effect of each week of Influenza during the } \\
\text { 1st trimester ( } 13 \text { week-period): } \\
\text { PPVT: }-1.1 p p(1.1 \%=0.07 \text { of a SD) } \\
\text { Chronic condition: }-2.8 p p(-14.7 \%=-0.08 \text { of a SD). }\end{array}$ & NA \\
\hline
\end{tabular}




$\begin{array}{cccc}\text { Study } & \text { Micro - Data, N } & \begin{array}{c}\text { Identification strategy and } \\ \text { specification }\end{array} & \begin{array}{c}\text { Effects of the shock } \\ \text { mechanisms/effects }\end{array}\end{array}$

\section{Panel D: Pollution}

Aizer, Currie, 1 1) Blood lead levels (BLL) from Rhode IV to control for confounding and for

Simon, and Vivier Island (RI) Department of Health:

(2016). Examine includes age at test, test method

the effects of (capillary or venous), census tract,

Rhode Island's and BLL.

policies to reduce 2) Child's test scores from the RI

preschool blood Department of Education: include

lead levels on third NECAP12 test scores in 3rd grade.

grade test scores. 3) Confidential birth certificates of

children born in RI: include child's

home address + individual and

maternal characteristics.

$\mathrm{N}=71,000$ children (instrument: introduction of a lead

birth FE.

safe certificates in a neighborhood is

uncorrelated with other factors

increasing test scores.
A 1-unit increase in mean blood lead: measurement error in blood lead levels Reading test score: -0.07 SD (-2\%)

Probability of substantially below proficient in reading: $+25.7 \%$.

Models control for individual covariates,

Census tract FE, average test scores in the The BLL levels declined by 2.23 milligrams

child's school \& grade, year and month of per deciliter from 1997 to 2005.

Key assumption: Growth in the $\mathrm{N}$ of lead

Authors also estimate models using the subset of children who have both venous + capillary measures using the former as instruments for the later.
By score distribution: "The effects are larger at the lower end of the score distribution".

\begin{tabular}{|c|c|}
\hline $\begin{array}{l}\text { Arceo-Gomez, } \\
\text { Hanna, and Oliva } \\
\text { (2012). Asks how } \\
\text { variations in air } \\
\text { pollution (CO and } \\
\text { PM10) due to } \\
\text { inversions in } \\
\text { Mexico City affect } \\
\text { infant mortality. }\end{array}$ & $\begin{array}{l}\text { 1) Mortality data from the Ministry } \\
\text { of Health; includes birth \& death } \\
\text { certificates, \& contains info on date } \\
\text { of birth \& municipality of residen. } \\
\mathrm{N}=\text { not specified. } \\
\text { 2) Pollution: Automatic Network of } \\
\text { Atmospheric Monitoring (RAMA) } \\
\text { longitudinal data; includes PM10, } \\
\text { SO2, CO, O3; years of data 1997- } \\
\text { 2006 for } 48 \text { municipalities. } \\
\text { 3) Thermal inversions data from } \\
\text { Ministry of Environment. }\end{array}$ \\
\hline
\end{tabular}

1) Reduced form model that includes

IV results: $\mathrm{A} 1 \%$ increase in $\mathrm{CO}$ : municipalities FE, week FE, \& municipality- Infant mortality: a $0.23 \%$ increase. specific year trends. 2) IV approach: Exploit the Infant mortality: a $0.42 \%$ increase.

A $1 \%$ increase in PM10 over a year: meteorological phenomenon of thermal 1st stage results: inversions; use the $\mathrm{N}$ of inversions in a $\mathrm{E} /$ inversion leads to a $3.5 \%$ increase in given week to instrument for pollution $\mathrm{PM} 10$ \& a $5.4 \%$ increase in $\mathrm{CO}$. levels that week. IV Models include rich The overall decline in pollution from 1997 controls, municipality \& year FE, \& week- to 2006 predicts a decline of 277 infant municipality trends.

deaths per 100,000 births.
Non-linearities in the effects of

pollution: using estimates from

Currie \& Neidell (2005) authors find suggestive evidence of nonlinearities only in the $\mathrm{CO}$ effect. 


$\begin{array}{cccc}\text { Study } & \text { Micro - Data, N } & \begin{array}{c}\text { Identification strategy and } \\ \text { specification }\end{array} & \begin{array}{c}\text { Effects of the shock } \\ \text { mechanisms/effects }\end{array}\end{array}$

\section{Panel D: Pollution}

Bharadwaj, Gibson, 1) Vital statistics: Universe of births Sibling FE regressions control for child's Graff-Zivin, and $1992-2002 ; \mathrm{N}=627,530$ births.

Nielsen (2016). 2) Education data (SIMCE): test Effect of fetal scores (math, language) for exposure to carbon e/student, 2002-2010. gender, \& for seasonality, temperature, precipitation, fog, wind, \& month and year FE.

monoxide on 4th 3) Data from pollution monitors ( $\mathrm{CO}$, avoidance behavior based on air quality grade test scores in PM10, O3), 1998-2001. Authors alerts.

A 1 SD increase in CO exposure during the By mother's educ:

3rd trimester of pregnancy: effects of $\mathrm{CO}$ exposure are larger for 4th grade math test scores: $-0.036 \mathrm{SD}$. children of mothers w/out a high 4 th grade language test scores: -0.042 SD. school diploma.

No significant effects were observed in 1st Language test scores: -0.096 SD in Chile. construct an Air Quality Index (AQI) 4) Data on air quality alerts to help address concerns related to

As a robustness check, authors use PM1 or 2nd trim. Sibling FE slightly larger than OLS 1 st trim \& -0.082 SD in 3rd trim whereas for children more educ instead of $\mathrm{CO} \&$ include ozone pollution avoidance behavior. level controls. mothers effect is 0.029 sdin 3 rd Controlling for avoidance behavior, has a trimester. Data are merged using individual ids.

\section{Billings and \\ 1) Admin data from the "Lead}

Schnepel (2015). Poisoning Prevention Program" in

Effects of an Early Charlotte NC, includes preschool

Intervention for blood lead level tests.

Children Exposed

to Lead. 2) Public school records: k-garten to individuals in treatment group (2 tests 12th grade, $1998-1999$ to $2010-2011$. with $B L L>=10 \mu \mathrm{g} / \mathrm{dL}$ ) with control group 3) Criminal arrest records 2006-2013. (1st test with BLL $>=10 \mu \mathrm{g} / \mathrm{dL} \&$ 2nd test of 4) Birth certificate records from NC: $5 \mu \mathrm{g} / \mathrm{dL}<=\mathrm{BLL}<=10 \mu \mathrm{g} / \mathrm{dL}$ ). 1990-1997, provides parental info \& "Basic intervention": education for child's BW.

5) County assessor's data for all parcels; match to lead test results based on home address. $\mathrm{N}=312$ children (treatment 119 ; control 193).

Authors match $54 \%$ to $86 \%$ of data. evaluation + WIC

\section{Children with 2 consecutive tests of 10} micrograms of lead per deciliter of blood to:

$(\mu \mathrm{g} / \mathrm{dL})$ receive an elevated Blood lead level (BLL) intervention. DD: Compare

\section{Children with high BLL who were assigned NA}

Basic intervention: Antisocial behavior (Index based on absences \& $\mathrm{N}$ of days suspended, school reported crimes,

adolescent

criminal arrests, positive effect is good):

+0.179 SD.

Education (Index based on math \& reading caregivers, optional home investigation, test, grade retention): +0.128 SD. referral to lead remediation services Intensive intervention: Antisocial behavior: "Intensive intervention": services in basic +0.382 SD. Education: +0.368 SD. + nutritional assessment + medical 


$\begin{array}{cccc}\text { Study } & \text { Micro - Data, N } & \begin{array}{c}\text { Identification strategy and } \\ \text { specification }\end{array} & \begin{array}{c}\text { Effects of the shock } \\ \text { mechanisms/effects }\end{array}\end{array}$

\section{Panel D: Pollution}

Black, Bütikofer, 1) Norwegian registry data covers the Regional fallout was determined by wind, A 1 SD increase in monthly exposure to Devereux, and population of Norwegians up to 2009 rainfall, \& topography. Significant fallout ground(air) radiation:

Little evidence for non-linearities

Salvanes (2014). ～(education register, family register, in 1957-1958 \& in $1962-1963$.

Male IQ scores: -0.04 (-0.06) of a SD (effect increasing in magnitude w/quintile);

Ask how prenatal tax and earnings register); $\mathrm{N}=37,000$. Authors compare individuals born within size: $-2 \%(-1 \%)$ of a SD) (exposure in $\quad$ only for quintiles $3-5$ of exposure

exposure to fallout 2) Norwegian military records,

from above ground provides IQ scores for men only; nuclear testing in $\mathrm{N}=94,649$.

the 1950s and $\quad 3$ ) Norwegian Defense Research

1960s affected IQ, Establishment: Total beta radiation

earnings, in the air expressed as $\mathrm{Bq} / \mathrm{m3}$, and

education at 18-35 (ii) total beta radiation on the

years in Norway. ground) expressed in $\mathrm{Bq} / \mathrm{m} 2$.

the same municipality but born in diff. months $3 \& 4)$.

that there are any significant

month/year of birth (and thus exposed to Yrs of schooling: -0.08 (-1\%) (men), -0.1 (- negative impacts of radioactive different levels of radiation in utero). $\quad 1 \%$ ) (women) (exposure in months $3 \& 4$ ). fallout.

Models include individual/family Earnings and adult height: negative

charact, municipality of birth FE \& YOB* although weak effects.

month of birth FE's, municipality linear

trends, interactions between municp*yr,

Intergenerational transmission of HK:

Effects are greater for individuals

\& munip*month sibling FE.

born to more highly educated

parents.

Exposure of parents in utero

leads to Son's IQ: -0.025 of a SD (no effect

for daughters).

\begin{tabular}{|c|c|c|}
\hline Currie (2011). & 1) Individual-Level & DD model: Exploit timing in exposure to \\
\hline Asks whether & Natality Data, 5 large states (FL, MI, & the pollution cleanups $\&$ the distance of \\
\hline minority and less & NJ, PA, \& TX), 1989 (N= 3,948,042 & mother's residence to pollution sites. \\
\hline educated mothers & singleton births) \& 2006 & The treatment is "Close $\times$ (After \\
\hline $\begin{array}{l}\text { are more likely to } \\
\text { be exposed to } \\
\text { toxic releases from } \\
\text { plants and/or }\end{array}$ & $\begin{array}{l}\text { ( } N=4,121,898) \text {; data include a } \\
\text { mother's residential location. } \\
\text { 2) Data on pollution: Superfund sites } \\
\text { (see column J) \& facilities listed in the }\end{array}$ & $\begin{array}{l}\text { Cleanup)" which represents the extent to } \\
\text { which the area surrounding a Superfund } \\
\text { site became "Y" (e.g., "whiter") after a } \\
\text { cleanup. }\end{array}$ \\
\hline $\begin{array}{l}\text { Superfund sites } \\
\text { during pregnancy }\end{array}$ & EPA TRI. & $\begin{array}{l}\text { Models include rich mother controls \& } \\
\text { controls for county \& yr of child's birth FE }\end{array}$ \\
\hline $\begin{array}{l}\text { in } 5 \text { large U.S. } \\
\text { states. }\end{array}$ & & $\begin{array}{l}\text { Also examine effects of information } \\
\text { about toxic release inventory sites on } \\
\text { migration. }\end{array}$ \\
\hline
\end{tabular}

Following cleanups, mothers in the

Whites and educated mothers are

immediate vicinity of a Superfund site are more likely to respond to

more likely to be: "white college educated" information or changes in pollution mothers: $+10.1 \%$.

levels, which may partially explain

Also, white college educated mothers are lower exposure levels.

more likely to leave an area when new

information about toxic releases is

revealed $-8.7 \%$.

migration. 


$\begin{array}{cccc}\text { Study } & \text { Micro - Data, } \mathbf{N} & \begin{array}{c}\text { Identification strategy and } \\ \text { specification }\end{array} & \begin{array}{c}\text { Effects of the shock } \\ \text { mechanisms/effects }\end{array}\end{array}$

\section{Panel D: Pollution}

Currie, Graff Zivin, 1) NJ vital statistics natality data - all Sibling FE with IV (instrument for actual Meckel, et al. births, 1997-2007, include mother's contamination using the contamination (2013). Asks how residence, siblings matched using that would have been experienced had potential exposure mother's full maiden name, race \& gestation lasted exactly 39 weeks). to contaminated birth date, father's information, \& Models control for temperature \& other drinking water SSN; $\mathrm{N}=521,978$.

affects birth $\quad 2$ ) Records of drinking water

outcomes in New violations in NJ, 1997-2007.

Jersey. $\quad$ 3) Temperature \& precipitation statistics.

4) Map of drinking water service areas in New Jersey.

Living in a water district with contaminated LBW: + 14.6\% (of a SD) for mothers water during pregnancy: $\quad$ with HS educ or less; using mother-FE + IV: $\quad$ Prob(preterm birth): $+10.3 \%$ (of a LBW: $+6 \%$ due to any chemical cont. $+14 \%$ SD) for mothers with HS educ or controls, \& year*month of birth effects. Prob(preterm): no effects (full sample). Authors address the mechanical Authors address the mechanical correlation btw gestation length, and correlation btw gestation length \& exposures by using IV. due to any contamination. less.

exposures by using IV.

\begin{tabular}{|c|c|c|c|}
\hline $\begin{array}{l}\text { Currie and Walker } \\
\text { (2011). Estimate }\end{array}$ & $\begin{array}{l}\text { 1) Vital Statistics Natality records } \\
\text { from PA, 1997-2002. }\end{array}$ & $\begin{array}{l}\text { Exploit the introduction of electronic toll } \\
\text { collection (E-ZPass). }\end{array}$ & $\begin{array}{l}\text { E-ZPass adoption reduced NO2 by } 10.8 \% \text {, } \\
\text { likely reduced CO by } 40 \% \text { near toll plazas. }\end{array}$ \\
\hline effects of E-ZPass & 2) Vital Statistics Natality records & Diff-in-Diff: compare mothers within $2 \mathrm{~km}$ & E-ZPass adoption (comparing children of \\
\hline (which reduced & from NJ, 1994-2003. & of a toll plaza to mothers who are 2 to 10 & mothers within $2 \mathrm{~km}$ of a toll plaza to \\
\hline $\begin{array}{l}\text { traffic congestion } \\
\text { and vehicle }\end{array}$ & $\begin{array}{l}\text { 3) Data on housing prices in NJ, 1989- } \\
2009 \text { to test if housing prices. }\end{array}$ & $\mathrm{km}$ from a toll plaza. & $\begin{array}{l}\text { those of mothers who are } 2 \text { to } 10 \mathrm{~km} \text { from } \\
\text { a toll plaza): }\end{array}$ \\
\hline emissions near & $\mathrm{N}=412,884$ observations. & Models include month and year of birth & Prematurity: $-9.0 \%$; LBW: $-11.3 \%$. \\
\hline $\begin{array}{l}\text { highway toll } \\
\text { plazas) on birth }\end{array}$ & $\begin{array}{l}\text { Authors know the exact addresses of } \\
\text { mothers. }\end{array}$ & $\begin{array}{l}\mathrm{FE} \text {, toll plaza } \mathrm{FE} \text {, distance to highway, and } \\
\text { maternal characteristics. }\end{array}$ & $\begin{array}{l}\text { A } 1-4 \% \text { decline in pollution from cars leads } \\
\text { to a } 1 \% \text { decline in LBW. }\end{array}$ \\
\hline
\end{tabular}

plazas) mothers. maternal characteristics.

to a $1 \%$ decline in LBW.

\begin{tabular}{|c|c|c|c|c|}
\hline $\begin{array}{l}\text { Ferrie, Rolf, and } \\
\text { Troesken (2014). } \\
\text { Asks how lead in } \\
\text { the water supply in } \\
\text { the early 20th } \\
\text { century affected } \\
\text { the intelligence of } \\
\text { Army Air Corps } \\
\text { members in WWII. }\end{array}$ & $\begin{array}{l}\text { 1) } 5 \% \text { sample of the } 1930 \text { U.S. Pop } \\
\text { Census. } \\
\text { 2) Data on assignment to the air } \\
\text { corps among Army recruits during } \\
\text { WWII. } \\
\mathrm{N}=44,040 \text { enlistees in } 293 \text { cities. } \\
\text { 3) Data on pH level of water used by } \\
\text { the public water company in the } \\
\text { enlistee's city of residence \& w/the } \\
\text { enlistee's air corps status. }\end{array}$ & $\begin{array}{l}\text { Authors use "enlistee's state of birth" to } \\
\text { identify early-exposure to lead. Water } \\
\text { with high ph creates scale in lead pipes } \\
\text { which reduces lead in water. } \\
\text { Models include year \& state of birth FE, a } \\
\text { dummy for SES and an interaction btw } \\
\text { SES and both pH and pH-squared. }\end{array}$ & $\begin{array}{l}\text { Intelligence (dummy for assignment to the } \\
\text { Army Air Corps): } \\
\text { The probability of assignment to air corps } \\
\text { was significantly reduced when water pH } \\
\text { decreased (below 7.5) or increased (above } \\
\text { 7.5), and this U-shape relationship was } \\
\text { particularly strong for enlistees from low } \\
\text { SES backgrounds. }\end{array}$ & $\begin{array}{l}\text { Living in a city with acidic water } \\
\text { increases the probability that a } \\
\text { recruit from a blue collar family was } \\
\text { assigned to the air corps by } 7 \% \text {. No } \\
\text { effect for recruits from white collar } \\
\text { families. } \\
\text { Similar contrasts observed } \\
\text { comparing children from } \\
\text { unemployed vs. employed fathers } \\
\text { and in HH's with low rent vs. high } \\
\text { rent. }\end{array}$ \\
\hline
\end{tabular}

\section{African Americans only:} Prematurity: $-22.4 \%$ LBW: $-29.5 \%$

outcomes. 


\begin{tabular}{|c|c|c|c|c|}
\hline Study & Micro - Data, N & $\begin{array}{l}\text { Identification strategy and } \\
\text { specification }\end{array}$ & Effects of the shock & $\begin{array}{c}\text { Heterogeneity in } \\
\text { mechanisms/effects }\end{array}$ \\
\hline \multicolumn{5}{|c|}{ Panel D: Pollution } \\
\hline $\begin{array}{l}\text { Isen, Rossin-Slater, } \\
\text { and Walker (2016). } \\
\text { Effects of } \\
\text { reductions in air } \\
\text { pollution in non- } \\
\text { attainment } \\
\text { counties due to } \\
\text { the } 1970 \text { Clean Air } \\
\text { Acts on } \\
\text { employment and } \\
\text { earnings at ages } 29 \text { - } \\
31 .\end{array}$ & $\begin{array}{l}\text { Longitudinal Employer Household } \\
\text { Dynamics (LEHD); } 1998-2007 \text {, } \\
\text { includes location \& DOB. N=5.7M } \\
\text { indiv.; universe of employed } \\
\text { workforce quarterly earnings } \\
\text { records; authors collapse data to the } \\
\text { county*year ( } 888 \text { units in total). } \\
\text { Earnings records: Ul-covered } \\
\text { earnings by employer/ quarter. } \\
\text { Algorithm to match county of birth in } \\
\text { - LEHD to GNIS ( } 95 \% \text { of indiv. } \\
\text { matched). } \\
\text { 2) Authors match data to the REIS for } \\
\text { county characteristics. } \\
\text { 3) Authors match data to NCHS to } \\
\text { examine infant health \& use } \\
\text { maternal, paternal, child } \\
\text { characteristics. }\end{array}$ & $\begin{array}{l}\text { Exploit sharp changes in ambient air } \\
\text { pollution due to the implementation of } \\
\text { the } 1970 \text { Clean Air Act Amendments } \\
\text { (CAAA) to investigate effects of cleaner } \\
\text { air on adult earnings. } \\
\text { Compare cohorts born just before \& just } \\
\text { after the CAAA. Three methods: } \\
\text { 1) reduced form model of the LT effect of } \\
\text { TSP on earnings; these models include } \\
\text { county FE, birth- } \\
\text { state*year FE, indiv. controls. } \\
\text { 2) two-step estimator: to construct group- } \\
\text { level adjusted earnings (p. 9). } \\
\text { 3) IV for air quality in county at birth. IV: } \\
\text { dummy for the } 1970 \text { CAAA introduction } \\
\text { at the county-year level. }\end{array}$ & $\begin{array}{l}\text { A } 10 \text { unit decrease in TSP in-utero: } \\
\text { Quarters employed: }+0.7 \% \\
\text { Annual earnings: }+1 \% \\
\text { Gains in lifetime income: }+\$ 4,300 \text { (using a } \\
5 \% \text { annual discount rate) ( } 2008 \text { dollars). } \\
\text { Total wage bill attributable to improved } \\
\text { early life air quality: } \$ 6.5 \text { Bill. /cohort (2008 } \\
\text { dollars). } \\
\text { 1st stage: } \\
\text { CAAA reduced TSP concentrations by } 8-12 \\
\text { g/m3 (10\% reduction; mean } 95.9 \mathrm{~g} / \mathrm{m} 3) . \\
\end{array}$ & $\begin{array}{l}\text { By percentiles of the earnings } \\
\text { distribution: most of the mean } \\
\text { earnings effect is being driven by } \\
\text { the bottom tail of the distribution } \\
\text { (CAAA is associated with a decrease } \\
\text { in the fraction of indiv. at the } \\
\text { bottom tail of the distrib. \& an } \\
\text { increase in the fractions in middle } \\
\text { parts of the distribution). } \\
\text { Authors find little heterogeneity in } \\
\text { effects of TSP on labor market } \\
\text { outcomes across age groups (age } \\
28,29,30, \& 31 \text { ). } \\
\text { Little heterogeneity across gender, } \\
\text { race (results not shown). }\end{array}$ \\
\hline $\begin{array}{l}\text { Knittel, Miller, and } \\
\text { Sanders (2011). } \\
\text { Ask how zip code } \\
\text { level variations in } \\
\text { air pollution due to } \\
\text { traffic patterns } \\
\text { affect infant health } \\
\text { outcomes in } \\
\text { California. }\end{array}$ & $\begin{array}{l}\text { 1) Vital statistics, 2002-2007, birth \& } \\
\text { death records. } \\
\text { 2) Freeway Performance } \\
\text { Measurement System (PeMS); traffic } \\
\text { measures from freeways in } \\
\text { Sacramento Valley, the Bay Area, \& } \\
\text { Los Angeles Basin. } \\
\text { 3) EPA data on ambient pollution } \\
\text { levels. } \\
\text { 4) National Climatic Data Center info } \\
\text { on ambient weather conditions. } \\
\text { Authors collapse the data into } \\
\text { mother zip code by birth week by } \\
\text { total weeks survived cells; } \mathrm{N}= \\
\text { 1,436,739 obs. }\end{array}$ & $\begin{array}{l}\text { Exploit the relationship between traffic } \\
\text { fluctuations, ambient weather conditions, } \\
\text { \& various pollutants (CO, PM10 } \\
\text { micrometers, \& ground-level ozone) at } \\
\text { the week \& zip-code levels in CA. } \\
\text { Instrument for week-to-week pollution } \\
\text { using zip-level traffic \& zip-level traffic } \\
\text { interacted w/linear \& quadratic weather } \\
\text { variables). } \\
\text { Models include rich weather and } \\
\text { individual-level controls, a flexible spline } \\
\text { in age in weeks, zip_code FE, } \\
\text { zip*month*year FE. }\end{array}$ & $\begin{array}{l}\text { A one-unit decrease in PM10: } \\
\text { Infant mortality: -18 lives per 100,000 live } \\
\text { births (-6\%). } \\
\text { Neither CO nor ozone have a statistically } \\
\text { significant impact on child mortality. } \\
\text { 1st stage: local pollution instrumented by } \\
\text { car traffic \& the interaction btw car traffic } \\
\text { \& weather measures is strong; however, } \\
\text { authors do not show results on 1st stage. }\end{array}$ & $\begin{array}{l}\text { A one-unit decrease in PM10: } \\
\text { Blacks: no effect (but perhaps few } \\
\text { blacks in CA). } \\
\text { Births covered by Medicaid: }-23 \\
\text { lives per } 100,000 \text { live births ( } \sim-8 \%) \text {. } \\
\text { Births to HS dropouts: }-29 \text { lives per } \\
100,000 \text { live births ( }-10 \%) .\end{array}$ \\
\hline
\end{tabular}


Table 1: Effects of Mild Early Life Shocks on Future Outcomes

Identification strategy and

Effects of the shock

Heterogeneity in

specification

mechanisms/effects

Panel D: Pollution

Sanders (2012). 1) Texas Education Agency (TEA)

Asks how variation includes data on the Texas

pollution in the

Counties with more manufacturing saw greater decreases in pollution in the

A 1SD decrease in TSP in a student's year of birth:

county and year of \& on the Texas Learning Index (TLI), Instrument pollution levels using county

birth affects 10th 1994-2002, 10th graders; $\mathrm{N}=$

grade math test $1,902,463$ studentsin 416 schools

scores in Texas. across 30 countie.

2) EPA database of historical air

quality; includes readings

employment.

Instrument=TSPs as a function of all

workers in a county employed

in the manufacturing industry (SIC code

$\begin{array}{lll} & \end{array} 00$ )/total county employment levels in

miles of a county population

centroid.

all other sectors in a given year.

Estimates are LATE. Models include rich

3) Global Surface Summary of the

day: weather data.

REIS data on county

characteristics. $\mu \mathrm{g} / \mathrm{m} 3$ (F-test $\sim 33$ ).

IV estimates are larger than OLS estimates ( 0.06 vesus 0.02 of a SD) which could be

due to: measurement error $\&$ the fact that IV identify local effects. controls, school FE, year of test FE,

school*year pupil-to-teacher ratios from

the CCD. Data is collapsed by

demographic group, school of

attendance, year of birth, and year of

test; regressions are weighted.
High school test scores: 0.06 of a SD

Results are significant only in the

periods of the most drastic

pollution variation, suggesting a

subtle relationship that may be

difficult to separate from

relative manufacturing employment

background trends. 


\begin{tabular}{llll}
\hline \multicolumn{1}{c}{ Study } & \multicolumn{1}{c}{ Micro - Data, $\mathbf{N}$} & \multicolumn{1}{c}{$\begin{array}{c}\text { Identification strategy and } \\
\text { specification }\end{array}$} & \multicolumn{1}{c}{ Effects of the shock } \\
mechanisms/effects
\end{tabular}

\begin{tabular}{|c|c|c|c|c|}
\hline $\begin{array}{l}\text { Krutikova and } \\
\text { Lilleor (2015). } \\
\text { Variations in } \\
\text { rainfall in rural } \\
\text { Tanzania in } 10 \\
\text { years around } \\
\text { birth on } \\
\text { outcomes at } 17 \\
\text { to } 28 \text {. }\end{array}$ & $\begin{array}{l}\text { 1) the Kagera Health and Development } \\
\text { Survey (KHDS); Baseline 1991-1994 ( } 915 \\
\text { households in } 51 \text { villages), 1st follow-up } \\
\text { in } 2004 \text { (sample expanded to } 2500 \mathrm{HHs} \text { ); } \\
\text { 2nd follow-up in } 2010 \text { (sample expanded } \\
\text { to } 3300 \mathrm{HHs).} \mathrm{The} \mathrm{last} \mathrm{waves} \mathrm{include} \mathrm{the} \\
\text { outcome of interest. Final sample } \mathrm{N}=897 \\
\text { individuals. } \\
\text { 2) Rainfall data at the monthly - village } \\
\text { level. }\end{array}$ & $\begin{array}{l}\text { Exploit the geographic and temporal } \\
\text { variation in rainfall across villages in rural } \\
\text { Tanzania. } \\
\text { Siblings FE models. The coefficient of } \\
\text { interest is the effect of rainfall in utero, in } 0 \text { - } \\
1,1-2 \text { years of life. }\end{array}$ & $\begin{array}{l}\text { A } 10 \% \text { increase in rainfall from the LR } \\
\text { avg: } \\
\text { "Core self-evaluation" (relative to } \\
\text { siblings): }+0.08 \text { SD. (Note: no descriptive } \\
\text { table with outcomes to convert the } \\
\text { coefficient). } \\
\text { Effect is significant ONLY in utero and not } \\
\text { in the first } 2 \text { years of life. } \\
\text { By trimester: the effect is similar across } \\
\text { all trimesters (beta } 0.08 \text { SD). }\end{array}$ & $\begin{array}{l}\text { By gender: little difference in } \\
\text { the effects of rainfall. }\end{array}$ \\
\hline
\end{tabular}




\begin{tabular}{|c|c|c|c|c|}
\hline Study & Micro - Data, N & $\begin{array}{l}\text { Identification strategy and } \\
\text { specification }\end{array}$ & Effects of the shock & $\begin{array}{c}\text { Heterogeneity in } \\
\text { mechanisms/effects }\end{array}$ \\
\hline \multicolumn{5}{|c|}{ Panel E: Weather } \\
\hline $\begin{array}{l}\text { Rocha and } \\
\text { Soares (2014). } \\
\text { Rainfall } \\
\text { fluctuations in } \\
\text { semi-arid parts } \\
\text { of Brazil during } \\
\text { gestational } \\
\text { period and } \\
\text { effects on birth } \\
\text { weight and } \\
\text { infant mortality. }\end{array}$ & $\begin{array}{l}\text { 1) Birth and mortality registration } \\
\text { records used to create a municipality-by- } \\
\text { month panel, } 1996 \text {-2010; N=188,640 } \\
\text { obs. } \\
\text { 2) Precipitation \& temperature } \\
\text { municipality-by-month weather data. } \\
\text { 3) Census of } 2000 \text { \& 2010: provides } \\
\text { municipality info on the } \% \text { of households } \\
\text { w/access to piped water, sanitation. }\end{array}$ & $\begin{array}{l}\text { Exploit variation in rainfall at the } \\
\text { municipality \& monthly levels. } \\
\text { Health outcomes (measured as the } \\
\text { municipality avg for children born in } \\
\text { municipality i, on year } y \text {, month } \mathrm{t} \text { ) are } \\
\text { regressed on avgerage temperature in the } \\
\text { municipality over last } 12 \text {-months, } \\
\text { municipality-by-month of birth FE, year of } \\
\text { birth FE, \& municipality-level trends. }\end{array}$ & $\begin{array}{l}\text { A } 1 \text { SD increase in rainfall: } \\
\text { Infant mortality: }-5 \% \text { w.r.t. the sample } \\
\text { avg of } 30 \text { deaths } / 1000 \text { births. } \\
\text { BW: }+1.6 \text { grams ( }+0.05 \%=+0.03 \mathrm{SD}) \text {. } \\
\text { Fraction of full-term pregnancies: }+0.3 p p \\
(+0.32 \%=+0.027 \mathrm{SD}) \text {. } \\
\text { Effects are stronger during the } 2 \mathrm{nd} \\
\text { trimester of gestation, for children born } \\
\text { during the dry season, \& for mortality } \\
\text { immediately after birth. } \\
\text { Potential benefits from expanding the } \\
\text { piped water \& sanitation systems exceed } \\
\text { the cost. }\end{array}$ & $\begin{array}{l}\text { By child's gender: slightly } \\
\text { higher effects for girls, } \\
\text { particularly for intestinal } \\
\text { infections, malnutrition, \& } \\
\text { perinatal conditions; BW } \\
\text { effects are larger for girls than } \\
\text { for boys, while the coefficients } \\
\text { for length of gestation are } \\
\text { almost identical across } \\
\text { genders. }\end{array}$ \\
\hline
\end{tabular}

\begin{tabular}{|c|c|c|c|c|}
\hline $\begin{array}{l}\text { Rosales (2015). } \\
\text { Effects of } \\
\text { exposure to El } \\
\text { Nino floods in } \\
\text { utero and during } \\
\text { 1st year on birth } \\
\text { weight, height, } \\
\text { and test scores. }\end{array}$ & $\begin{array}{l}\text { 1) Longitudinal HH survey on Ecuador's } \\
\text { cash transfer program "Bono de } \\
\text { Desarrollo Humano." } \\
\text { 1st wave: 2003-2004; 2nd wave: 2005- } \\
\text { 2006; N 8,000 children. Sample over- } \\
\text { represents poor families. } \\
\text { 2) Reproductive and Health Survey (RHS): } \\
\text { 1994, 1999. } \\
\text { 3) Living Standards Measurement Survey } \\
\text { (LSMS): } 1995,1998,1999 \text {. Last two are } \\
\text { nationally representative. }\end{array}$ & $\begin{array}{l}\text { DD model: } \\
\text { Compare regions that experienced El Nino } \\
\text { vs. those that did not and during the years of } \\
\text { El Nino 1998/1999 versus previous years. } \\
\text { Model includes individual controls, village of } \\
\text { residence FE, year of child's birth FE. }\end{array}$ & $\begin{array}{l}\text { Exposure to El Nino floods (avg exp } 3 \\
\text { mths): } \\
\text { HAZ }=-0.09 \text { of } 1 \text { SD (effects 3rd trim); } \\
\text { PPVT }=-0.13 \text { of } 1 S D \text { (effects } 1 \text { st trim) } \\
\text { LBW }=+2.3 p p \text { (3rd trim) }(14.6 \%=0.06 \text { of } \\
\text { a SD). }\end{array}$ & $\begin{array}{l}\text { 1) By maternal educ: effects on } \\
\text { PPVT are smaller for children } \\
\text { w/more educated mothers } \\
\text { (effects: - } 0.02 \text { SD). } \\
\text { 2) By rural/urban: effects on } \\
\text { PPVT are stronger for rural } \\
\text { children (effects: }-0.01 \text { SD). } \\
\text { 3) By SES index (1-2 quintiles } \\
\text { vs. 4-5): effects on LBW } \\
\text { significant for children in low } \\
\text { quintiles (effects: }+3.2 p p) \text {. }\end{array}$ \\
\hline
\end{tabular}




\begin{tabular}{|c|c|c|c|c|}
\hline Study & Micro - Data, N & $\begin{array}{l}\text { Identification strategy and } \\
\text { specification }\end{array}$ & Effects of the shock & $\begin{array}{c}\text { Heterogeneity in } \\
\text { mechanisms/effects }\end{array}$ \\
\hline \multicolumn{5}{|c|}{ Panel E: Weather } \\
\hline $\begin{array}{l}\text { Shah and Millett } \\
\text { Steinberg (2016). } \\
\text { Rainfall shocks in } \\
\text { rural India in } \\
\text { utero and } \\
\text { current on } \\
\text { outcomes for } \\
\text { children and } \\
\text { young adults. }\end{array}$ & $\begin{array}{l}\text { 1) Survey on educational achievement of } \\
\text { primary school children in rural India } \\
\text { conducted every year over } 5 \text { years from } \\
2005-2009 ; \mathrm{N}=2 \text { million children. } \\
\text { 2) Monthly district rainfall data. } \\
\text { 3) NSS (National Sample Survey) } \\
\text { collected by the Government of India's in } \\
2004-2008 \text {; includes information on } \\
\text { wages, labor, etc. }\end{array}$ & $\begin{array}{l}\text { Rainfall varition: within district \& across } \\
\text { districts within a year. Authors explore } \\
\text { different periods of exposure: i) current } \\
\text { shocks; ii) exposure in utero up to age } 4 \text {; iii) } \\
\text { exposure in utero up to age } 16 \text {. } \\
\text { Sibling FE models also include district FE, age } \\
\text { FE, year of survey FE. }\end{array}$ & 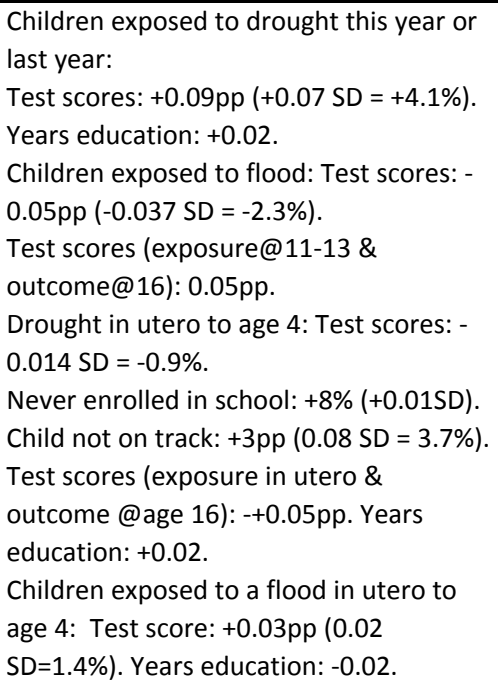 & $\begin{array}{l}\text { By mother's education: effects } \\
\text { are exclusively concentrated } \\
\text { among children whose } \\
\text { mother's had no schooling. } \\
\text { By districts w/more } \\
\text { educational expenditure: } \\
\text { Investments in educ help } \\
\text { mitigate the negative effect of } \\
\text { rainfall on test scores. }\end{array}$ \\
\hline $\begin{array}{l}\text { Wernerfelt, } \\
\text { Slusky, and } \\
\text { Zeckhauser } \\
\text { (2016). Effects } \\
\text { of in utero } \\
\text { exposure to } \\
\text { sunlight (vitamin } \\
\text { D) on childhood } \\
\text { asthma up to } \\
\text { age } 10 .\end{array}$ & $\begin{array}{l}\text { Two independent datasets: } \\
\text { 1) NHIS: private individual-level data, } \\
\text { aggregated by state, month, \& year of } \\
\text { birth, 1914-1987, N=260,000. } \\
\text { NHIS data merged w/ historical weather } \\
\text { data from the NOAA. } \\
\text { 2) Asthma hospital discharge data from } \\
\text { NJ \& AZ, from the Health Care Utilization } \\
\text { Project and birth records from Vital } \\
\text { Statistics; data aggreggated at the } \\
\text { county, birth month, \& year of birth, } \\
\text { 1999-2009; N=2.1 million births ( } 3,000 \\
\text { birth month by county cohorts). }\end{array}$ & $\begin{array}{l}\text { Exploit the exogenous } \\
\text { within-location variation in sunlight levels } \\
\text { across birth years in location of birth. } \\
\text { Assumes sunlight variation correlates } \\
\text { w/actual exposure, but not w/ other factors } \\
\text { affecting asthma incidence. Regressions } \\
\text { include state of birth * month of birth FE, } \\
\text { year of birth FE. }\end{array}$ & $\begin{array}{l}\text { Doubling the amount of sunshine in an } \\
\text { individual's location during the } 2 \text { nd trim: } \\
\text { Dataset 1) } \\
\text { Prob(report asthma diagnosed): }-1.15 p p \\
\text { (-10\%) (no standard deviations provided). } \\
\text { Dataset 2) } \\
\text { Rate of asthma emergency department } \\
\text { discharges: -2.21pp (-21.3\%) (no } \\
\text { standard deviations provided). } \\
\text { No effects in 1st or 3rd trimester in } \\
\text { either data set. }\end{array}$ & NA \\
\hline
\end{tabular}




\section{Panel F: Alcohol and Tobacco Policy}

\section{$\begin{array}{ll}\text { Barreca and Page 1) Birth outcomes from the National } & \end{array}$} (2015). Focus on Center for Health Statistics (NCHS) effects of changes in natality

minimum legal files (1968-1989), $N=73,973$.

drinking age in state 2) Month-year MDLA data from

and year of birth, Distilled Spirits Council of the U.S.

1978-1988. Datasets matched by mother's

estimated age at conception, month of

conception, \& mother's state of

residence at delivery.

Bharadwaj,

1) Birth records for all Norwegian

ohnsen, and Løken births, 1967 to 2010 , includes unique

(2014). Effects of a identifiers, \& smoking behavior at the

smoking ban in start and end of pregnancy.

in Norway on health 1967-2010 (includes gender, DOB, city,

at birth. marital status, years of education, LFP,

earnings, occupation)

$\mathrm{N}=4,030$

\section{Nilsson (2015). 1) LOUISE database covering all}

The effect of alcohol individuals of ages 16 to 65 , living or

consumption during working in Sweden 1990- 2004;

pregnancy on long- includes year \& month of birth, gend

term outcomes of \& region of $\&$ ith, education, labor

generation. Individuals linked to biological parents Individuals linked to biological parents $\mathrm{N}=4,104$ obs. $\mathrm{N}=4,104$ obs.

2) Military enlistment data on cognitive \& non-cognitive outcomes for 18 year old males.

\section{Simon (2016). \\ 1) NHIS - restricted-use geocoded data}

Changes in maternal $1997-2010 ; \mathrm{N}=118,271$

smoking due to tax 2) Vital statistics, 1989-2004,

changes and health $\mathrm{N}^{\sim 2}$ million.

of U.S. 3-17 year

olds.
DDD approach: exploiting variation in MLDA laws that occurred across states in 1970s-1980s. Comparing birth outcomes btw: Treatment: infants of

ther's 14-20 years old and Control group: infants born to mothers 21-24 LBW: $-0.10 \mathrm{pp}(-1.2 \%)$ (Table 1 does not include SD!)

years old.

Models include state of birth, month, \& yearof birth FE, \& age-by-year FE \& No effects on Apgar, preterm birth, congential defects. state-by-age FE.
Whites:

LBW: small increase

Sex ratio: no effects

Blacks' fetuses are pos

Preterm: $-0.3 p p$

Sex ratio: $+0.462 \mathrm{pp}$

\section{Exploit a smoking ban in Norway as a natural experiment. Authors are able to} identify mothers who worked in restaurants \& bars during the period of interest. DD: by compares outcomes before $\&$ after the law change for people working in restaurants \& bars to the same difference among peop who work in a similar occupations. Also estimate twin FE models.

for

for gestational age $=-26 \%=-0.04 \mathrm{SD})$.
Pre-term: $-2.5 \mathrm{pp}(-39 \%=-0.10$ of a SD)
Twin FE: children born after the reform

BW: distribution. A 100 sion). VLBW: -5.8pp.

conditional on full time employment by $0.7 \%$.
Effects of the reform: stronger for $N$ mothers who reported smoking at start of pregnancy.

$\mathrm{BW}:+160 \mathrm{gr}$ (mothers who smoked at the start of preg; effect is concentrated at the lower tails of the BW

distribution); no effect on non-smoking mothers.

\section{Exploit an alcohol policy in Sweeden in the late 1960s that temporarily and Children born to mothers under the age of 21 at delivery, in the} sharply increased access to strong beer in certain regions and among young treatment regions, and conceived between July and October 1967: people. DDD: compare the cohort that was exposed to the policy change in- Earnings: $-24 \%$

utero to cohorts exposed at other moments in their life exploiting variation Prob(no earnings): $+56 \%(+7.2 \mathrm{pp})$

in: i) year and month-of-birth, ii) region of birth, iii) age of the mother (below/ Prob(welfare recipient): $+56 \%(+3.5 \mathrm{pp})$.

above age 21). Models include mother FE.

Prob(low cognitive ability): $+27 \%$.

Prob(low non-cognitive ability): $+16 \%$

Years of schooling: $-0.3(-2.6 \%)$

Effects on the next generation:

Health at birth outcomes: no effects on prematurely born, LBW, sex ratio.

Effects of the policy: Earnings: - $24 \%$ (men only).

Prob(no earnings): $+74 \%(+8.3 \mathrm{pp})$ (men only).

Prob(welfare recipient): $+79 \%(+4.5 \mathrm{pp})$ (men); $+40 \%(+2.7 \mathrm{pp})$ (women).

Years of schooling: $-0.5(-4.3 \%)($ men) $-0.2(-1.7 \%)$ (women). Males more likely to be premature or miscarried.

Share of males: $-7.3 p p$ Gestation length: -1 week $(-0.28$ months) (boys only).

Exploit variation in cigarette taxes btw 1989-2007 at the state and municipal A $\$ 1$ dollar increase (in \$2009) in state cigarette excise tax:

levels. DD: identified off by variation in the timing \& size of changes in taxes Sick days from school: $-10 \%$ (no SD available on outcomes). across states \& over cohorts.

Models include state and year-month FE, demographic and state policy controls, and linear time trends.
2 or $>$ doctor visits in past year: $-4.5 \%$

Hospitalizations: $-19 \%$

Asthma attacks: -16\%.
Effects are twice as big on less educated mothers. Effects are significant for teen mothers but no effects for children of older moms. 
Table 2: Parental Investments

\begin{tabular}{|c|c|c|c|c|}
\hline Study & Micro - Data, N & $\begin{array}{l}\text { Identification strategy and } \\
\text { specification }\end{array}$ & Effects of the shock & $\begin{array}{c}\text { Heterogeneity in } \\
\text { mechanisms/effects }\end{array}$ \\
\hline $\begin{array}{l}\text { Adhvaryu and } \\
\text { Nyshadham (2016). } \\
\text { Impact of iodine } \\
\text { supplementation in } \\
\text { Tanzania on } \\
\text { parental } \\
\text { investments on } \\
\text { children 0-5. }\end{array}$ & $\begin{array}{l}\text { DHS 1999; representative of women } \\
\text { of reproductive age. } \\
\mathrm{N}=456 \text { children } 0-5 \text { (and their } \\
\text { mothers). }\end{array}$ & $\begin{array}{l}\text { Exploit the variation in in-utero exposure } \\
\text { to a large-scale iodine supplementation } \\
\text { program across districts. Linear Prob. } \\
\text { Models include rich controls \& district \& } \\
\text { child's age FE. } \\
\text { To test for resource allocation spillovers } \\
\text { across sibling, authors regress health } \\
\text { investments on own and sibs' } \\
\text { accumulated treatment. }\end{array}$ & $\begin{array}{l}\text { A } 1 \text { SD increase in treatment exposure: } \\
\text { Vaccination: }+0.2 \text { of a SD (polio } 0.16 \mathrm{pp} \text {, } \\
\text { measles } 4.5 \mathrm{pp} \text { ). } \\
\text { Breastfeeding }>=6 \mathrm{mths}:+0.1 \text { of a SD } \\
\text { ( } 3.5 \mathrm{pp} \text { ) (parents reinforce investments). } \\
\text { Siblings of treated children were more } \\
\text { likely to be immunized (no effects on } \\
\text { breastfeeding.) }\end{array}$ & $\begin{array}{l}\text { Vaccinations highly responsive to } \\
\text { parental observed benefits from the } \\
\text { program... even when treated child is } \\
\text { younger/older, younger/older siblings } \\
\text { are more likely to receive additional } \\
\text { investments (i.e.vaccination.) }\end{array}$ \\
\hline $\begin{array}{l}\text { Baker and Milligan } \\
\text { (2016). Ask how } \\
\text { differences in } \\
\text { parental time } \\
\text { investments are } \\
\text { related to gender } \\
\text { gaps in reading and } \\
\text { math scores in } \\
\text { Canada, the U.S., } \\
\text { and the U.K. at } \\
\text { school entry. }\end{array}$ & $\begin{array}{l}\text { 1) Canada: National Longitudinal } \\
\text { Survey of Children and Youth } \\
\text { (NLSCY); children born btw 1999- } \\
\text { 2004; } \\
\text { 2) US: Early Childhood Longitudinal } \\
\text { Survey-Birth Cohort (ECLS-B); children } \\
\text { born in 2001; } \\
\text { 3) UK: Millennium Cohort Study } \\
\text { (MCS); children born in 2000/2001; } \\
\text { N=was not reported. } \\
\text { 4) US data from: i) American Time } \\
\text { Use Survey (ATUS); waves 2003-2011; } \\
\text { ii) National Survey of Family Growth } \\
\text { (NSFG); waves: 2002 \& 2006-08; and } \\
\text { Canadian data from the Maternity } \\
\text { Experiences Survey (MES). }\end{array}$ & $\begin{array}{l}\text { Authors assume sex of 1st born child is } \\
\text { exogenous. } \\
\text { Model regressions include demographic } \\
\text { + SES controls and a dummy variable for } \\
\text { first born male child. } \\
\text { The authors investigate how parental } \\
\text { investments change with child's age } \\
\text { Twin FE: authors test the hypothesis that } \\
\text { parents treat opposite sex twins with } \\
\text { greater similarity than parents generally } \\
\text { treat sons and daughters (time inputs } \\
\text { were asked separately for each twin in } \\
\text { the UK data). }\end{array}$ & $\begin{array}{l}\text { Controlling for parental time inputs in } \\
\text { early life (ages 0-3) in baseline regressions } \\
\text { reduces: } \\
\text { Gender gap (boy/girl) in reading scores: } \\
-23 \% \text { in US, }-16 \% \text { in UK, }-33 \% \text { in Canada. } \\
\text { Gender gap in Math scores: } \\
-25 \% \text { in US, }-23 \% \text { in U.K., and }-33 \% \text { in } \\
\text { Canada. }\end{array}$ & $\begin{array}{l}\text { Boys have lower reading and math } \\
\text { scores at school entry. Authors argue } \\
\text { that this may be explained by } \\
\text { parental time inputs. }\end{array}$ \\
\hline
\end{tabular}




\begin{tabular}{|c|c|c|c|c|}
\hline Study & Micro - Data, N & $\begin{array}{l}\text { Identification strategy and } \\
\text { specification }\end{array}$ & Effects of the shock & $\begin{array}{c}\text { Heterogeneity in } \\
\text { mechanisms/effects }\end{array}$ \\
\hline $\begin{array}{l}\text { Bharadwaj and } \\
\text { Lakdawala (2013). } \\
\text { Investigate gender } \\
\text { differences in } \\
\text { prenatal care, } \\
\text { neonatal and early } \\
\text { childhood mortality } \\
\text { among mothers } \\
\text { who had an } \\
\text { ultrasound in India, } \\
\text { Bangladesh, and } \\
\text { China. }\end{array}$ & $\begin{array}{l}\text { 1) India: National Fertility and Health } \\
\text { Survey (NFHS), waves: 1998-1999, } \\
2005-2006 . \\
\text { 2) Bangladesh: Demography \& Health } \\
\text { Survey (DHS), waves: 1996-1997, } \\
\text { 1999- 2000, 2004, } 2007 . \\
\text { 3) China: Health and Nutrition Survey } \\
\text { (CHNS), waves: 1991, 1993, 1997, } \\
\text { 2000, 2004, 2006. } \\
\text { Authors also use DHS data for other } \\
\text { countries: Pakistan (2006-2007), } \\
\text { Ghana (1993, 1998, 2003, 2008), Sri } \\
\text { Lanka (1987), \& Thailand (1987). } \\
\mathrm{N}=32,012 .\end{array}$ & $\begin{array}{l}\text { Exploit the fact that some mothers had } \\
\text { ultrasounds (so could discriminate } \\
\text { prenatally) while others did not. If } \\
\text { mother did not have ultrasound can only } \\
\text { discriminate post-natally. Also expect } \\
\text { larger effects in places where sex } \\
\text { discimination is more severe (e.g. } \\
\text { Northern India). Models (linear \& logit) } \\
\text { include a dummy for gender of fetus, } \\
\text { mother/child controls (that includes } \\
\text { birth order, fam size, etc.), state FE \& } \\
\text { year of birth FE }\end{array}$ & $\begin{array}{l}\text { Mother pregnant with a boy: } \\
\text { Attended prenatal care at least twice per } \\
\text { week (India): }+1.8 \mathrm{pp}(3 \%)(+4.6 \% \text { in } \\
\text { Northern India where sex discrimination is } \\
\text { higher) } \\
\text { Tenanus: }+3 \% \text { (only sign. for Northern } \\
\text { India). } \\
\text { Results are only significant in the sample } \\
\text { of mothers who had an ultrasound. } \\
\text { No evidence of sex-selective prenatal care } \\
\text { in countries with weak or no son } \\
\text { preference (i.e., Ghana, Sri Lanka). } \\
\text { Tetanus shots can explain } 2.6-7.2 \% \text { of the } \\
\text { excess female neonatal mortality. }\end{array}$ & Larger effects in northern India. \\
\hline $\begin{array}{l}\text { Breining, Daysal, } \\
\text { Simonsen, and } \\
\text { Trandafir (2015). } \\
\text { Spillover effects of } \\
\text { medical treatments } \\
\text { received } \\
\text { by VLBW children } \\
\text { on their siblings. }\end{array}$ & $\begin{array}{l}\text { 1) Bith register data from Denmark } \\
\text { since } 1970 . \\
\text { 2) Emergency room } \\
\text { visits data (available between } 1995 \\
\text { and 2011), provides inpatient hospital } \\
\text { admissions \& mortality. } \\
\text { 3) Data on academic achievement } \\
\text { including 9th grade test scores } \\
\text { (available from 2002), high school } \\
\text { enrollment by age } 19 . \\
\text { Final sample }=3,677 \text { obs. }\end{array}$ & $\begin{array}{l}\text { RD that exploits changes in medical } \\
\text { treatment around the VLBW threshold } \\
\text { (as in Almond et al., 2010). } \\
\text { Treatment group: siblings of a child with } \\
\text { BW just below 1,500 grams \& with } 32 \text { or } \\
\text { more weeks of gestation } \\
\text { Control group: siblings of a child with } \\
\text { BW just above 1,500 grams \& with } 32 \text { or } \\
\text { more weeks of gestation. }\end{array}$ & $\begin{array}{l}\text { A child with a VLBW sibling (with } 32 \text { weeks } \\
\text { or more gestational length) who received } \\
\text { medical treatment due to this condition, } \\
\text { experiences: } \\
\text { Math test score (@age 15): +0.36 SD } \\
\text { Language test score (@age 15): +0.31 SD } \\
\text { High school enrollment (@age 15): +9.5pp } \\
(+30 \%) \\
\text { Mortality (28-day \& 1-year mortality) (ages } \\
0-15): \text { no effect } \\
\text { Diagnosis of intellectual disability <age 5: } \\
\text { no effect. }\end{array}$ & $\begin{array}{l}\text { Heterogeneity in the spillover effects } \\
\text { on sibling academic achievement } \\
\text { varies by sibship characteristics that } \\
\text { are most closely tied to the quality of } \\
\text { peer interactions (gender of sibling, } \\
\text { gender composition of the sibling } \\
\text { pair, and birth order). }\end{array}$ \\
\hline
\end{tabular}


Table 2: Parental Investments

\begin{tabular}{|c|c|c|c|c|}
\hline Study & Micro - Data, N & $\begin{array}{l}\text { Identification strategy and } \\
\text { specification }\end{array}$ & Effects of the shock & $\begin{array}{c}\text { Heterogeneity in } \\
\text { mechanisms/effects }\end{array}$ \\
\hline $\begin{array}{l}\text { Del Bono, Ermisch, } \\
\text { Francescon (2012). } \\
\text { Ask how smoking } \\
\text { and maternal work } \\
\text { stoppage before } \\
\text { birth affect } \\
\text { outcomes in the } \\
\text { U.S. and U.K., and } \\
\text { whether parents } \\
\text { respond to } \\
\text { idiosyncratic } \\
\text { changes in one } \\
\text { child's } \\
\text { endowments by } \\
\text { altering } \\
\text { investments in a } \\
\text { later child. }\end{array}$ & $\begin{array}{l}\text { Three large representative samples: } \\
\text { 1) UK: British Household Panel } \\
\text { Survey, longitudinal, 1991-2005, } \\
\mathrm{N}=1,339 \text { singletons } \\
\text { 2) UK: Millennium Cohort Study, } \\
\text { longitudinal, years of birth: } 2000 \text { \& } \\
2001, \mathrm{~N}=17,483 \text { singletons } \\
\text { 3) US: National Survey of Family } \\
\text { Growth, authors use the } 5 \text { th cycle } \\
\text { (1995), data is retrospective on } \\
\text { children who were born in } 1970- \\
\text { 1995, N=12,166 singletons. }\end{array}$ & $\begin{array}{l}\text { To address endogeneity of choice of } \\
\text { birth inputs, use method of moments } \\
\text { estimator (similar to an IV-FE that uses } \\
\text { prenatal inputs during earlier } \\
\text { pregnancies as instruments for } \\
\text { differences in inputs between } \\
\text { pregnancies). Identification assumption } \\
\text { is that prenatal inputs associated with a } \\
\text { specific pregnancy are uncorrelated } \\
\text { w/the idiosyncratic child endowments. } \\
\text { Authors estimate the direct effect of } \\
\text { inputs on birth outcomes (structural } \\
\text { parameters) \& the reduced form } \\
\text { parental responses to realized child } \\
\text { endowments when choosing the inputs } \\
\text { in successive pregnancies. }\end{array}$ & $\begin{array}{l}\text { 1) Maternal smoking during preg: } \\
\text { BW: }-190 \text { to }-200 \text { grams ( }-5.6 \%=-0.34 \text { of a } \\
\text { SD) (BHPS \& MCS datasets); }-139 \text { grams } \\
\text { (NSFG) (-4.2\% = }-0.24 \text { of a SD). } \\
\text { Fetal growth: }-5.4 \% \text { ( }-0.36 \text { of a SD) (BHPS); - } \\
4.1 \% \text { (-0.26 of a SD) (NSFG). } \\
\text { 2) } 3 \text { month-work stoppage in late preg: } \\
\text { BW: } 5.2 \% \text { ( } 0.3 \text { of a SD)(BHPS); } 1.8 \% \text { ( } 0.10 \\
\text { of a SD) (NSFG). } \\
\text { Fetal growth: } 3.5 \% \text { ( } 0.23 \text { of a SD) (BHPS); } \\
1.3 \% \text { ( } 0.08 \text { of a SD) (NSFG). } \\
\text { "Parents respond to idiosyncratic } \\
\text { endowment heterogeneity } \\
\text { in a way that is easier to reconcile with } \\
\text { inequity aversion." }\end{array}$ & $\begin{array}{l}\text { More educated women are less likely } \\
\text { to smoke and more likely to stop } \\
\text { working three months before birth } \\
\text { during their first three pregnancies. }\end{array}$ \\
\hline
\end{tabular}


Table 2: Parental Investments

\begin{tabular}{|c|c|c|c|c|}
\hline Study & Micro - Data, N & $\begin{array}{c}\text { Identification strategy and } \\
\text { specification }\end{array}$ & Effects of the shock & $\begin{array}{c}\text { Heterogeneity in } \\
\text { mechanisms/effects }\end{array}$ \\
\hline $\begin{array}{l}\text { Dizon-Ross (2014). } \\
\text { Investigate the } \\
\text { effect of providing } \\
\text { parents with } \\
\text { information } \\
\text { about their } \\
\text { children's true } \\
\text { achievement on } \\
\text { parental } \\
\text { investments. }\end{array}$ & $\begin{array}{l}\text { 1) Author conducted a sibling census } \\
\text { during January - March of } \\
2012 \text {, based on information on } \\
\text { children participating in } 39 \text { schools in } \\
\text { two districts in central Malawi (the } \\
\text { Machinga and } \\
\text { Balaka districts) } \\
\text { 2) Test data were gathered for all } \\
\text { periodic exams administered at } \\
\text { school } \\
\mathrm{N}=3,464 \text { households with at least } \\
2 \text { children enrolled in grades } 2-6\end{array}$ & $\begin{array}{l}\text { Randomly assigned half of the } \\
\text { households to a treatment group that } \\
\text { received information about their } \\
\text { children's recent achievement test } \\
\text { results in school, and half to a control } \\
\text { group, which did not receive } \\
\text { information }\end{array}$ & $\begin{array}{l}\text { The information delivered to parents } \\
\text { about their children's academic abilities: } \\
\text { (1) Parents' perceptions of their children's } \\
\text { achievement diverges from children's true } \\
\text { achievement: the gap is } 1 \text { SD. } \\
\text { (2) Parents reallocate educational } \\
\text { investments: Willingness-to-pay for } \\
\text { remedial math and English textbooks: } \\
+1.3 p p \text { in subjects in which children were } \\
\text { doing worse than expected. } \\
\text { Free subject-specific workbooks (remedial, } \\
\text { average, advanced): parents shifted their } \\
\text { choices towards workbooks that } \\
\text { corresponded more closely to their } \\
\text { children's true achievement level. }\end{array}$ & $\begin{array}{l}\text { Poorer, less-educated } \\
\text { parents have less accurate } \\
\text { perceptions about their children's } \\
\text { academic abilities than } \\
\text { richer, more-educated parents, and } \\
\text { update their beliefs more in response } \\
\text { to improved } \\
\text { information. }\end{array}$ \\
\hline $\begin{array}{l}\text { Cunha, Elo, and } \\
\text { Culhane (2015). } \\
\text { What would } \\
\text { happen to } \\
\text { investments \& child } \\
\text { development if a } \\
\text { policy that moved } \\
\text { expectations } \\
\text { from the median to } \\
\text { objective estimates } \\
\text { from the CNLSY/79 } \\
\text { data was } \\
\text { implemented? }\end{array}$ & $\begin{array}{l}\text { 1) Children of the National } \\
\text { Longitudinal Survey of Youth/1979 } \\
\text { (CNLSY/79); authors employ the } \\
\text { Motor-Social Development Scale; } \\
\text { N=335 African American mothers. }\end{array}$ & $\begin{array}{l}\text { Formulate a model of early childhood } \\
\text { development in which mothers have } \\
\text { subjective } \\
\text { expectations about the tech. of skill } \\
\text { formation. Empirically, the identification } \\
\text { of the model poses a problem: } \\
\text { preferences and beliefs are confounded. } \\
\text { To solve this problem, authors create a } \\
\text { survey instrument to elicit maternal } \\
\text { expectations about the tech. of skill } \\
\text { formation. Mothers are asked: "what is } \\
\text { the youngest and oldest age at which } \\
\text { your baby will learn how to do task X or } \\
\text { Y?" (the tasks are taken from the } \\
\text { Motor-Social Development Scale of the } \\
\text { CNLSY/79 and NHANES). Authors exploit } \\
\text { within-family variation to estimate the } \\
\text { parameters of the technology of skill } \\
\text { formation. }\end{array}$ & $\begin{array}{l}\text { 1) Mothers underestimate the elasticity of } \\
\text { child development w.r.t. investments: } \\
\text { Mothers' subjective expectation about the } \\
\text { elasticity of their child developm't w.r.t. } \\
\text { investments is btw } 4-19 \% \text {, but authors } \\
\text { estimate ndicates elasticities btw } 21-36 \% \text {. } \\
\text { 2) A policy that moved expectations from } \\
\text { the median to objective estimates would } \\
\text { increase investment by } 4 \% \text { to } 24 \% \text { and } \\
\text { stocks of cognitive skills } 24 \text { months would } \\
\text { increase by } 1 \% \text { to } 5 \% \text {. The impacts of such } \\
\text { a policy would be even higher for mothers } \\
\text { whose expectations were < the median. }\end{array}$ & NA \\
\hline
\end{tabular}




\begin{tabular}{|c|c|c|c|c|}
\hline Study & Micro - Data, N & $\begin{array}{l}\text { Identification strategy and } \\
\text { specification }\end{array}$ & Effects of the shock & $\begin{array}{c}\text { Heterogeneity in } \\
\text { mechanisms/effects }\end{array}$ \\
\hline $\begin{array}{l}\text { Fryer, Levitt, and } \\
\text { List (2015). Effect } \\
\text { of parental } \\
\text { incentives on early } \\
\text { childhood cognitive } \\
\text { and non-cognitive } \\
\text { achievement. }\end{array}$ & $\begin{array}{l}\text { Longitudinal data collected for the } \\
\text { study includes pre-test characteristics } \\
\text { of the sample of children \& families } \\
\text { (year of data collection is 2011), } \\
\text { children's test scores in the middle of } \\
\text { the treatment year (January 2012) \& } \\
\text { at the end of treatment (May 2012) } \\
N=260 \text { families. }\end{array}$ & $\begin{array}{l}\text { Randomized field experiment. Families } \\
\text { were randomly assigned to } 3 \text { groups: } \\
\text { 1: parents paid in cash or via direct } \\
\text { deposits for attendance at early- } \\
\text { childhood sessions; } \mathrm{N}=74 \text {; Treatment 2: } \\
\text { parents paid for attendance in early- } \\
\text { childhood program attendance via } \\
\text { deposits into a trust which can only be } \\
\text { accessed when the child enrolls in } \\
\text { college; } \mathrm{N}=84 \text {; Control group: parents } \\
\text { not paid \& did not attend early- } \\
\text { childhood sessions; } \mathrm{N}=99 \text {. }\end{array}$ & $\begin{array}{l}\text { Children of parents who participate in the } \\
\text { intervention: } \\
\text { Cognitive (PPVT; Woodcock Johnson III } \\
\text { Test of Achievement scores): no effect. } \\
\text { Non-cognitive (Blair and Willoughby } \\
\text { Executive Function scores, Preschool Self- } \\
\text { Regulation Assessment score): }+0.23 \text { SD. }\end{array}$ & $\begin{array}{l}\text { Positive effects only among whites } \\
\text { and Hispanics (little impact on Black } \\
\text { children). } \\
\text { Students who started below the } \\
\text { median non-cognitive skills, } \\
\text { experienced no benefits in cognitive } \\
\text { or non-cognitive outcomes, while } \\
\text { those who started with above the } \\
\text { median non-cognitive skills, } \\
\text { experienced increases on both } \\
\text { cognitive \& non-cognitive skills. }\end{array}$ \\
\hline $\begin{array}{l}\text { Hsin (2012). Ask } \\
\text { whether maternal } \\
\text { time investments } \\
\text { from 0-12 } \\
\text { compensate or } \\
\text { reinforce birth } \\
\text { weight differences } \\
\text { and whether } \\
\text { effects differ by } \\
\text { SES. }\end{array}$ & $\begin{array}{l}\text { 1) Time diaries from the PSID-CDS; } \\
\text { time diaries are child-specific, the } \\
\text { PSID collected time diaries \& child } \\
\text { info for up to two randomly selected } \\
\text { children within each family; time- } \\
\text { diaries sample weekdays \& weekends } \\
\text { for } 24 \text { hours; N1,516 children, or } 758 \\
\text { sibling pairs. }\end{array}$ & $\begin{array}{l}\text { Sibling FE stimates of the effect of birth } \\
\text { endowments on parental investments \& } \\
\text { include interactions between child } \\
\text { endowment \& characteristics such as } \\
\text { mother's education or family income } \\
\text { Models include rich controls, } \\
\text { interactions between birth } \\
\text { endowments*SES, and splines to } \\
\text { measure family SES. }\end{array}$ & $\begin{array}{l}\text { Overall effect of birth endowments on } \\
\text { parental time investments \& the } \\
\text { interaction between BW*mother's } \\
\text { characteristics: } \\
\text { Total hours per week: no effect } \\
\text { Hours devoted to activities that develop } \\
\text { the child's human capital (reading, playing, } \\
\text { doing hobbies, etc): no effect. }\end{array}$ & $\begin{array}{l}\text { By mother's educ: College educated } \\
\text { mothers compensate by investing } \\
\text { more in LBW children: children } \\
\text { receive }+0.65 \text { SD (total time), }+1 \text { SD } \\
\text { (educational time). } \\
\text { Mothers with }<=12 \text { years of } \\
\text { education concentrate resources on } \\
\text { higher BW children: non-LBW } \\
\text { children receiv }+0.17 \text { SD total time \& - } \\
0.10 S D \text { educational time than LBW } \\
\text { siblings. }\end{array}$ \\
\hline
\end{tabular}


Table 2: Parental Investments

\begin{tabular}{|c|c|c|c|c|}
\hline Study & Micro - Data, N & $\begin{array}{c}\text { Identification strategy and } \\
\text { specification }\end{array}$ & Effects of the shock & $\begin{array}{c}\text { Heterogeneity in } \\
\text { mechanisms/effects }\end{array}$ \\
\hline $\begin{array}{l}\text { Yi, Heckman, } \\
\text { Zhang, and Conti } \\
\text { (2014). Asks how } \\
\text { Chinese parents } \\
\text { alter investments in } \\
\text { twins at ages 6-18 } \\
\text { in response to the } \\
\text { serious illness of } \\
\text { one twin at age 0- } \\
\text { 3. }\end{array}$ & $\begin{array}{l}\text { Chinese Child Twins Survey (CCTS); } \\
\text { includes detailed info on family } \\
\text { health \& educ investments for } \\
\text { e/child; conducted in } 2002 \text { to } 2003 \text { in } \\
\text { the province of Kunming, China; } \\
\mathrm{N}=1,694 \text { households with twins. }\end{array}$ & $\begin{array}{l}\text { Early health shocks affect children both } \\
\text { biologically and by affecting parental } \\
\text { responses. Assume that "the within- } \\
\text { twin variation in early health shocks is } \\
\text { random and exogenous." } \\
\text { To estimate effects of health shocks on } \\
\text { child's outcomes and address the } \\
\text { possibility that family investments may } \\
\text { be endogenous, authors use an IV based } \\
\text { on within-twin variations in BW, gender } \\
\text { and HH level variables (rural indicator, } \\
\text { maternal working sector, age, ethnicity, } \\
\text { and schooling). }\end{array}$ & $\begin{array}{l}\text { When a twin child suffered from a serious } \\
\text { disease at ages 0-3: } \\
\text { Parental investments: } \\
\text { Health investments in the sick twin (\$ } \\
\text { spent on medical treatment, medicine, } \\
\text { health products): + RMB } 305 \text { (+\$49 US) } \\
\text { (+35\% = +0.39 SD). } \\
\text { Educational investments in the sick twin } \\
\text { (tuition + \$ spent on books, stationery, } \\
\text { home tutors, tutoring class): RMD -182 (- } \\
\$ 30 \text { US) (-20\% = -0.15 SD). } \\
\text { Child outcome results suggest that } \\
\text { parental investments equalize health but } \\
\text { increase disparities in education in favor of } \\
\text { the healthier twin. }\end{array}$ & $\begin{array}{l}\text { Rural areas: Increase in health } \\
\text { expenditures in favor of the sick twin } \\
\text { is not accompanied by a decrease in } \\
\text { educational expenditures. } \\
\text { Urban areas: the fall in educational } \\
\text { expenditures on the sick child offsets } \\
\text { the cost of medical expenses. } \\
\text { Compensating investments and } \\
\text { reinforcing educational investments } \\
\text { are more precisely determined } \\
\text { among high education mothers and in } \\
\text { female twins. Wealthier households } \\
\text { have more reinforcing educational } \\
\text { investments. }\end{array}$ \\
\hline
\end{tabular}




\begin{tabular}{|c|c|c|c|c|}
\hline Study & Micro - Data, N & Identification strategy and specification & Effects of the shock & Heterogeneity \\
\hline \multicolumn{5}{|c|}{ Panel A: Policies to Increase Material Household Resources } \\
\hline $\begin{array}{l}\text { Adhvaryu, Fenske, } \\
\text { and Nyshadham } \\
\text { (2016). Effects of } \\
\text { cocoa price shocks } \\
\text { in Ghana in year of } \\
\text { birth on mental } \\
\text { and physical adult } \\
\text { health. }\end{array}$ & $\begin{array}{l}\text { 1) Cocoa prices time series. } \\
\text { 2) EGC-ISSER Socioeconomic Panel; } \\
\text { baseline data on cocoa production Nov. } \\
2009 \text { to April 2010; plots of land \& type } \\
\text { of crops, } 10 \text { regions; data also includes } \\
\text { Kessler Psychological Distress scale-10 } \\
\text { questions. N= 7,741 individuals. } \\
\text { 3) Demographic and Health Survey; } \\
\text { waves: } 1988,1993,1998,2003,2008 ; \\
\text { nationally representative cross-sections } \\
\text { women } 15-49 \text {. }\end{array}$ & $\begin{array}{l}\text { HH's in the cocoa-producing regions of Ghana } \\
\text { experience changes in the real producer price of } \\
\text { cocoa as income shocks, while HH's in regions } \\
\text { that do not produce cocoa are unaffected by } \\
\text { these fluctuations. } \\
\text { Linear models include region r and year of birth t } \\
\text { FE and individual and HH controls; some } \\
\text { specifications include region linear \& quadratic } \\
\text { time trends, rainfall \& temperature controls, as } \\
\text { well as household FE. }\end{array}$ & $\begin{array}{l}\text { A } 1 \text { SD rise in the cocoa price in the year } \\
\text { of birth: } \\
\text { Kessler Psychological Distress scale: }-2 \mathrm{pp} \\
\text { (-0.08 SD; }-1.0 \%) \text {. } \\
\text { Severe distress (Kessler scale>10): -3pp (- } \\
0.13 \text { SD; }-4.5 \%) \text {. } \\
\text { Physical health: } \\
\text { Height: }+1.23 \mathrm{~cm} \text { (no avg. height } \\
\text { provided in descriptive stats) } \\
\text { BMI, savings, occupation: no effect. }\end{array}$ & $\begin{array}{l}\text { By gender: very mild differences across } \\
\text { males and females. } \\
\text { By timing of exposure: Shocks in the } \\
\text { first } 4 \text { years of life have significant } \\
\text { - effects, though effects are largest in } \\
\text { the YOB. }\end{array}$ \\
\hline $\begin{array}{l}\text { Almond, Hoynes, } \\
\text { and Schazenbach } \\
\text { (2011). Effects of } \\
\text { introduction of the } \\
\text { U.S. Food Stamp } \\
\text { Program on birth } \\
\text { weight and } \\
\text { fertility. }\end{array}$ & $\begin{array}{l}\text { Vital statistics - Natality \& death records } \\
\text { 1959-1977; N 2M observations per year. } \\
\text { SEER population data (to construct } \\
\text { fertility rates). }\end{array}$ & $\begin{array}{l}\text { Use the county-by-county rollout of the FSP. } \\
\text { Model regressions include county level controls, } \\
\text { county and year of birth FE, state*year FE, } \\
\text { interactions of pretreatment county } \\
\text { characteristics with time trends. } \\
\text { Event time study: Authors do not have } \\
\text { information about FS participation or data to } \\
\text { impute eligibility (e.g., income). So they use the } \\
1980 \text { CPS to calculate FSP participation rates for } \\
\text { women with a child <5. }\end{array}$ & $\begin{array}{l}\text { Food stamps during pregnancy increase } \\
\text { BW by: } \\
\text { Whites }+2.04 \text { gr (effect size }=0.06 \% \text { ) } \\
\text { Blacks }+3.45 \mathrm{gr} \text { (e.s. }=0.08 \% \text { ). } \\
\text { Estimate of TOT effect (after adjusting } \\
\text { by participation rate) on BW: } \\
\text { Whites: }+15 \text { to } 20 \mathrm{gr} \text { (effect size: } 0.5- \\
0.6 \%) \\
\text { Blacks: }+13 \text { to } 42 \mathrm{gr}(0.4-1.4 \%) \\
\text { No statistically significant effects on } \\
\text { fertility or neonatal mortality. }\end{array}$ & $\begin{array}{l}\text { Largest impacts at lower BWs. LBW: - } \\
7 \% \text { for whites, }-5 \% \text { to }-11 \% \text { for blacks. } \\
\text { Poor counties face }+3.41 \mathrm{~g} \text { BW, no } \\
\text { effect in wealthier counties. Larger } \\
\text { effects in the South and in urban } \\
\text { counties. } \\
\text { Larger impacts for older mothers. } \\
\text { Black single mothers experienced larger } \\
\text { impacts than all black women. }\end{array}$ \\
\hline
\end{tabular}




\begin{tabular}{|c|c|c|}
\hline Study & Micro - Data, $\mathbf{N}$ & Identification strategy and specification \\
\hline \multicolumn{3}{|c|}{ Panel A: Policies to Increase Material Household Resources } \\
\hline $\begin{array}{l}\text { Aizer, Eli, Ferrie, } \\
\text { and Lleras-Muney } \\
\text { (2016). Examines } \\
\text { the long run effects } \\
\text { of the US Mother's } \\
\text { Pension Program } \\
\text { on child survival by } \\
\text { comparing } \\
\text { mothers who were } \\
\text { accepted and those } \\
\text { who were rejected } \\
\text { from the program. }\end{array}$ & $\begin{array}{l}\text { 1) Individual-level administrative records } \\
\text { of applicants to the Mothers' Pension } \\
\text { program: } \\
\mathrm{N}=16,000 \text { children from } 11 \text { states who } \\
\text { were born } 1900-1925 \text {. } \\
\text { 2) WWII enlistment records. } \\
\text { 3) } 1940 \text { census records. } \\
\text { 4) Social Security Death Master File } \\
\text { (DMF); name, date of birth, date of } \\
\text { death, SSN for } 88 \text { million deaths } \\
\text { reported from } 1965-2012 \text {. } \\
\text { Authors matched administrative data to } \\
\text { census, WWII, \& death records. Able to } \\
\text { match } 48 \% \text { of sample to a unique death } \\
\text { record. Females could not be matched } \\
\text { due to name changes. }\end{array}$ & $\begin{array}{l}\text { Compare children of mothers who applied to the } \\
\text { MP transfers \& were given the receipt, to the } \\
\text { children of mothers who applied for transfers } \\
\text { but were denied. Rejected mothers were on } \\
\text { average slightly better-off based on observable } \\
\text { characteristics. Hence, the effects of the } \\
\text { program are likely to understate the benefits of } \\
\text { the program. } \\
\text { Models include state-level, time-varying } \\
\text { characteristics (i.e., ratio of state manufacturing } \\
\text { earnings to national manufacturing earnings, } \\
\text { laws governing school attendance, expenditures } \\
\text { on social programs, education \& charitable } \\
\text { institutions, hospitals \& prisons); county-level } \\
\text { characteristics in 1910, county \& cohort FE. }\end{array}$ \\
\hline
\end{tabular}

and Lleras-Muney of applicants to the Mothers' Pension

the US Mother's were born 1900-1925.
Effect of access to the Mother's Pension Effects are driven by the poorest program:

Longevity: +1.5 years $(+2.1 \%)$ (no

standard deviations provided in

descriptives).

Prob(of survival past age 70 ): $+10-20 \%$.

Prob(of survival past age 80 ): $9-15 \%$

families in the sample.

the program.

facturin

on social programs, education \& charitable

record. Females could not be matched characteristics in 1910, county \& cohort FE.

due to name changes.

Akee, Simeonova, The "Great Smoky Mountains Study of

Costello, et al

outh": longitudinal survey of 1,420

(2015). The effect children aged 9, 11, 13 years at the

of a permanent

increase in

unearned

household income $\mathrm{N}=6,050$ children.

on children's

emotional,

behavioral, health,

and personality

traits.
A casino opened on the Eastern Cherokee

reservation and part of profits were distributed

per capita to all adult tribal members (Transfer=

SNAP).

DD: Compare outcomes for adolescents who

resided in households with extra income

(youngest and middle age cohorts of American

Indian children) to adolescents who were not

exposed to the extra income by age 16 (the

oldest age cohort).

Models include individual FE, age $\mathrm{FE}$, age* race $\mathrm{FE}$
Child resides in a household that

due to the casino revenues:

avioral disorders: -0.27 SD

Emotional disorders: -0.36 SD

Personality traits:

Conscientiousness: -0.43 SD

Agreeableness: -0.31 SD

Neuroticism: no effect

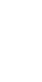

(n)

Income transfer improved child

outcomes through better parent-child relationsp and not necessarily through more parental time investments "parents who receive the $\$$ provide investments in their childrenwith lower than avg. personality traits and lower than avg. amounts of behavioral and emotional problems" (i.e., compensatory responses) 


\begin{tabular}{|c|c|c|c|c|}
\hline Study & Micro - Data, $\mathbf{N}$ & Identification strategy and specification & Effects of the shock & Heterogeneity \\
\hline \multicolumn{5}{|c|}{ Panel A: Policies to Increase Material Household Resources } \\
\hline $\begin{array}{l}\text { Barham, Macours, } \\
\text { and Maluccio } \\
\text { (2013). Examine } \\
\text { the effect of } \\
\text { Conditional Cash } \\
\text { Transfers received } \\
\text { in utero to age } 2 \\
\text { vs. ages 2-5 in } \\
\text { Nicaragua on } \\
\text { cognitive and } \\
\text { health outcomes. }\end{array}$ & $\begin{array}{l}\text { 1) Household data from the phase -in \& } \\
\text { follow-up of the randomized CCT } \\
\text { experiment; years } 2000 \& 2010 ; \\
\mathrm{N}=171 \text { boys in the "early treatment" } \\
\text { group + } \mathrm{N}=197 \text { boys in the "late } \\
\text { treatment group" born up to } 1 \text { year after } \\
\text { CCT started (Oct, 2001). }\end{array}$ & $\begin{array}{l}42 \text { localities in } 6 \text { municipalities were randomized } \\
\text { into early-treatment ( } 21 \text { ) vs. late treatment ( } 21) \text {; } \\
\text { groups were stratified by their poverty level } \\
\text { Treatment group - "early-treatment" boys were } \\
\text { exposed to the program from in-utero to age } 2 \text {. } \\
\text { Control group "late treament" boys were } \\
\text { exposed from ages } 2 \text { to } 5 \text {. } \\
\text { Models include birth month FE, stratification } \\
\text { dummies to account for the stratification in the } \\
\text { randomization (i.e., poverty). }\end{array}$ & $\begin{array}{l}\text { Boys exposed to the program in utero up } \\
\text { to age } 2 \text { vs. ages } 2-5 \text { : } \\
\text { Cognitive outcomes: }+0.15 \text { SD } \\
\text { Anthropometrics: no effect. }\end{array}$ & NA \\
\hline $\begin{array}{l}\text { Bharadwaj, } \\
\text { Lundborg, and } \\
\text { Rooth (2014). } \\
\text { Explore whether } \\
\text { low birth weight } \\
\text { affects how one is } \\
\text { affected during } \\
\text { economic } \\
\text { downturns. }\end{array}$ & $\begin{array}{l}\text { 1) Swedish registry data on births: data } \\
\text { on all twins born in 1929-1956; } N=5,000 \\
\text { twins. } \\
\text { 2) UREG: data on individual years of } \\
\text { schooling, 1990-2007. } \\
\text { 3) Income data: equivalent of W2 } \\
\text { records in the US, 1981-2005. } \\
\text { 4) Statistics Sweden: provides info on } \\
\text { occupation for } 1985 \text { and } 1990 .\end{array}$ & $\begin{array}{l}\text { Compare cohorts who were born years before } \\
\text { the economic crisis (1985-1990) with cohorts } \\
\text { born few years after the crisis (1993-1998); } \\
\text { Include twin FE. } \\
\text { Assumptions: } \\
\text { Post-birth investments within twin pairs are not } \\
\text { correlated to birth weight. }\end{array}$ & $\begin{array}{l}\text { A } 10 \% \text { increase in BW: } \\
\text { Receives unemployment insurance: }-1 \% \\
\text { (no SD available) } \\
\text { Years receiving UI: }-0.4 \text { years (-80\%) } \\
\text { "a } 10 \% \text { increase in BW (approx. } 260 \\
\text { grams) results in a } 0.008 p p \text { lower prob } \\
\text { of being on unemp insurance." }\end{array}$ & $\begin{array}{l}\text { One potential mechanism driving the } \\
\text { effects is "occupational sorting in the } \\
\text { pre- crisis years". Affected cohorts } \\
\text { were less likely to be employed in the } \\
\text { public sector and less likely to enter a } \\
\text { white collar job. }\end{array}$ \\
\hline $\begin{array}{l}\text { Black, Devereux, } \\
\text { Løken, and } \\
\text { Salvanes (2014). } \\
\text { Effect of a } 1 \text { year } \\
\text { childcare subsidy } \\
\text { at age } 5 \text { on } \\
\text { parental behavior } \\
\text { and teen GPA. }\end{array}$ & $\begin{array}{l}\text { 1) Administ. data covering the entire } \\
\text { population of Norway, cohorts: } 1986- \\
\text { 1992; authors link individuals to their } \\
\text { parents through unique identifiers. } \\
\mathrm{N}=367,836 \text { obs. } \\
\text { 2) Municipality-level data on childcare } \\
\text { prices and family income cutoffs in the } \\
\text { 1990s. }\end{array}$ & $\begin{array}{l}\text { Exploit sharp discontinuities in the price of } \\
\text { childcare (CC) by income. } \\
\text { Compare outcomes of children whose HH } \\
\text { income was just less than a cutoff to those of } \\
\text { children whose HH income was just above a } \\
\text { cutoff. } \\
\text { Also estimate a parametric specification that } \\
\text { controls for indiv/HH charact \& cohort by } \\
\text { municipality FE, as well as sibling FE. }\end{array}$ & $\begin{array}{l}\text { Being eligible for lower CC prices at age } \\
5: \\
\text { No change in use of child care, so } \\
\text { subsidy only increased income. } \\
\text { GPA: }+0.30 \text { of a SD } \\
\text { Oral exam grade: }+0.30 \text { of a SD } \\
\text { Main result: A } 1 \% \text { increase in family } \\
\text { income at age } 5 \text { : would increase scores } \\
\text { by about } 0.04 \text { of a SD } \\
\text { Sibling FE: similar by less precise. }\end{array}$ & \\
\hline
\end{tabular}




\begin{tabular}{|c|c|c|c|c|}
\hline Study & Micro - Data, N & Identification strategy and specification & Effects of the shock & Heterogeneity \\
\hline \multicolumn{5}{|c|}{ Panel A: Policies to Increase Material Household Resources } \\
\hline $\begin{array}{l}\text { Chetty, Hendren, } \\
\text { and Katz (2015). } \\
\text { Examine two } \\
\text { hypotheses: 1) } \\
\text { moving to a lower- } \\
\text { poverty } \\
\text { neighborhood } \\
\text { improves LT outc. } \\
\text { for children who } \\
\text { moved young? } \\
\text { 2) the gains decline } \\
\text { with child's age at } \\
\text { move? }\end{array}$ & $\begin{array}{l}\text { 1) Moving to Opportunity data includes } \\
\text { demographic, SES, school data, criminal } \\
\text { victimization, income, transfer receipt; } \\
\text { There are } 11,276 \text { children in the MTO } \\
\text { data, of whom } 8,603 \text { ( } 76 \% \text { ) were born <= } \\
1991 \text {. } \\
\text { ii) annual data on residential } \\
\text { neighborhood (census tract) using } 1990 \\
\& 2000 \text { Censuses; } 2005-2009 \text { American } \\
\text { Community Surveys. } \\
\text { 2) Federal income tax returns data, } 1996- \\
\text { 2012. *MTO records were linked to the } \\
\text { tax data by SSN ( } 86 \% \text { success). }\end{array}$ & $\begin{array}{l}\text { Experiment: families were randomly assigned to } \\
3 \text { groups. } \\
\text { 1) Experimental grp: was offered subsidized } \\
\text { housing voucher + requirement to move to a } \\
\text { census tract w/poverty rate }<10 \% \text {. } \\
\text { 2) Section } 8 \text { voucher grp: was offered a standard } \\
\text { subsidized housing voucher w/no additional } \\
\text { contingencies. } \\
\text { 3) Control grp: was not offered a voucher (but } \\
\text { retained access to public housing). } \\
\text { *Authors replicate ITT models as in Kling et al. } \\
\text { (2007). } \\
\text { Models also include interactions of age at RA * } \\
\text { treatment indicators. }\end{array}$ & $\begin{array}{l}\text { Effects on children <age 13: } \\
\text { 1) Voucher (experimental) group } \\
\text { Income: } \$ 1,624(+14 \%) \text {. } \\
\text { Attends college: }+2.5 p p(+15 \%) \\
\text { Prob(live in a poor neighborhood as an } \\
\text { adult): }-4 \% \\
\text { Prob(single parent): }-15 \% \text { (only for } \\
\text { females) } \\
\text { 2) Section } 8 \text { Income: no effect. } \\
\text { Attends college: no effect } \\
\text { Prob(live in a poor neighborhood as an } \\
\text { adult): }-7 \% \\
\text { Prob(single parent): no effect } \\
\text { Effects on children >=age } 13 \\
\text { Little (or sometimes negative) effects on } \\
\text { older children. }\end{array}$ & $\begin{array}{l}\text { Gains from moving to lower-poverty } \\
\text { areas decline with child's age at move. } \\
\text { The extra federal income taxes that } \\
\text { young children in the experimental } \\
\text { group would obtain during their mid- } \\
\text { twenties, would offset the incremental } \\
\text { cost of providing voucher treatment } \\
\text { relative to providing public housing }\end{array}$ \\
\hline $\begin{array}{l}\text { Dahl and Lochner } \\
\text { (2012). Effects of } \\
\text { changes in U.S. } \\
\text { Earned Income Tax } \\
\text { Credit on child test } \\
\text { scores, mean } \\
\text { age }=11 \text { at testing. }\end{array}$ & $\begin{array}{l}\text { 1) Child Supplements of the NLSY, } \\
\text { longitudinal data, } N=4,500 \text { children. } \\
\text { Includes PIAT scores for children } 5+\text { from } \\
1988 \text { to } 2000 \text { (biannually). (Children took } \\
\text { each individual test at most } 5 \text { times.) } \\
\mathrm{N}=4,412 \text { children born to } 2,401 \\
\text { mothers. }\end{array}$ & $\begin{array}{l}\text { Identification comes primarily from the } \\
\text { substantial expansion } \\
\text { of the EITC schedule between } 1993 \text { and } 1995 . \\
\text { Child FE + IV (instrument for HH income: } \\
\text { predicted EITC income due to regulatory changes } \\
\text { \& not due to changes in family structure). } \\
\text { Models include year FE, controls for other state- } \\
\text { level policies, a fifth-order polynomial in lagged } \\
\text { pretax income \& an indicator for positive lagged } \\
\text { pretax income as a baseline "control function", } \\
\text { national trends. }\end{array}$ & $\begin{array}{l}\text { A } \$ 1,000 \text { increase in income: } \\
\text { PIAT score (combined math \& reading } \\
\text { test scores): }+0.06 \text { SD. } \\
\text { Reading recognition: }+0.04 \text { SD. } \\
\text { Reading comprehension: }+0.06 \text { SD. } \\
\text { Math: } 0.06 \text { SD. } \\
\text { 1st stage coefficient: } 1.270 * * \\
\text { Overall effect: from } 1987-1999 \text {, the } \\
\text { median EITC payment for eligible two- } \\
\text { child families increased by } \$ 1,670 \text { ( } 2000 \\
\text { dollars), implying a test score increase of } \\
0.010 \text { of a SD for this group. }\end{array}$ & $\begin{array}{l}\text { Test gains are larger for children from } \\
\text { disadvantaged families (minorities: } \\
+0.08 \text { SD, children in unmarried } \\
\text { families: }+0.08 \text { SD, children of mothers } \\
\text { with HS or less educ: }+0.05 \text { SD), for } \\
\text { younger children (ages }<12 \text { the effect is: } \\
+0.08 \text { SD), and for boys ( }+0.09 \mathrm{SD} \text { ). }\end{array}$ \\
\hline
\end{tabular}




\begin{tabular}{|c|c|c|c|}
\hline Study & Micro - Data, N & Identification strategy and specification & Effects of the shock \\
\hline \multicolumn{4}{|c|}{ Panel A: Policies to Increase Material Household Resources } \\
\hline $\begin{array}{l}\text { Del Boca, Flinn, } \\
\text { and Wiswall } \\
\text { (2013). Asks how } \\
\text { cash transfers } \\
\text { affect parental } \\
\text { investments in } \\
\text { children in the U.S. }\end{array}$ & $\begin{array}{l}\text { 1) Longitudinal data from Child } \\
\text { Development Supplement of the PSID; } \\
\text { first } 2 \text { waves (CDS-I \& CD-II) } 1997 \& 2002 \\
\text { 3, include child time diaries \& rich } \\
\text { demographic and SES HH data, N=3,500 } \\
\text { children residing in 2,400 HH (authors } \\
\text { also use the PSID waves 1997, 1999, } \\
2001,2003 \text { ). }\end{array}$ & $\begin{array}{l}\text { Authors estimate the parameters of a } \\
\text { production function for child outputs using a } \\
\text { - Cobb-Douglas production function \& simulation } \\
\text { methods (using PSID-CDS data). }\end{array}$ & $\begin{array}{l}\text { Estimates suggest that parental time } \\
\text { inputs are more valuable than monetary } \\
\text { inputs in producing child quality. Time is } \\
\text { relatively most valuable when children } \\
\text { are young. Suggests that monetary } \\
\text { transfers may have small impacts on } \\
\text { child quality because a significant } \\
\text { fraction of thetransfer is spent on other } \\
\text { HH consumption and the leisure of the } \\
\text { parents. }\end{array}$ \\
\hline
\end{tabular}

\begin{tabular}{|c|c|c|c|c|}
\hline $\begin{array}{l}\text { Hoynes, Miller, and } \\
\text { Simon (2012). } \\
\text { Effects of changes } \\
\text { in U.S. Earned } \\
\text { Income Tax Credit } \\
\text { on incidence of low } \\
\text { birth weight. }\end{array}$ & $\begin{array}{l}\text { 1) Vital Statistics micro data, } 1984-1999 \text {, } \\
\text { collapsed to cells defined by state, } \\
\text { month-year, parity of birth, mother's } \\
\text { education, marital status, race, age; } \\
\mathrm{N}=47,687 \text { cells. } \\
\text { 2) March Current Population Survey } \\
\text { combined with the NBER TAXSIM model } \\
\text { to compute average EITC benefits. }\end{array}$ & $\begin{array}{l}\text { Exploit tax-reform (1986, 1990, 1993) induced } \\
\text { variation in the federal EITC across time \& family } \\
\text { size. } \\
\text { 1) DD: Compare } 2 \text { nd \& higher order births } \\
\text { (treatment) to 1st births (control). } \\
\text { Models include effective tax year FE, state FE, \& } \\
\text { rich demographic controls. } \\
\text { 2) Event study. } \\
\text { 3) Panel FE model to measure the generosity of } \\
\text { the EITC using the maximum EITC credit. }\end{array}$ & $\begin{array}{l}\text { 2nd parity or higher births, relative to } \\
\text { 1st births: } \\
\text { LBW: }-3.5 \% \text { for the full sample (no SD } \\
\text { available) (effects are larger for } 3 \text { rd or } \\
\text { higher order births than } 2 \text { nd births). } \\
\text { An increase of } \$ 1000 \text { treatment on the } \\
\text { treated (TOT): LBW: }-6.7 \% \text {. }\end{array}$ & $\begin{array}{l}\text { LBW: larger effects (-10.8\%) for infants } \\
\text { of single and less educated mothers. } \\
\text { By race: African American infants } \\
\text { largest reduction in LBW (-5.1\% vs. } \\
\text { whites }-1.6 \%) \text {. } \\
\text { Effects on Hispanics are small (-1.9\%). }\end{array}$ \\
\hline $\begin{array}{l}\text { Hoynes, } \\
\text { Schazenbach, and } \\
\text { Almond (2016). } \\
\text { Effect of exposure } \\
\text { to the U.S. Food } \\
\text { Stamp Program } \\
\text { (FSP) from 0-5 } \\
\text { years on adult } \\
\text { health (age } 25 \\
\text { plus). }\end{array}$ & $\begin{array}{l}\text { Panel Study of Income Dynamics (PSID); } \\
3,000 \text { HHs; use waves until } 2009 . \\
\text { The "Survey of Economic Opportunity } \\
\text { subsample"; N=1,900 low-income \& } \\
\text { minority HHs selected from an existing } \\
\text { sample (adjust for nonrandom sample } \\
\text { using PSID weights). }\end{array}$ & $\begin{array}{l}\text { DD model: Exploit variation in roll-out of FSP } \\
\text { across counties \& over birth cohorts in exposure } \\
\text { to the FSP. } \\
\text { DDD: use variation across subgroups w/varying } \\
\text { propensities to use FSP. } \\
\text { Models include controls for county, year of birth, } \\
\text { interview FE, state linear time trends, county-yr } \\
\text { of birth controls. }\end{array}$ & $\begin{array}{l}\text { Increasing the share from no FSP } \\
\text { exposure to full exposure in utero to age } \\
\text { 5): Metabolic syndrome Z-score (obesity, } \\
\text { high blood pressure, diabetes, heart } \\
\text { attack): - } 0.3 \text { SD (TOT: }-0.24 \text { SD) (largest } \\
\text { effects on males } 0.5 \text { SD). } \\
\text { Weak improvements in other health } \\
\text { outcomes: diabetes, health status, } \\
\text { disability, smoking. Gains from FSP are } \\
\text { large and increasing with exposure up to } \\
\text { age } 5 \text {. }\end{array}$ & $\begin{array}{l}\text { Largest effects on males: } 0.5 \text { of a SD. } \\
\text { Economic self-sufficiency: }+0.3 \text { of a SD } \\
\text { for women only. } \\
\text { Adult health impacts of FSP are } \\
\text { minimal if child is exposed only after } \\
\text { age } 5 .\end{array}$ \\
\hline
\end{tabular}




\begin{tabular}{|c|c|c|c|c|}
\hline Study & Micro - Data, $\mathbf{N}$ & Identification strategy and specification & Effects of the shock & Heterogeneity \\
\hline \multicolumn{5}{|c|}{ Panel A: Policies to Increase Material Household Resources } \\
\hline $\begin{array}{l}\text { Gould, Lavy, and } \\
\text { Paserman (2011). } \\
\text { Effects of material } \\
\text { resources such as } \\
\text { running water, } \\
\text { electricity, and } \\
\text { sanitation during } \\
\text { childhood on } \\
\text { outcomes at age } \\
56-61 \text { of Yemenite } \\
\text { immigrants to } \\
\text { Isreal. }\end{array}$ & $\begin{array}{l}\text { 1) Authors conducted a survey in } 2006 \text { of } \\
\text { the entire population of immigrants who } \\
\text { were born in Yemen between } 1945 \text { and } \\
1950 \text { and arrived in Israel during } 1949 \\
\text { and } 1950 \text {. } \\
N=2,927 \text { individuals who were sorted } \\
\text { into } 233 \text { different locations. } \\
\text { 2) Census data for } 1961 \text {. }\end{array}$ & $\begin{array}{l}\text { Authors exploit quasi-random variation in the } \\
\text { living conditions experienced by Yemenite } \\
\text { children after being airlifted to Israel in } 1949 . \\
\text { Models regress a person's outcome on the } \\
\text { conditions experienced in childhood and on } \\
\text { family/indiv background. }\end{array}$ & $\begin{array}{l}\text { Running water, sanitation, and } \\
\text { electricity in early childhood - Results } \\
\text { for girls and women only: } \\
\text { HS matriculation: }+9 \mathrm{pp}(+33 \%) \text { (no SD } \\
\text { provided). Post-secondary: }+6 \mathrm{pp}(4.7 \%) \text {. } \\
\text { Years of schooling: }+0.6(5.3 \%) \text {. Age at } \\
\text { 1st marriage: }+0.6 \mathrm{pp}(2.7 \%) \text {. } \\
\text { Fertility (N_children): }-0.2 \mathrm{pp}(-5 \%) \text {. } \\
\text { Employed: }+7.2 \mathrm{pp}(11.3 \%) \text {. } \\
\text { Self-reported health problems: }-6.2 \mathrm{pp} \text { (- } \\
15.5 \%) \text {. No effect on disability. } \\
2 \text { nd generation effects in the full sample: } \\
\text { HS matriculation: } 3.2 \mathrm{pp} ; \\
\text { College degree: } 3.3 p p \text { (baseline means } \\
\text { not provided). }\end{array}$ & $\begin{array}{l}\text { By gender: } \\
\text { Effects are mainly for women which } \\
\text { could be due to: i) gender } \\
\text { discrimination in the allocation of } \\
\text { scarce resources or ii) a stricter } \\
\text { enforcement of traditional norms in } \\
\text { rural areas. } \\
\text { By age: } \\
\text { Authors include an interaction between } \\
\text { treatment variables and YOB \& find } \\
\text { that older women experience much } \\
\text { larger impacts (results not shown). }\end{array}$ \\
\hline $\begin{array}{l}\text { Lindo (2011). } \\
\text { Health effects of } \\
\text { parental job } \\
\text { displacement on } \\
\text { child's birth } \\
\text { weight. }\end{array}$ & $\begin{array}{l}\text { 1) PSID; waves: 1968- } 1997 \text { (author } \\
\text { stops in } 1997 \text { due to concerns in how job } \\
\text { displacement is measured). } \\
\text { Author uses the PSID's Childbirth \& } \\
\text { Adoption History Supp. (CAHS) to } \\
\text { measure children's outcomes i.e., birth } \\
\text { weight in ounces is available for children } \\
\text { born in } 1985+\text {; }=1,607 \text { births. }\end{array}$ & $\begin{array}{l}\text { Compare the outcomes of children born after a } \\
\text { displacement to the outcomes of those born } \\
\text { before. } \\
\text { Mother FE. } \\
\text { Models also include education-group trends and } \\
\text { industry trends. }\end{array}$ & $\begin{array}{l}\text { Child was born after his/her father's job } \\
\text { displacement: } \\
\text { Birth weight: }-4.8 \% \text { (approx. } 5 \text { ounces } \\
\text { decline). }\end{array}$ & $\begin{array}{l}\text { Mother's with }>\text { HS have higher percent } \\
\text { declines in family income, are more } \\
\text { likely to work, and to work for more } \\
\text { hours. } \\
\text { Potential mechanisms: Husbands' } \\
\text { earnings: -22\% } \\
\text { Family income: -13\%. Men's work } \\
\text { activity: no change. Mother's } \\
\text { employment status: no change. Food } \\
\text { spending: no change. }\end{array}$ \\
\hline
\end{tabular}




\begin{tabular}{|c|c|c|c|c|}
\hline Study & Micro - Data, N & Identification strategy and specification & Effects of the shock & Heterogeneity \\
\hline \multicolumn{5}{|c|}{ Panel A: Policies to Increase Material Household Resources } \\
\hline $\begin{array}{l}\text { Carlson (2015). } \\
\text { Examine the direct } \\
\text { consequences of } \\
\text { job loss on birth } \\
\text { outcomes, isolating } \\
\text { anticipatory } \\
\text { effects. }\end{array}$ & $\begin{array}{l}\text { 1) Dates of major job losses \& } \\
\text { information on the warnings given to the } \\
\text { local community using notices filed } \\
\text { under the Worker Adjustment \& } \\
\text { Retraining Notification (WARN) Act. } \\
\text { 2) Natality data, 1999-2008. } \\
\text { *The author constructs a county-month } \\
\text { panel data set including all } 422 \text { counties } \\
\text { in AL, NY, TX, \& WA; N=7,113,083 births } \\
\text { \& 2,626 WARN notices. }\end{array}$ & $\begin{array}{l}\text { Exploit county-month variation in the occurrence } \\
\text { of job losses through announced notices } \\
\text { Models include county-specific quadratic time } \\
\text { trends, county of birth, year of birth, \& calendar } \\
\text { month of birth FE. }\end{array}$ & $\begin{array}{l}\text { Being exposed to anticipatory } \\
\text { dislocations during pregnancy: } \\
\text { Birth weight: }-15 \text { to }-20 \text { grams ( }-0.4 \% \text { to }- \\
0.06 \%) \text {. } \\
\text { Gestational age: }-0.5 \text { to }-0.8 \text { days }(-0.2 \% \\
\text { to }-0.3 \%) \text {. } \\
\text { LBW }=+1 p p(+16.4 \%) \\
\text { Strongest effects are associated with } \\
\text { exposure to notices in } 3 \text { rd } \\
\text { trimester. }\end{array}$ & $\begin{array}{l}\text { Potential mechanisms: physiological } \\
\text { stress responses or increased levels of } \\
\text { - unhealthful behavior. }\end{array}$ \\
\hline $\begin{array}{l}\text { Golberstein, } \\
\text { Gonzales, and } \\
\text { Meara (2016). } \\
\text { Effects of } \\
\text { economic } \\
\text { recessions } \\
\text { (measured by UR } \\
\text { and HPI) on child } \\
\text { and adolescent } \\
\text { mental health. }\end{array}$ & $\begin{array}{l}\text { 1) National Health Interview Survey } \\
\text { (NHIS), years 2001-2013; nat. The child's } \\
\text { mental health questionnaire (SDQ score) } \\
\text { has } 5 \text { domains: emotional symptoms, } \\
\text { conduct pb's, hyperactivity-inattention, } \\
\text { peer problems, prosocial behaviour. } \\
\text { Mental health treatment \& medication } \\
\text { use are only available for 2005-2007. } \\
\text { 2) Economic variables are obtained from } \\
\text { the BLS \& from the Freddie Mac Housing } \\
\text { Price Index (HPI). }\end{array}$ & $\begin{array}{l}\text { Exploit the state and quarter variation in the } \\
\text { unemployment rate (UR). } \\
\text { Models include state \& quarter FE, individual and } \\
\text { family covariates, \& state linear time trends. }\end{array}$ & $\begin{array}{l}\text { A } 1 \text { SD increase in the UR: } \\
\text { SDQ score (index of mental health } \\
\text { severity; higher index, worse mental } \\
\text { health): }+2.3 \% \text { in the "mental health } \\
\text { severity } 1 / 10 \text { scale" and }+11 \% \text { in the } \\
\text { "likely psychological problem". } \\
\text { Emotional difficulty score: }+4.8 \% \text { in the } \\
\text { "mental health severity } 1 / 10 \text { scale" and } \\
+10.4 \% \text { in the "likely psychological } \\
\text { problem". } \\
\text { Use of special education services for } \\
\text { children's emotional problems: }+5.7 \% \text {. }\end{array}$ & $\begin{array}{l}\text { Parental unemployment, reduced } \\
\text { family income \& higher family stress } \\
\text { are likely to influence child mental } \\
\text { health. The impacts were stronger } \\
\text { among households where parents have } \\
\text { < college, are non-white, or are in the } \\
\text { bottom income quintiles. } \\
\text { Authors also find little differences by } \\
\text { child's gender or by child's age } \\
\text { (comparing children vs. adolescents). }\end{array}$ \\
\hline
\end{tabular}




\begin{tabular}{|c|c|c|c|c|}
\hline Study & Micro - Data, N & Identification strategy and specification & Effects of the shock & Heterogeneity \\
\hline \multicolumn{5}{|c|}{ Panel A: Policies to Increase Material Household Resources } \\
\hline $\begin{array}{l}\text { Gutierrez (2014). } \\
\text { Effect of birth } \\
\text { during economic } \\
\text { crisis in Peru on } \\
\text { infant mortality, } \\
\text { education and } \\
\text { employment at 15- } \\
18 \text { years. }\end{array}$ & $\begin{array}{l}\text { 1) National Household Survey (Encuesta } \\
\text { Nacional de Hogares, ENAHO), } 8 \text { waves: } \\
\text { 2004-2011; data on educational \& health } \\
\text { outcomes at later ages; } N=39,846 \\
\text { children. } \\
\text { 2) DHS data, } 3 \text { waves: } 1991,1996 \text { \& } \\
\text { 2000; data on mother's health \& child's } \\
\text { mortality; } N=11,275 \text { children. }\end{array}$ & $\begin{array}{l}\text { Estimate a two-sample instrumental variable } \\
\text { model: } \\
\text { 1) Regress child mortality in 1st year of life on } \\
\text { dummy for YOB interacted by mom's education. } \\
\text { 2) Regress outcome @age } 15 \text { on dummy for YOB } \\
\text { interacted by mom's education. } \\
\text { 3) Ratio of coefficients of interest in 1) \& 2) } \\
\text { shows the effect of early-life health shocks on } \\
\text { future outcomes. } \\
\text { Models include rich controls and some } \\
\text { specifications include trends. }\end{array}$ & $\begin{array}{l}\text { Exposure to the crisis and being born to } \\
\text { less educated mothers: } \\
\text { Prob(dying in the } 1 \text { st year of life): } 1 \% \text { (no } \\
\text { Table } 1 \text { available). } \\
\text { Chronic illness: }+2.36 p p \text { (no Table } 1 \\
\text { available). } \\
\text { Complete primary education (ages } 15- \\
\text { 18): -1.7pp. } \\
\text { Employment (ages } 15-18 \text { ): no effects. } \\
\text { Calculates upper and lower bounds on } \\
\text { the effects by assuming: i) there is no } \\
\text { selection; ii) there is no scarring effect. }\end{array}$ & $\begin{array}{l}\text { Mother's education: the increase in } \\
\text { infant mortality during the crisis was } \\
\text { particularly severe for children born to } \\
\text { less educated mothers. }\end{array}$ \\
\hline $\begin{array}{l}\text { Lavy, Schlosser, } \\
\text { and Shany (2016). } \\
\text { Children conceived } \\
\text { in Ethiopia and } \\
\text { born in Isreal after } \\
\text { their parents } \\
\text { migrated. Effects } \\
\text { of early childhood } \\
\text { conditions on } \\
\text { outcomes at 18-20. }\end{array}$ & $\begin{array}{l}\text { 1) High school administrative data linked } \\
\text { to demographic records for all Ethiopian } \\
\text { children born 1992-1992; data include } \\
\text { student's birth date, date of } \\
\text { immigration, country of origin of } \\
\text { students \& parents, student } \\
\text { demographics (parental education and } \\
\text { number of siblings), current schooling } \\
\text { status; data collected in 2007-2011; } \\
\mathrm{N}=1,951 \text { students. }\end{array}$ & $\begin{array}{l}\text { Exploit the timing of the immigration shock of } \\
\text { Ethiopian jews to Israel in the May } 1991 \text {. } \\
\text { DD: } \\
3 \text { groups by the gestational age at the time of } \\
\text { the immigration: } \\
\text { 1) Children whose mothers arrived after } \\
\text { conception but before week } 8 \text { of gestation. } \\
\text { 2) Children whose mothers arrived at } 8-24 \text { weeks } \\
\text { of gestation; } \\
\text { 3) Children whose mothers arrived after week } 25 \\
\text { of gestation but before birth. } \\
\text { Models include cohort \& month of birth FE and } \\
\text { rich controls. }\end{array}$ & $\begin{array}{l}\text { Exposure to Israel's better conditions } \\
\text { before week } 8 \text { of gestation: } \\
\text { Matriculation diploma: } 12.2 \% \text { ( } 0.07 \mathrm{SD}) \text {. } \\
\text { Quality of matriculation diploma (more } \\
\text { challenging study programs during high } \\
\text { school): }+33 \% \text { ( } 0.39 \mathrm{SD}) \text {. } \\
\text { Math credits: }+39.6 \%(0.32 \mathrm{SD}) \text {. } \\
\text { English credits: }+33 \% \text { ( } 0.37 \mathrm{SD}) \text {. } \\
\text { No effect on high school completion. } \\
\text { All efffects are driven by exposure in the } \\
\text { first } 8 \text { weeks of gestation (i.e., no effect } \\
\text { of exposure after week } 8) \text {. }\end{array}$ & $\begin{array}{l}\text { By gender: } \\
\text { Effects are only significant among girls. } \\
\text { By parental education: } \\
\text { Effects are stronger for children from } \\
\text { families with higher parental } \\
\text { education. (Though most immigrants } \\
\text { had low levels of education.) }\end{array}$ \\
\hline
\end{tabular}




\begin{tabular}{|c|c|c|c|c|}
\hline Study & Micro - Data, N & Identification strategy and specification & Effects of the shock & Heterogeneity \\
\hline \multicolumn{5}{|c|}{ Panel A: Policies to Increase Material Household Resources } \\
\hline $\begin{array}{l}\text { Loken, Mogstad, } \\
\text { and Wiswall } \\
\text { (2012). Effects of } \\
\text { Norwegian oil } \\
\text { boom on family } \\
\text { income and child } \\
\text { outcomes at } 29 \\
\text { plus. }\end{array}$ & $\begin{array}{l}\text { Administrative registers for the entire } \\
\text { population, provide information on } \\
\text { educational attainment, IQ, \& family } \\
\text { income during childhood, 1967-2006; } \\
\text { control variables: sex, birth year, marital } \\
\text { status, } N \text { of children, SES (years of } \\
\text { education, IQ, income, etc), personal } \\
\text { identifiers for one's parents, family } \\
\text { identifiers, geographic identifiers for } \\
\text { county of birth; } N=202,000 \text { children. }\end{array}$ & $\begin{array}{l}\text { 1) Show that the linear FE estimator identifies a } \\
\text { weighted average of the marginal causal effects. } \\
\text { 2) Use a Blinder-Oaxaca decomposition to } \\
\text { measure the contribution of different weights to } \\
\text { the differences between linear OLS, FE, \& IV } \\
\text { estimates. } \\
\text { IV: instrument for family income using the } \\
\text { regional \& time variation in the economic boom } \\
\text { after the oil discovery. } \\
\text { Also include sibling FE. }\end{array}$ & $\begin{array}{l}\text { A } 1 \text { SD increase in family income: } \\
\text { Years of Education - } \\
\text { Models without income squared: } \\
\text { No effects in IV or FE. } \\
\text { Models including income squared: } \\
\text { IV: }+0.74 \text { (child in poor family), }+0.05 \\
\text { (child in rich family). } \\
\text { FE: }+0.22 \text { (child in poor family), }+0.02 \\
\text { (child in rich family). }\end{array}$ & $\begin{array}{l}\text { Effects are larger in the lower part of } \\
\text { the income distribution. }\end{array}$ \\
\hline $\begin{array}{l}\text { Meckel (2015). } \\
\text { Examines the } \\
\text { effects of anti- } \\
\text { fraud efforts in the } \\
\text { WIC program } \\
\text { which resulted in } \\
\text { the shotdown of } \\
\text { some small } \\
\text { operators. }\end{array}$ & $\begin{array}{l}\text { 1) Administrative data about } \\
\text { WIC vendors in Texas. } \\
\text { 2) Prices from Nielsen Homescan data: } \\
\text { representative panel of consumers } \\
\text { w/product level-data on all purchases; } \\
\text { includes product type, date \& location of } \\
\text { purchase, \& on the purchaser; } \\
\mathrm{N}=430,000 \text { purchases ( } 11,400 \text { stores). } \\
\text { 3) Individual birth records that provides } \\
\text { informatio on WIC participation of } \\
\text { pregnant women and on ZIP code of } \\
\text { residence of the mother, 2005-09; N=1 } \\
\text { million mothers on WIC. }\end{array}$ & $\begin{array}{l}\text { Exploit the staggered county-level roll out of a } \\
\text { fraud reduction program in Texas through the } \\
\text { introduction of the Electronic Benefit Transfer } \\
\text { (EBT) that replaced paper vouchers. } \\
\text { DDD model: exploit variation in the exact timing } \\
\text { of EBT rollout across counties, years and months, } \\
\text { and WIC product and WIC store. } \\
\text { Assumption: the exact timing of EBT rollout is } \\
\text { uncorrelated with endogenous trends. }\end{array}$ & $\begin{array}{l}\text { The anti-fraud reform: } \\
\text { (1) Eliminated most pre-existing fraud } \\
\text { among stores (violations declined 15\%) } \\
\text { (2) Caused } 10-26 \% \text { of single outlets to } \\
\text { drop out of WIC (no change for chains) } \\
\text { (3) Reduced WIC participation among } \\
\text { eligible mothers by } 3-5 \% \\
\text { (4) Reduced the likelihood that a mother } \\
\text { has at least one WIC store in her ZIP } \\
\text { code (a fall of } 10-25 \% \text { ) } \\
\text { (5) Increased the prices on WIC products } \\
\text { within single outlet WIC stores by } 9 \% \\
\text { (6) Reduced welfare by 3-4\% of the } \\
\text { value of benefits received }\end{array}$ & $\begin{array}{l}\text { The largest declines in WIC } \\
\text { participation among stores and women } \\
\text { occur in high-poverty ZIP codes. } \\
\text { Only fraudulent stores select into the } \\
\text { program in high-poverty areas, } \\
\text { suggesting that fraud implicitly } \\
\text { subsidizes program access in these } \\
\text { areas. }\end{array}$ \\
\hline
\end{tabular}




\begin{tabular}{|c|c|c|c|c|}
\hline Study & Micro - Data, N & Identification strategy and specification & Effects of the shock & Heterogeneity \\
\hline \multicolumn{5}{|c|}{ Panel A: Policies to Increase Material Household Resources } \\
\hline $\begin{array}{l}\text { Milligan and } \\
\text { Stabile (2011). } \\
\text { Effects of child } \\
\text { benefit payments } \\
\text { in Canada on child } \\
\text { outcomes from 0- } \\
10 .\end{array}$ & $\begin{array}{l}\text { 1) National Longitudinal Survey of } \\
\text { Children and Youth (NLSCY), provides } \\
\text { family income \& demographics; } 6 \\
\text { biannual cycles: } 1994-95 \text { to } 2004-05 ; \\
\text { followed children aged 0-11 to age 10- } \\
21 ; \mathrm{N}=108,000 \text { children. } \\
\text { 2) Survey of Labour \& Income Dynamics } \\
\text { (SLID) used to simulate the aggregate } \\
\text { benefits (instruments). }\end{array}$ & $\begin{array}{l}\text { Exploit the variation in child benefits across } \\
\text { province, year, and family-type ( } \mathrm{N} \text { of children in } \\
\text { a household) due to changes in legislation. } \\
\text { Instrument: actual child benefit level in a given } \\
\text { year, province,, family size is instrumented with } \\
\text { a simulated tax benefit computed using a tax \& } \\
\text { benefit calculator. } \\
\text { Models include a set of individual/ family } \\
\text { characteristics, and control variables for time } \\
\text { and province effects. }\end{array}$ & $\begin{array}{l}\text { An increase of } \$ 1,000 \text { in child benefits: } \\
\text { Education: Repeating a school grade: no } \\
\text { effect; Math score: }+0.069 \text { SD }(+1.6 \%) ; \\
\text { PPVT: no effect } \\
\text { Prob (not been diagnosed with a } \\
\text { learning disability): }+2.8 \mathrm{pp}(+1.0 \%=0.16 \\
\text { SD) } \\
\text { Emotional/behavioral well-being: } \\
\text { Physical aggression: }-0.106 \text { SD }(-14 \%)\end{array}$ & $\begin{array}{l}\text { Most significant effects are driven by } \\
\text { boys, not girls. For girls, there is a } \\
\text { significant effect on physical aggression } \\
\text { (-.14 SD for boys; -.22 SD for girls). }\end{array}$ \\
\hline $\begin{array}{l}\text { Scholte, van den } \\
\text { Berg, and } \\
\text { Lindeboom (2015). } \\
\text { Influence of } \\
\text { economic } \\
\text { conditions early in } \\
\text { life on the impact } \\
\text { of adverse life } \\
\text { events and on } \\
\text { physical health } \\
\text { later in life. }\end{array}$ & $\begin{array}{l}\text { 1) Longitudinal Aging Study Amsterdam } \\
\text { (LASA); } 5 \text { waves: 1992-1993, 1995-1996, } \\
\text { 1998-1999, 2001-2002, 2005-2006, } \\
\text { (N=2869, 2001, 1571, 1132, 799 } \\
\text { persons). } \\
\text { Data includes info on: functional } \\
\text { limitations, heart disease, stroke, cancer, } \\
\text { respiratory diseases, peripheral artery } \\
\text { disease, diabetes and arthritis. }\end{array}$ & $\begin{array}{l}\text { Ask how shocks in later life affect functional } \\
\text { limitations in later life AND whether individuals } \\
\text { exposed to recessions early in life respond } \\
\text { differently to later-life shocks than other adults. } \\
\text { Strategy: IV + individual FE. Instrument: Business } \\
\text { cycle at birth (boom or recession). } \\
\text { Regressions include interactions btw: (indicator } \\
\text { for a recession at birth) * (adverse later life } \\
\text { events). }\end{array}$ & $\begin{array}{l}N \text { of functional limitations later in life: } \\
\text { Chronic disease: }+8.6 \% \\
\text { (Chronic disease)*(early-life recessions): } \\
+10.5 \% \\
\text { This result indicates that the effects of } \\
\text { chronic diseases on functional } \\
\text { limitations are exacerbated by adverse } \\
\text { early-life conditions }\end{array}$ & $\begin{array}{l}\text { Effects of chronic disease and (Chronic } \\
\text { disease)*(early-life recessions) are only } \\
\text { positive \& significant among males. }\end{array}$ \\
\hline
\end{tabular}




\begin{tabular}{|c|c|c|c|c|}
\hline Study & Micro - Data, N & Identification strategy and specification & Effects of the shock & Heterogeneity \\
\hline \multicolumn{5}{|c|}{ Panel A: Policies to Increase Material Household Resources } \\
\hline $\begin{array}{l}\text { Rossin-Slater } \\
\text { (2013a). Effect of } \\
\text { closures of WIC } \\
\text { clinics in Texas on } \\
\text { birth outcomes. } \\
\end{array}$ & $\begin{array}{l}\text { 1) Texas Birth \& admin. records } \\
\text { 2005-2009; data includes mothers' } \\
\text { maiden name, DOB, counties of birth, } \\
\text { ZIP codes of residence; allows linking of } \\
\text { siblings \& determining whether mothers } \\
\text { had an operating WIC clinic in their ZIP } \\
\text { code during pregnancy; } N=1,937,003 \\
\text { births ( } 612,694 \text { siblings). } \\
\text { 2) WIC clinic locations come from TX } \\
\text { Dept. of State Health Services; includes } \\
\text { names, address/ZIP codes, \& opening/ } \\
\text { closing dates in } 2005 \text {-2010 ( } N=578 \text { ZIP } \\
\text { codes; } 114 \text { experienced openings/ } \\
\text { closures). }\end{array}$ & $\begin{array}{l}\text { Exploit the within-ZIP-code variation in WIC clinic } \\
\text { openings/closings. Compare births by mothers } \\
\text { who did \& did not have a WIC clinic in their ZIP } \\
\text { code during pregnancy \& control for mother-FE } \\
\text { with IV (to account for migration, measurement } \\
\text { error, \& the mechanical correlation between } \\
\text { gestation \& WIC participation (instrument: } \\
\text { dummy for whether mother would have had an } \\
\text { open WIC clinic during her current pregnancy in } \\
\text { the ZIP code of her 1st pregnancy assuming } 39 \\
\text { weeks gestation). Models include individual } \\
\text { controls, YOB \& MOB FE, ZIP code-FE, county } \\
\text { linear time trends. }\end{array}$ & $\begin{array}{l}\text { The presence of a WIC clinic in a } \\
\text { mother's ZIP code of residence, during } \\
\text { her pregnancy: } \\
\text { Food benefit take-up: }+6 \% \\
\text { Pregnancy weight gain: too little weight } \\
(<7.3 \mathrm{~kg}):-2 \mathrm{pp} \text {; too much weight ( }>18 \\
\mathrm{~kg}):+3 \mathrm{pp} \text { (among those with }<=\mathrm{HS} \text { educ) } \\
\text { Diabetes: }+1.3 \mathrm{pp} \text { (among those with } \\
<=\mathrm{HS} \text { educ) } \\
\text { Gestational hypertension: }+1.3 \mathrm{pp} \\
\text { (among those with }<=\mathrm{HS} \text { educ) } \\
\text { Birth weight: }+27 \mathrm{gr}(+0.8 \%) \text { (full sample) }\end{array}$ & $\begin{array}{l}\text { Strongest effects for mothers with high } \\
\text { school or less, who are most likely } \\
\text { eligible for WIC services ( } 0.74 \% \text { WIC } \\
\text { take-up vs. } 0.07 \% \text { among other moms). } \\
\text { The increase in BW is concentrated in } \\
\text { the middle of the BW distribution. }\end{array}$ \\
\hline $\begin{array}{l}\text { Rossin-Slater } \\
\text { (2013b). How did } \\
\text { changes in } \\
\text { paternity } \\
\text { establishment laws } \\
\text { affect young } \\
\text { children's access to } \\
\text { resources and } \\
\text { health outcomes in } \\
\text { the U.S.? }\end{array}$ & $\begin{array}{l}\text { 1) Paternity establishments in hospital, } \\
\mathrm{N}=601 \text { state-year obs. } \\
\text { 2) CPS-CSS \& March CPS, 1994-2008 } \\
\text { child support supplements (CSS); } \\
\mathrm{N}=8,974 \text { who respond to CSS); } \\
\text { 3) NHIS data } 1997-2010 \text { restricted } \\
\text { sample of child files; provides info on } \\
\text { child mental \& physical health. } \\
\text { 4) Fragile Families \& Child Well-Being } \\
\text { Study. }\end{array}$ & $\begin{array}{l}\text { Exploit variation in the timing of in hospital } \\
\text { paternity establishment across states. } \\
\text { Models regress a child outcome on the in } \\
\text { hospital paternity establishment dummy, rich } \\
\text { individual controls, state \& child birth year FE, \& } \\
\text { state-specific time trends. } \\
\text { Author imputes birth year = survey year - child } \\
\text { age - } 1 \text { since interview year are in March. }\end{array}$ & $\begin{array}{l}\text { Paternity establishment no effects on } \\
\text { time spent father \& child. } \\
\text { Child private health insurance: }-2.65 p p \text { (- } \\
3.89 \%) \text {. } \\
\text { Child physical health (asthma, ear } \\
\text { infection): no effects. } \\
\text { Any well-visits: }-1.99 p p(-2.53 \%) \text {. Any } \\
\text { doctor visits: }-1.48 p p(-1.78 \%) . \text { Child } \\
\text { mental health: no effects. } \\
\text { Income, poverty status, or welfare } \\
\text { benefit receipt: no effects. }\end{array}$ & No differences by mother's race. \\
\hline
\end{tabular}


Table 3: Two-Shock Studies

\begin{tabular}{|c|c|c|c|c|}
\hline Study & Micro - Data, N & Identification strategy and specification & Effects of the shock & $\begin{array}{c}\text { Heterogeneity in } \\
\text { mechanisms/effects }\end{array}$ \\
\hline $\begin{array}{l}\text { varyu, } \\
\text { ina, } \\
\text { hadham, and } \\
\text { layo (2015). } \\
\text { mine the }\end{array}$ & $\begin{array}{l}\text { 1) Baseline and follow-up surveys } \\
\text { of HHs in Progresa; 1997, follow- } \\
\text { ups every } 6 \text { months for the first } 3 \\
\text { years of the program (1998 to } \\
2000 \text { ). }\end{array}$ & $\begin{array}{l}\text { Exploit two orthogonal sources of exogenous } \\
\text { variation: 1) Parents' resources at the time of a } \\
\text { child's year of birth \& state of residence (proxied } \\
\text { by local rainfall) \& } 2 \text { ) The returns to investing in } \\
\text { education during adolescence (via the RCT }\end{array}$ & $\begin{array}{l}\text { Exposure to adverse rainfall in the YOB: } \\
\text { Years of educ: }-0.57 \text {. } \\
\text { Mitigating impact of Progresa: }+0.1 \mathrm{yrs} \\
\text { for each year in the program. On } \\
\text { average, }\end{array}$ & $\begin{array}{l}\text { Effects of Progresa are } \\
\text { larger for children with } \\
\text { lower endowments (i.e., } \\
\text { those who were affected } \\
\text { by the rainfall shock). }\end{array}$ \\
\hline
\end{tabular}

effect of a $\quad$ 2) ENCEL 2003; a HH survey of the program Progresa).

conditional cash 506 localities that were part of Model includes dummy for rainfall shock, Progresa

transfer program the original evaluation. exposure, the interaction btw rainfall shock and

on the impacts 3) Mexico's National Progresa, state FE, birth year FE, \& rich controls.

Progresa mitigated $60-80 \%$ of the effect

of rainfall shocks Meteorological Service provides

in Mexico. rainfall data, 1975-2003.

Outcomes Data were matched using GPS

measured at 12 coordinates, $\mathrm{N}=14,464$.

to 21 years.

Woodcock-Munoz tests (letter-word

identification, applied problems, \&

dictation): -0.22 to -0.25 SD.

\begin{tabular}{|c|c|c|c|c|}
\hline $\begin{array}{l}\text { Aguilar and } \\
\text { Vicarelli (2015). } \\
\text { Exposure to } \\
\text { extreme } \\
\text { precipitation in } \\
\text { Mexico due to El } \\
\text { Nino and } \\
\text { outcomes at age } \\
2-6 .\end{array}$ & $\begin{array}{l}\text { 1) } 3 \text { waves of longitudinal } \\
\text { household data from Mexico's } \\
\text { Progresa conditional cash transfer } \\
\text { program: } 1997,2000,2003 ; \\
\mathrm{N}=6,264 \text { children. Data NOT } \\
\text { nationally representative. }\end{array}$ & $\begin{array}{l}\text { 1) DD model: Compare children in villages that } \\
\text { experienced rainfall shocks vs. children in regions } \\
\text { that did not. } \\
\text { Model includes individual controls + village and } \\
\text { year of child's birth FE. } 2 \text { ) Mitigating impacts of } \\
\text { Progresa: Use random selection of villages into } \\
\text { Progresa to estimate the effect of early vs late ( } 2 \\
\text { yrs difference) allocation to treatment. Use the } \\
\text { administrative selection rule for Progresa } \\
\text { recepients to estimate an RD. }\end{array}$ & $\begin{array}{l}\text { Exposure to El Nino: Height: }-0.43 \text { to - } \\
0.71 \text { inches ( }-2 \%=-0.2 \text { SD). } \\
\text { Stunting: }+13 p p(0.3 \text { SD). Weight: }-0.84 \\
\text { pounds }(-2.5 \%=-0.13 \text { SD). } \\
\text { PPVT=-15\% }(-0.34 \text { SD). Working } \\
\text { memory= }-18 \%(-0.44 \text { SD). } \\
\text { Visual-spatial thinking= }-13 \% \text { (-0.5 SD). } \\
\text { Gross motor skills: no effects. Effects } \\
\text { were not mitigated by Progresa. }\end{array}$ & $\begin{array}{l}\text { 1) Effects were more } \\
\text { pronounced for children } \\
\text { affected in the 1st two } \\
\text { years of life versus prior to } \\
\text { birth: } \\
\text { Height: }-0.71 \text { inches vs. - } \\
0.56 \text { inches. PPVT=-21\% } \\
\text { vs. }-15 \% \text {. Working } \\
\text { memory= -19\% vs. }-15 \% \text {. } \\
\text { Visual-spatial thinking=- } \\
13 \% \text { vs. }-12 \% \text {. }\end{array}$ \\
\hline
\end{tabular}

1) 3 waves of longitudinal

model: Compare children in villages that

that did not.

Progresa to estimate the effect of early vs late $(2$

recepients to estimate an $\mathrm{RD}$. 


\begin{tabular}{|c|c|c|c|c|}
\hline Study & Micro - Data, N & Identification strategy and specification & Effects of the shock & $\begin{array}{c}\text { Heterogeneity in } \\
\text { mechanisms/effects }\end{array}$ \\
\hline $\begin{array}{l}\text { teinsson, } \\
\text { ryu, } \\
\text { ian et al. } \\
\text {. Effect of } \\
\text { onal } \\
\text { ments in } \\
\text { desh in } \\
\text { ting the } \\
\text { s of }\end{array}$ & $\begin{array}{l}\text { 1) RCT took place in } 2001-2007 \text {, } \\
\mathrm{N}=18,767 \text { infants, } 41 \text { sectors ( } 20 \\
\text { received supplements, } 20 \\
\text { placebo). } \\
\text { 2) Survey on the effects of the } \\
\text { tornado } 2005 \text {; collected data on } \\
\text { damages, deaths (the tornado } \\
\text { affected } 17 \text { of the } 41 \text { sectors). }\end{array}$ & $\begin{array}{l}\text { Exploit data from an RCT of a nutritional } \\
\text { supplementation program for newborns \& } \\
\text { mothers. A tornado occured on March 20th, } 2005 . \\
\text { Authors exploit 3-sources of variation: 1) RCT of } \\
\text { vitamin A suppl.; 2) spatial variation in tornado } \\
\text { exposure; 3) variation in trimester of pregnancy } \\
\text { exposed to tornado. } \\
\text { DDD: compare babies born at different times } \\
\text { (within \& outside of a window around the }\end{array}$ & $\begin{array}{l}\text { Tornado exposure in early pregnancy: } \\
\text { BW: }-14 \mathrm{pp}(-0.6 \%=-0.03 \text { of a SD). } \\
\text { Height: }-0.54 \mathrm{~cm}(-1.2 \%=-0.23 \text { of a SD). } \\
\text { Mid-upper arm circumference: }-0.29 \mathrm{~cm} \\
(-0.31 \%=-0.35 \text { of a SD.) } \\
\text { Head circumfernce (HC): }-0.54 \mathrm{~cm}(-1.7 \% \\
=0.33 \text { of a SD). } \\
\text { Chest circumference (CC): }-0.34 \mathrm{~cm}(- \\
1.1 \%=-0.16 \text { of a SD). }\end{array}$ & $\begin{array}{l}\text { Those treated with vitamin } \\
\text { A at birth through the RCT } \\
\text { were effectively protected } \\
\text { from the shock in terms of } \\
\text { antropometric outcomes at } \\
6 \text { months. There was little } \\
\text { protective effect of } \\
\text { maternal supplementation } \\
\text { during pregnancy. }\end{array}$ \\
\hline
\end{tabular}

tornados on tornado), across sectors affected by \& unaffected

infants. by the tornado.

\begin{tabular}{|c|c|c|}
\hline $\begin{array}{l}\text { Rossin Slater and } \\
\text { Wust (2015). } \\
\text { Explore main } \\
\text { effects and } \\
\text { interactions } \\
\text { between high } \\
\text { quality preschool } \\
\text { childcare and a } \\
\text { nurse home } \\
\text { visiting program. } \\
\text { Examine effects } \\
\text { on children and } \\
\text { children's } \\
\text { children. }\end{array}$ & $\begin{array}{l}\text { 1) Digital Atlas of the Danish } \\
\text { Historical \& Admin. Geography: } \\
\text { includes individual \& municipal- } \\
\text { level data; source of outcomes } \\
\text { data for } 2 \text { nd generation. } \\
\text { 2) Historical data on state- } \\
\text { regulated CC centers: address, } \\
\text { year established, number of } \\
\text { children (collapsed to } \\
\text { municipality* year*gender cells) } \\
\text { (N=3,600 cells). } \\
\text { 3) Nurse Home Visiting Program } \\
\text { (NHV): Date program approval for } \\
\text { all minicipalities over 1937-1949 } \\
\text { from the Danish National } \\
\text { Archives. } \\
\text { 4) Inpatient records, 1994-2010. } \\
\mathrm{N}=869,273 \text { observations. }\end{array}$ & $\begin{array}{l}\text { DD model: Exploit the municipality*year variation } \\
\text { in CC center approvals \& in the NHV program } \\
\text { rollout. } \\
\text { Identifying assumptions: (1) the timing of approvals } \\
\text { is uncorrelated w/other municipal time-varying } \\
\text { characteristics that also predict outcomes; (2) the } \\
\text { timing of approvals is uncorrelated with the NHV } \\
\text { program rollout. }\end{array}$ \\
\hline
\end{tabular}
LT impacts of the CC program:
Years of schooling: $+2 \%$
Only compulsory education: $-11 \%$
Labor mkt: $+1.6 \%$ wages (males)
Mortality: $-10 \%$ (females).
Intergenerational effects of CC:
Years of schooling (@age 25): +0.4\%

\author{
Interaction effects on \\ education and on income \\ were mostly driven by \\ males (even persistent on \\ the second generation), \\ while effects on mortality
} were larger for females.

Only compulsory educ @age 25: -6\%.

But interactions of CC and NHV

program and negative, suggesting substitution:

Most positive effects of child care

reduced by $80 \%$ suggesting that

subsidized child care much less effective

when NHV is already in place. 


\section{Panel B: Maternity Leave Policy}

Baker and Milligan 1) National Longitudinal Survey of Children (2015). Expansion of and Youth (NLSCY), 1994/5 to 2008/09. paid maternity leave $\mathrm{N} \sim 10,000$ obs.

in Canada on children's outcomes after the reform so that any age effects at age 4-5. average out.

2) Labour Force Survey (LFS) that includes data on labor force status.
Exploit the variation in time at home post-birth induced by A 1month increase in maternal care the maternity leave reform extending maximum length of paid leave from 25 to 50 weeks.

was born after the law change (i.e., December 31, 2000). Models include time trends \& rich individual controls. test": $-5.1 \%$ of a SD

Behavioral outcomes (hyperactivity anxiety, physical aggression, \& indirect aggression): no effect
By child's gender: negative \& significant effects only for boys. By mother's educ (HS or less vs. >HS) effects seem to be only negative \& significant for children of more educated mothers.

\begin{tabular}{l} 
Carneiro, Loken, \& \\
Salvanes (2013). \\
Effect of an \\
unexpected \\
extension of paid \\
maternity leave in \\
Norway on the \\
education and wages \\
of children at age 30. \\
\\
\hline Dahl, Loken, \\
Mogstad, and \\
Salvanes, (2013). \\
Effect of an \\
unexpected change \\
in paid maternity \\
leave in Norway on \\
parental earning, \\
fertility, LFP and \\
child test scores.
\end{tabular}

Norwegian Registry data: covering the

population of Norwegians up to 2007 and a 1 1) RD: comparing children of eligible mothers born just providing month and year of birth,

education, labour market status, age, gender, data on families. with parents. $\mathrm{N} \sim 42,600$ obs.

\section{1) Social security registers, 1992-onwards.} Multiple years merged using individual identifiers.

Authors do not observe actual eligibility, therefore, predict eligibility using labor earnings the year before birth. $\mathrm{N}=21,838$.

Two strategies: before and just after July 1, 1977 when maternity leave to 12 months unpaid.

2) DD: Treatment: Difference between mothers who had child in June and those who had a child in July 1977. Control: Difference between mothers who had a child in June and those who had a child in July of 1975, 1977, and 1978.

RD: exploit the discontinuity from the reform being

Children of mothers who benefited from

PAID maternity leave:

HS drop-out (refers to a 3 yr HS diploma): -

$2 p p(-7 \%=-0.04$ SD)

Ever started college (at age 30$):+2 p p(+5 \%$

Wages (at age 30 ): $+5 \%$ to $+6.2 \%$. contingent on the birthdate of the child. A series of reforms 1) Did not crowd out unpaid leave extended paid maternity leave from 18 weeks to 35 weeks. 2) Effects on individual outcomes: Authors exploit this type of variation from 6 different maternity leave reforms in Norway.

Since take-up is very high ITT ATE.

Models include time trends \& rich individual controls; also include quadratic trends on each side of the discontinuity.

No effects on test scores, school drop-out, parental earnings, mother's LFP after birth (rate of returning to work two years after the birth), completed fertility, marriage or divorce: no effects.

3) Cost-benefit analysis "Paid maternity leave is regressive."
Danzer and Lavy

(2016). Effect of a Austrian maternity

leave reform extending leave 12 to 24 months on school programme, location, school size, resources); Not included: DOB, maternal labour market participation at the time of birth, duration of leave taking of mothers. $\mathrm{N}=764$.

1) OECD's PISA data, 2003 \& 2006; includes student-reported background information (e.g., gender, birth year, month nationality, attitudes), parents (education 1) RD

\section{2) $D D$ - RD}

Treatment group: children born after July 1st 1990 and before December 31st 1990.

Control group: children born in the 1st half of 1990 ( $\&$ in 1987).

Models include rich mother controls \& month of chld's birth

FE. Estimates are ITT since actual leave taking is not

observed.

\section{No effects on PISA test scores in the full} sample.

came in effect on July 1, 1990 which extended paid leave

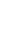




\section{Leave Policy}

Rossin-Slater (2011). 1) Vital Statistics natality \& mortality 1989Effects of extensions 1997 collapsed into birth-year/birth-

of unpaid maternity month/county/mother-education/mother-

leave on birth race/mother-age/ mother marital-status cells; $\mathrm{N}=5,806,669$ cells. states $\&$ variation in which firms are covered by FMLA

outcomes and

provisions.

fertility in the U.S.

Business Patterns (CBP), 19891997, to estimate the likelihood that a resident of a county is employed in a firm with 50 or $>$ employees/year.

3) Quarterly Workforce Indicators (QWI) to check the firm-size procedure.

4) 1990 Census by county of birth to construct county-level controls.

Link datasets by county $\&$ year ( $>98 \%$ of

cases matched)

\& after FMLA, \& across states.
By mother's education \& marital status:

Married college mothers VS. single

mothers with out college:

BW: $+9.2 \mathrm{gr}(+0.3 \%=+0.02 \mathrm{SD})$ vs. $7.1 \mathrm{gr}$ $(0.2 \%=0.016 \mathrm{SD})$.

Compare the likely eligible \& likely ineligible groups before Prob(preterm): $-3 \%$ (0.1 SD)

Gestation length: $+0.04 \%(0.008 \mathrm{SD})$

LBW: $-0.2 \%(0.01 \mathrm{SD})$

Infant mortality: $-2.5 \%$ (-0.017 SD).

Gestation length: $+0.06 \%(0.012 \mathrm{SD})$ vs no effect.

LBW: $-0.2 \%$ (0.01 SD) vs. $-0.3 \%(0.012$ SD)

Models control for rich county-level \& mother controls, Overall fertility: no effects.

month-of-birth, year-of-birth, state FE, state specific time Parity at birth: increase in first-parity birth
trend.

Estimates are ITT given that author does not observe leave- encouraged some previously childless effect.

nfant mortality: $-10 \%$ vs. no effect. Changes in parity at birth driven by single, less than college mothers. 


\begin{tabular}{|c|c|c|c|c|}
\hline Study & Micro - Data, N & Identification strategy and specification & Effects of the shock & $\begin{array}{c}\text { Heterogeneity in } \\
\text { mechanisms/effects }\end{array}$ \\
\hline \multicolumn{5}{|c|}{ Panel C: Child Care } \\
\hline $\begin{array}{l}\text { Aizer and Cunha } \\
\text { (2014). Head } \\
\text { Start effects on } \\
\text { outcomes } \\
\text { measured at age } \\
7 .\end{array}$ & $\begin{array}{l}\text { National Collaborative Perinatal } \\
\text { Project (NCPP); children \& parents } \\
\text { were followed before birth up to } \\
\text { age } 7 \text {; waves: } 8 \text { mths, 1, } 4,7 \text { years } \\
\text { after birth; years of birth: } 1959- \\
\text { 1965, } 12 \text { cities. } N=10,157 \text { obs. } \\
\text { Sample includes } 8 \text {-mth Bayley } \\
\text { score; authors argue that the Bayley } \\
\text { is more predictive of later human } \\
\text { capital than birth weight. }\end{array}$ & $\begin{array}{l}\text { Exploit the introduction of Head Start in } 1966 \\
\text { in a model with sibling FE. } \\
\text { Older siblings had no acces to HS. } \\
\text { Focus on the ability of initial endowments to } \\
\text { predict parental investments at age } 8 \text { months } \\
\text { \& at age } 7 \text {. } \\
\text { Regression models include an interaction } \\
\text { between HS_enrollment*Investments_8mths } \\
\text { and controls for HS_enrollment, investments } \\
\text { at } 8 \text { mths, individual covariates, \& family-FE. }\end{array}$ & $\begin{array}{l}\text { The effect of HS* Bayley score at 8mths (Sibling-FE): } \\
\text { Child IQ (age 4): } 16.5 \% \text { SD. } \\
\text { Cogn. Achievement age } 7 \text { (ONLY signi. for those } \\
\text { w/high initial HK): } \\
\text { IQ: } 10.4 \% \text { SD. Reading: no effect. Math score: } 16.0 \% \\
\text { SD. } \\
\text { Parents invest more in highly endowed children. } \\
\text { Preschool invest. \& early HK are complements in } \\
\text { the prod. of late HK. } \\
\text { Degree of reinforcement increases w/family size. }\end{array}$ & $\begin{array}{l}\text { The impact of HS is largest for } \\
\text { those w/higher early } \\
\text { cognitive development at age } \\
8 \text { mths. } \\
\text { By age } 7 \text {, the effect of HS on } \\
\text { IQ \& achievement have faded } \\
\text { except for those with the } \\
\text { highest endowments. }\end{array}$ \\
\hline $\begin{array}{l}\text { Attanasio, Di } \\
\text { Maro, and Vera- } \\
\text { Hernandez } \\
\text { (2013). Impact } \\
\text { of a preschool } \\
\text { program in } \\
\text { Colombia } \\
\text { (Hogares } \\
\text { Comunitarios, } \\
\text { HC) on children's } \\
\text { nutrition at age } 2 \\
6 .\end{array}$ & $\begin{array}{l}\text { 1) Survey of Familias en Accion } \\
\text { (conditional cash transfer program } \\
\text { in Colombia): representative of } \\
\text { poor individuals in rural areas; focus } \\
\text { on } 65 \text { towns where preschool } \\
\text { program was not implemented; } \\
\text { years } 2002,2003 \text {, \& 2005-6; } \\
\mathrm{N}=2,413 \text { children. } \\
\text { 2) ENDS: a more complete version } \\
\text { of the DHS 2005; basic household } \\
\text { demographics, children } \\
\text { anthropometrics \& participation in } \\
\text { HC; urban areas, includes poor and } \\
\text { less poor; } \mathrm{N}=6,179 \text { children. }\end{array}$ & $\begin{array}{l}\text { To address the endogeneity of } \mathrm{HC} \\
\text { participation authors instrument using: } \\
\text { i) distance from the residence to the nearest } \\
\text { nursery, } \\
\text { ii) the median fee in the town, } \\
\text { iii) the capacity of the } \mathrm{HC} \text { programme in the } \\
\text { town (filled + vacant } \mathrm{HC} \text { slots / } \mathrm{N} \text { of eligible } \\
\text { children in the town). } \\
\text { Model covariates include the } \mathrm{N} \text { of children } \\
\text { aged 2-6 in the town, the distance to other } \\
\text { amenities (school, health centre and town } \\
\text { hall), mother \& head's ages \& education } \\
\text { levels and mother's height, as well as town- } \\
\text { level variables. }\end{array}$ & $\begin{array}{l}\text { Exposure to HC: } \\
\text { Height-for-age: }+0.88 \mathrm{SD} \text { (FeA sample); +1.23 SD } \\
\text { (ENDS sample). } \\
\text { Atendance to HC: } \\
\text { Height-for-age: }+0.4 \mathrm{SD} \text { (FeA sample); +0.83 SD } \\
\text { (ENDS sample). } \\
\text { "A } 60 \text {-month-old child that has spent } 24 \text { months in } \\
\text { an HC would be } 0.35 \text { SD (FeA) or } 0.49 \text { SD (ENDS) } \\
\text { taller." }\end{array}$ & $\begin{array}{l}\text { The impact of the programme } \\
\text { is considerably higher for } \\
\text { lower quantiles \& almost zero } \\
\text { for the top quantiles. }\end{array}$ \\
\hline
\end{tabular}




\begin{tabular}{|c|c|c|c|c|}
\hline Study & Micro - Data, N & Identification strategy and specification & Effects of the shock & $\begin{array}{c}\text { Heterogeneity in } \\
\text { mechanisms/effects }\end{array}$ \\
\hline \multicolumn{5}{|c|}{ Panel C: Child Care } \\
\hline $\begin{array}{l}\text { Attanasio, } \\
\text { Fernandez, } \\
\text { Fitzsimons et al. } \\
\text { (2014). Effects } \\
\text { of a psychosocial } \\
\text { and nutritional } \\
\text { intervention in } \\
\text { Colombia on } \\
\text { outcomes at } 12- \\
24 \text { months. }\end{array}$ & $\begin{array}{l}\text { Baseline was collected in Feb-May } \\
2010 \text { \& follow-up in Sept-Dec 2011; } \\
\text { duration of the program was } 18 \\
\text { months. Data collection includes } \\
\text { rich measures of child cognitive } \\
\text { tests \& physical health, HH } \\
\text { characteristics, at ages } 1-2 . \\
N=1,420 \text { children in } 96 \\
\text { muncipalities (out of the } 1,100 \text { in } \\
\text { Colombia). } \\
\text { Sample sizes: Control ( } n=318) \\
\text { Stimulation ( } n=318) \\
\text { Supplementation }(n=308) \text { Both } \\
\text { interventions }(n=319) \text {. }\end{array}$ & $\begin{array}{l}\text { RCT in } 96 \text { towns in Colombia using a } 2 \times 2 \\
\text { factorial design } \\
\text { There were } 4 \text { interventions: } \\
\text { i) psychosocial stimulation alone ( } n=318) \text {, } \\
\text { ii) micronutrient supp. alone ( } n=308) \text {, iii) both } \\
\text { combined ( } n=319 \text { ), iv) control ( } n=318) \text {. } \\
\text { Models include tester effects (two for each } \\
\text { region), baseline level of the outcomes, sex, } \\
\text { and a second order polynomial in age. }\end{array}$ & $\begin{array}{l}\text { Psychological stimulation: } \\
\text { Cognitive scores (Bayley-III): }+0.26 \text { SD (3.7\%) } \\
\text { Receptive language: }+0.22 \text { SD }(5.4 \%) \\
\text { No effects on expressive language, fine motor skills, } \\
\text { height, weight, hemoglobin. } \\
\text { Micronutrient supplementation had no effect on } \\
\text { any outcomes. } \\
\text { Interactions between psychosocial \& nutritional } \\
\text { interventions had no effects on any outcomes. }\end{array}$ & NA \\
\hline $\begin{array}{l}\text { Baker, Gruber, } \\
\text { and Milligan } \\
\text { (2015). What are } \\
\text { the long-run } \\
\text { impacts of } \\
\text { interventions } \\
\text { that foster a } \\
\text { deterioration in } \\
\text { non-cognitive } \\
\text { skills? }\end{array}$ & $\begin{array}{l}\text { 1) Canadian National Longitudinal } \\
\text { Study of Children and Youth; } \\
\text { biannual btw 1994-951 \& 2008-09; } \\
\text { focus on children 0-9; N 2,000 obs. } \\
\text { 2) Test Scores: School Achievement } \\
\text { Indicators Program (SAIP); Pan } \\
\text { Canadian Assessment Program } \\
\text { (PCAP); PISA scores; 1993-2012. } \\
\text { 3) Health and Well-Being data: } \\
\text { Canadian Community Health Survey } \\
\text { (CCHS) and Canadian Health } \\
\text { Measures Survey (CHMS); 2001- } \\
\text { 2013. } \\
\text { 4) Criminal Behavior: Stats Canada's } \\
\text { Uniform Crime Reporting Survey } \\
\text { (UCRS); years: 2006-2013. }\end{array}$ & $\begin{array}{l}\text { In 1997, Quebec introduced a very low cost } \\
\text { universal child care program for children } \\
\text { aged 0-4. This program increased maternal } \\
\text { labor supply and use of CC in Quebec (Baker, } \\
\text { Gruber, and Milligan, 2008). } \\
\text { DD: compare the pre and post program } \\
\text { outcomes of children/ teenagers in Quebec, } \\
\text { to the corresponding outcomes of } \\
\text { child/teenagers in the rest of Canada. } \\
\text { Models include province dummies, year } \\
\text { dummies, as well as individual controls. }\end{array}$ & $\begin{array}{l}\text { Children enrolled in child care at ages } 0-4 \text { in } \\
\text { Quebec: } \\
\text { Self-reported (worse) health: }+0.07 \text { SD }(+3.4 \%) \text { (a } \\
\text { positive effect means worse health). } \\
\text { Life satisfaction: }+0.30 \text { SD }(+14.0 \% \text { ) (a positive effect } \\
\text { means worse). } \\
\text { Quality of life: }+0.35 \text { SD }(+14.6 \% \text { ) (a positive effect } \\
\text { means worse). } \\
\text { Criminal behavior: } \\
\text { rates of accusations: }+3.7 \% \\
\text { rates of convictions: }+4.6 \% \\
\text { Test scores: no effects/opposing effects across } \\
\text { math/science } \\
\text { "There is no strong evidence that the Quebec } \\
\text { Family Plan had a lasting impact on children's } \\
\text { cognitive development". }\end{array}$ & $\begin{array}{l}\text { By gender: "effects on } \\
\text { criminal behavior, aggression, } \\
\text { and hyperactivity are } \\
\text { concentrated in boys, who } \\
\text { also see the largest } \\
\text { deterioration in non-cognitive } \\
\text { skills". }\end{array}$ \\
\hline
\end{tabular}




\begin{tabular}{|c|c|c|c|c|}
\hline Study & Micro - Data, N & Identification strategy and specification & Effects of the shock & $\begin{array}{c}\text { Heterogeneity in } \\
\text { mechanisms/effects }\end{array}$ \\
\hline \multicolumn{5}{|c|}{ Panel C: Child Care } \\
\hline $\begin{array}{l}\text { Campbell, Conti, } \\
\text { Heckman et al. } \\
\text { (2014). Effect of } \\
\text { Carolina } \\
\text { Abecedarian } \\
\text { Project on health } \\
\text { outcomes at age } \\
\text { 30. }\end{array}$ & $\begin{array}{l}\text { Surveys of children, parents, } \\
\text { teachers include data on cognition, } \\
\text { personality, health, achievement, } \& \\
\text { behavior; } \\
\text { participants followed at ages } 12,15 \text {, } \\
21,30 \text {, mid-30s. } \\
\text { Collected biomedical data (e.g., } \\
\text { blood samples). } \\
\mathrm{N}=111 \text { children ( } 57 \text { treat, } 54 \\
\text { control). }\end{array}$ & $\begin{array}{l}\text { Randomization of children into control \& } \\
\text { treatment groups. } \\
\text { Due to VERY small samples ( } \mathrm{N}=111 \text { ), authors } \\
\text { use estimation methods that involve exact } \\
\text { (small-sample) block permutation tests + } \\
\text { boostrapping of standard errors. }\end{array}$ & $\begin{array}{l}\text { Disadvantaged children randomly assigned to } \\
\text { treatment at 0-5 have: } \\
\text { 1) Fewer risk factors for cardiovascular \& metabolic } \\
\text { diseases in their mid-30s (stronger effects on } \\
\text { males): systolic blood press.: }-17 \mathrm{~mm} \mathrm{Hg} \text {; metabolic } \\
\text { syndrome (males): }-25 \% \text {; prehypertensive } \\
\text { (females): }-0.24 \text {; obesity \& hypertension: difference } \\
\text { of } 38.9 \% \text { btw treatments \& controls. } \\
\text { 2) More health care utilization at age } 30 \text { (males): } \\
+22.8 \% \text {. } \\
\text { 3) Lower risk of overweight in early-life (males): - } \\
40 \% \text {. Those who are obese at age } 30 \text { s were already } \\
\text { obese at ages } 0-5 \text {. }\end{array}$ & $\begin{array}{l}\text { Larger impacts on overweight, } \\
\text { obesity \& hypertension, } \\
\text { healthcare utilization for } \\
\text { males. }\end{array}$ \\
\hline $\begin{array}{l}\text { Carneiro and } \\
\text { Ginja (2014). } \\
\text { Effect of U.S. } \\
\text { Head Start } \\
\text { program on } \\
\text { outcomes } \\
\text { observed in } \\
\text { teens and young } \\
\text { adults. }\end{array}$ & $\begin{array}{l}\text { Children of the National } \\
\text { Longitudinal Survey of Youth } \\
\text { (CNLSY); annual survey from } 1979 \\
\text { until 1994 and biannual since then; } \\
\text { authors use until 2008. Nationally } \\
\text { representative. } \\
\mathrm{N}=5,433 \text { children 3-5. }\end{array}$ & $\begin{array}{l}\text { RD: exploit selection criteria on HH income } \\
\text { (\& on family size) } \\
\text { Main regressions include Head Start } \\
\text { participation, } \mathrm{HH} \text { income (measured at age } \\
\text { 4), \& a parametric but flexible function of } \mathrm{yr} \text {, } \\
\text { state, family size, family struct., HH income } \\
\text { (measured at age 4) } \\
\text { Discontinuity in the prob(take-up of HS) } \\
\text { around income eligibility threshold is not } \\
\text { sharp so authors instrument using } \\
\text { determinants of eligibility. } \\
\text { 1st stage only signif. for males (F-stat=17). }\end{array}$ & $\begin{array}{l}\text { Effects only estimated for boys (1st stage regression } \\
\text { only signif. for boys) } \\
\text { Participation in HS (IV results): } \\
\text { Overweight: - } 29 \% \text { ( } 0.74 \text { SD) } \\
\text { Needs special health equipment: - } 29 \% \text { ( } 1.29 \text { SD) } \\
\text { Behavioral problems: - } 0.6 \text { of a SD (not given as a \%) } \\
\text { Engagement in criminal act.: -22\% (young adults) } \\
\text { (0.56 SD) }\end{array}$ & No first stage for girls. \\
\hline
\end{tabular}




\begin{tabular}{|c|c|c|c|c|}
\hline Study & Micro - Data, N & Identification strategy and specification & Effects of the shock & $\begin{array}{c}\text { Heterogeneity in } \\
\text { mechanisms/effects }\end{array}$ \\
\hline \multicolumn{5}{|c|}{ Panel C: Child Care } \\
\hline $\begin{array}{l}\text { Conti, Heckman, } \\
\text { and Pinto (2015). } \\
\text { The impacts of } \\
\text { two early-life US } \\
\text { programs (Perry } \\
\text { Preschool } \\
\text { Project (PPP) \& } \\
\text { Carolina } \\
\text { Abecedarian } \\
\text { Project (ABC)) on } \\
\text { LT health and } \\
\text { health behaviors. }\end{array}$ & $\begin{array}{l}\text { 1) PPP longitudinal data: follow-ups } \\
\text { collected annually from age } 3 \text { until } \\
\text { 4th grade; includes measures of } \\
\text { intelligence, academic aptitude, } \\
\text { achievement tests, assessments of } \\
\text { socio-emotional development, } \\
\text { school records starting at } \\
\text { kindergarten through secondary } \\
\text { education. } \\
\text { 2) ABC longitudinal data: follow-ups } \\
\text { collected at ages } 12,15,21,30 \text {. } \\
N=7,400 \text {. }\end{array}$ & $\begin{array}{l}\text { Treatment randomization with long-term } \\
\text { follow-up: } \\
\text { The paper accounts for small sample sizes, } \\
\text { multiple hypothesis testing, and non-random } \\
\text { panel attrition. } \\
\text { Effects are estimated by gender due to both } \\
\text { biological and behavioral considerations. } \\
\end{array}$ & $\begin{array}{l}\text { Participating in an early-childhood program: } \\
\text { 1) PPP (outcome observed at ages } 27 \text { and } 40 \text { ): } \\
\text { Prob(having a healthy diet): +15pp (males) (no SD } \\
\text { available). } \\
\text { Prob(engaging in regular physical activity): +33pp } \\
\text { (females). } \\
\text { Prob(of being a daily smoker): -20pp (males) } \\
\text { Avg. N of cigarettes/day: falls from } 8.7 \text { @age } 27 \text { to } \\
6.5 \text { at @ } 40 \text { (males). } \\
\text { 2) ABC (outcome observed at age } 34 \text { ): } \\
\text { Obesity: no effects } \\
\text { Overweight: no effects } \\
\text { Prob(Diastolic blood pressure): - } 15 \% \text { (males) } \\
\text { Prob(Systolic blood pressure): -12\% (males) } \\
\text { Hypertension I: -76\% (males) } \\
\text { Hypertension II: -62\% (males) } \\
\text { Prob(ever been hospitalized): + } 35 \text { pp (males). }\end{array}$ & $\begin{array}{l}\text { Both programs improved the } \\
\text { health outcomes and healthy } \\
\text { behaviors of males only. } \\
\text { Externalizing behavior in early- } \\
\text { life is a key mediator of the } \\
\text { effect of PPP on smoking } \\
\text { among males, while } \\
\text { enhancements in cognitive } \\
\text { skills are a key mediator of } \\
\text { PPP on physical activity. } \\
\text { Task orientation and child's } \\
\text { BMI are important mediators } \\
\text { for high blood pressure and } \\
\text { hypertension in later-life } \\
\text { (males) in ABC. }\end{array}$ \\
\hline $\begin{array}{l}\text { Gelber and Isen } \\
\text { (2013). Effects } \\
\text { of Head Start on } \\
\text { parental } \\
\text { investments in } \\
\text { children. }\end{array}$ & $\begin{array}{l}\text { The Head Start Impact Study was an } \\
\text { experiment in which some children } \\
\text { were treated with Head Start while } \\
\text { the controls were not. Many } \\
\text { controls were in other preschools. } \\
\text { Outcomes were measured in the fall } \\
\text { of } 2002 \text { (after their enrollment in } \\
\text { HS) \& in the Spring of } 2003,2004 \text {, } \\
2005,2006 \text { ( } N=4,061 \text { children). }\end{array}$ & $\begin{array}{l}\text { Exploit the random selection of 1st-time } \\
\text { applicants (ages } 3 \& 4 \text { ) to HS for the fall of } \\
2002 \text {. } \\
\text { HS experiment: children on waiting lists for } \\
84 \text { nationally representative HS programs } \\
\text { ( } 353 \text { HS centers) were selected into: } \\
\text { Treatment: group enrolled in HS ( } N=2,479 \\
\text { children) } \\
\text { Control: group that was not granted access } \\
\text { to } \mathrm{HS} \text { ( } \mathrm{N}=1,582 \text { children). }\end{array}$ & $\begin{array}{l}\text { While enrolled in HS: Parental involvement w/child } \\
\text { (includes all activities): +0.15 SD. } \\
\text { Reading \& writing: }+0.19 \text { SD. Math: +0.19 SD. } \\
\text { Qualitative parenting: }+0.07 \text { SD. } \\
\text { Rules \& routines: } 0.12 \text { SD. Tracking child learning: } \\
0.23 \text { SD. } \\
\text { After child was enrolled in HS: Parental investment } \\
\text { in children: }+0.06 \text { SD. Reading \& writing: no effect. } \\
\text { Math: }+0.10 \text { SD. } \\
\text { Qualitative parenting: +0.07 SD. } \\
\text { Rules \& routines: }+0.09 \text { SD. } \\
\text { No effect on father involvement or parent-school } \\
\text { involvement in either condition. }\end{array}$ & $\begin{array}{l}\text { Across HS programs, } \\
\text { programs that raised } \\
\text { children's cognitive test } \\
\text { scores more also raised } \\
\text { parents' involvement } \\
\text { w/children. } \\
\text { No evidence of differential } \\
\text { impacts across: i) father } \\
\text { present; ii) gender; iii) Fall } \\
2002 \text { income of the parents; } \\
\text { iv) number of siblings; v) } \\
\text { whether child entered HS at } \\
\text { age } 3 \text { or } 4 .\end{array}$ \\
\hline
\end{tabular}




\begin{tabular}{|c|c|c|c|c|}
\hline Study & Micro - Data, N & Identification strategy and specification & Effects of the shock & $\begin{array}{c}\text { Heterogeneity in } \\
\text { mechanisms/effects }\end{array}$ \\
\hline \multicolumn{5}{|c|}{ Panel C: Child Care } \\
\hline $\begin{array}{l}\text { Gertler, } \\
\text { Heckman, Pinto, } \\
\text { et al. (2014). } \\
\text { Effect of } \\
\text { psychosocial } \\
\text { stimulation and } \\
\text { nutrition in } \\
\text { Jamaica on child } \\
\text { outcomes at age } \\
20-22 \text {. }\end{array}$ & $\begin{array}{l}\text { The Jaimaican Study: Longitudinal } \\
\text { data that follows ( } N=129 ; 64 \\
\text { treatment }+65 \text { control) poor \& } \\
\text { stunted children and a comparison } \\
\text { group ( } N=84 \text { ) of non-stunted. } \\
\text { Urban representative data were } \\
\text { used to compare samples: i) the } \\
1992 \text { Jamaican Survey of Living } \\
\text { Conditions; ii) the } 2008 \text { Jamaica } \\
\text { Labor Force. }\end{array}$ & $\begin{array}{l}\text { Randomized intervention: Treated/control } \\
\text { groups were all stunted, lived in same } \\
\text { neighborhoods, had same age/sex. The two } \\
\text { groups differ in terms of: mother's education } \\
\& \text { weight-for-height (treated group was more } \\
\text { disadvantaged) \& mother's employment } \\
\text { (treated group higher than control). The } \\
\text { comparison NON-stunted group is a more } \\
\text { advantaged group of children (although not } \\
\text { as advantaged as the average population in } \\
\text { urban Jamaica). }\end{array}$ & $\begin{array}{l}\text { Psychological stimulation treatment: } \\
\text { Earnings: }+42 \% \text { (effect sizes: na) } \\
\text { Employment or LFP: no effect. } \\
\text { Compared w/the NON-stunted group, treated } \\
\text { children catch-up in earnings, while the control } \\
\text { group (stunted children w/o intervention) lag } \\
\text { behind in earnings. } \\
\text { Nutrition supplementation treatment: } \\
\text { NO effects on ANY of the outcomes. }\end{array}$ & $\begin{array}{l}\text { Treated males are more likely } \\
\text { to be enrolled in school \& to } \\
\text { be enrolled full-time. Have a } \\
\text { higher cognitive factor \& are } \\
\text { more likely to be expelled } \\
\text { from school. } \\
\text { Females are more likely to } \\
\text { increase their years of } \\
\text { schooling, have any college } \\
\text { education, have higher exam } \\
\text { grades, \& better externalizing } \\
\& \text { internalizing behaviors. }\end{array}$ \\
\hline $\begin{array}{l}\text { Havnes and } \\
\text { Mogstad (2011). } \\
\text { Effect of being } \\
\text { born after a child } \\
\text { care reform in } \\
\text { Norway on } \\
\text { outcomes at age } \\
30 \text {. }\end{array}$ & $\begin{array}{l}\text { 1) Longitudinal database that covers } \\
\text { every resident from } 1967 \text { to } 2009 \text {, } \\
\text { includes rich data on all } \mathrm{HH} \\
\text { members; } N=341,170 \text { children. } \\
\text { 2) administrative register that } \\
\text { covers all child care institutions } \\
\text { eligible for public subsidies from } \\
\text { from } 1972 \text { to } 2009 \text {. } \\
\text { Datasets are merged using unique } \\
\text { identifiers for each individual. }\end{array}$ & $\begin{array}{l}\text { Exploit temporal \& spatial variation in child } \\
\text { care availability induced by the staged } \\
\text { expansion. } \\
\text { Compare adult outcomes for } 3 \text { to } 6 \text { year olds } \\
\text { before/after the reform, from municipalities } \\
\text { where CC expanded a lot \& municipalities } \\
\text { little increase. } \\
\text { Non-linear DD methods to estimate quantile } \\
\text { treatment effects \& local linear regression } \\
\text { estimates of the program effects by family } \\
\text { income. Order the municipalities by the pp } \\
\text { increase in CC coverage rates from } 1976 \text { to } \\
\text { 1997, divide sample at the median, the upper } \\
\text { half are treatment municipalities \& lower half } \\
\text { are the controls. }\end{array}$ & $\begin{array}{l}\text { The child care reform: } \\
\text { Earnings (age } 30):+9,000 \text { NOK peaks at the } 11 \text { th } \\
\text { percentile }(+2.5 \%=+0.06 \text { of a SD) } ;+5,000 \text { NOK bwt } \\
\text { the } 15 t-60 \text { th percentile }(+1.4 \%=0.03 \text { of a SD); \& } \\
\text { then fade out. } \\
\text { Gini coefficient: declined from } .306 \text { to } .296 \\
\text { "universal child care has a small but non-negligible } \\
\text { equalizing effect." } \\
\text { Intergenerational income elasticity: }-2.5 p p .\end{array}$ & $\begin{array}{l}\text { Results show substantial } \\
\text { heterogeneity in child care } \\
\text { effects by family income. } \\
\text { Children from high income } \\
\text { households suffer a mean loss } \\
\text { of } 8000 \text { NOK while children } \\
\text { from low income households } \\
\text { experience a gain of } 9000 \\
\text { NOK. No differences by } \\
\text { gender. }\end{array}$ \\
\hline
\end{tabular}




\begin{tabular}{|c|c|c|c|c|}
\hline Study & Micro - Data, N & Identification strategy and specification & Effects of the shock & $\begin{array}{c}\text { Heterogeneity in } \\
\text { mechanisms/effects }\end{array}$ \\
\hline \multicolumn{5}{|c|}{ Panel C: Child Care } \\
\hline $\begin{array}{l}\text { Heckman, Pinto, } \\
\text { and Savelyev } \\
\text { (2013). Effect of } \\
\text { Perry Preschool } \\
\text { on outcomes up } \\
\text { to age } 40 \text {. }\end{array}$ & $\begin{array}{l}\text { 1) Data on the Perry preeschool } \\
\text { randomized experiment: } N=123 \\
\text { children ( } 51 \text { females ( } 25 \text { treatment } \\
\& 26 \text { control) \& } 72 \text { males ( } 33 \\
\text { treatment \& } 39 \text { control)); follow- } \\
\text { ups: ages } 3-15,19,27 \text {, and } 40 \text {. }\end{array}$ & $\begin{array}{l}\text { 1) Exploit the randomized controlled trial } \\
\text { design of the program to identify the causal } \\
\text { effect of the treatment on measured skills } \\
\text { and on adult outcomes. } \\
\text { 2) Use an econometric model that estimates } \\
\text { the relationship btw outcomes \& } \\
\text { experimentally induced changes in measured } \\
\text { skills. } \\
\text { Three stage procedure: 1) estimate the } \\
\text { measurement system; 2) from the theoretical } \\
\text { equations in 1), estimate the skills for each } \\
\text { participant; 3) estimate the relationship btw } \\
\text { participant skills and lifetime outcomes. }\end{array}$ & $\begin{array}{l}\text { 1) Program effects on cognition and personality } \\
\text { skills (kernel density graphs): } \\
\text { Cognition (Stanford-Binet Intelligence Test): } \\
\text { increases only in the right tail of the distrib (and for } \\
\text { females). } \\
\text { Externalizing behavior: strong reductions for males } \\
\text { (at all levels of the distrib) and females (left tail). } \\
\text { Academic motivation: increases at all levels of the } \\
\text { distrib except at right tail (and for females only). } \\
\text { 2) Effect of cognition and personality skills on } \\
\text { outcomes: } \\
\text { Cognition: increases achievement tests and certain } \\
\text { labor market outcomes. } \\
\text { Externalizing behavior: affects crime, labor market, } \\
\text { and health behaviors. } \\
\text { Academic motivation: boosts education and } \\
\text { reduces LT unemployment. }\end{array}$ & $\begin{array}{l}\text { By gender: there are } \\
\text { significant differences. }\end{array}$ \\
\hline $\begin{array}{l}\text { Kline and } \\
\text { Walters (2016). } \\
\text { Re-examine the } \\
\text { Head Start } \\
\text { Impact Study. } \\
\text { Account for } \\
\text { participation of } \\
\text { controls in other } \\
\text { preschool } \\
\text { programs. }\end{array}$ & $\begin{array}{l}\text { The Head Start Impact Study was an } \\
\text { experiment in which some children } \\
\text { were treated with Head Start while } \\
\text { the controls were not. Many } \\
\text { controls were in other preschools. } \\
\text { Outcomes were measured in the fall } \\
\text { of } 2002 \text { (after their enrollment in } \\
\text { HS) and in the Spring of 2003, 2004, } \\
2005,2006 \text { ( } N=4,061 \text { children). }\end{array}$ & $\begin{array}{l}\text { Conduct a calibration exercise that accounts } \\
\text { for the fact that } 1 / 3 \text { of Head Start children } \\
\text { were drawn from another public preschool } \\
\text { setting. Thus, the cost of providing preschool } \\
\text { to these children is over-estimated if we } \\
\text { I ignore this. Also assumes that the short-run } \\
\text { impacts of Head Start on test scores are the } \\
\text { best predictors of future outcomes, in line } \\
\text { with previous studies which have shown } \\
\text { initial "fade out" followed by long-term } \\
\text { effects. }\end{array}$ & $\begin{array}{l}\text { Head Start is about as cost effective as other } \\
\text { publicly funded preschools, and under reasonable } \\
\text { assumptions, has positive rates of return. Ignoring } \\
\text { the fact that Head Start draws from other } \\
\text { preschools substantially overstates its cost. }\end{array}$ & $\begin{array}{l}\text { The children who are most } \\
\text { likely to benefit from Head } \\
\text { Start are least likely to } \\
\text { participate. Hence, an } \\
\text { expansion that brought these } \\
\text { chidlren into the program } \\
\text { would have even higher } \\
\text { payoffs. }\end{array}$ \\
\hline
\end{tabular}




\begin{tabular}{|c|c|c|c|c|}
\hline Study & Micro - Data, N & $\begin{array}{c}\text { Identification strategy and } \\
\text { specification }\end{array}$ & Effects of the shock & $\begin{array}{c}\text { Heterogeneity in } \\
\text { mechanisms/effects }\end{array}$ \\
\hline \multicolumn{5}{|c|}{ Panel D: Medical Care and Insurance } \\
\hline $\begin{array}{l}\text { Bharadwaj, } \\
\text { Loken, and } \\
\text { Nielson (2013). } \\
\text { Examine the } \\
\text { effect of } \\
\text { additional } \\
\text { medical care for } \\
\text { infants over } \\
1500 \text { g on infant } \\
\text { mortality and } \\
\text { test scores in } \\
\text { Norway and } \\
\text { Chile. }\end{array}$ & $\begin{array}{l}\text { Chile: } \\
\text { 1) Health: Vital statistics and death } \\
\text { records 1992-2007. N=6,109 births in the } \\
\text { bandwith of VLBW. } \\
\text { 2) Education records: 2002-2010 Universe } \\
\text { of students 1st-8th grades. } \\
95 \% \text { cases matched. } \\
\text { Norway: } \\
\text { 3) Health: Medical Birth Registry, } \\
\text { 1967-1993; universe, twins. } \\
\text { 4) Education: Norwegian Registry Data, } \\
\text { covers population, ages } 16-74 \text { in } \\
\text { 1986-2008. Includes basic SES data (educ, } \\
\text { age, labor mkt, family info, etc.). } \\
\mathrm{N}=2,477 \text { births in window. Test scores } \\
\text { measures at age 6-8. } \\
72 \% \text { cases are matched. }\end{array}$ & $\begin{array}{l}\text { RD: } \\
\text { Exploit variation in birth weight around the } \\
\text { cutoff of VLBW (1500gr) or less than } 32 \\
\text { weeks gestation to identify effect of } \\
\text { neonatal health care on } \\
\text { mortality/education. } \\
\text { Compare children just under and over } 1,500 \\
\text { grams to examine difference in outcomes as } \\
\text { a result of extra medical treatments. }\end{array}$ & $\begin{array}{l}\text { Being VLBW compared to children just above } \\
\text { 1,500gr: } \\
\text { Infant mortality: }-4.4 \mathrm{pp} \text { (Chile; avg infant } \\
\text { mortality =10.9\%), } \\
-3.1 \mathrm{pp} \text { (Norway; avg infant mortality }=4 \% \text { ). } \\
\text { Test scores: }+0.15 \text { of a SD (Chile; math score); } \\
0.22 \text { of a SD (Norway; national exam) . } \\
\text { Introduction of surfactant therapy helped } \\
\text { improve educational outcomes for VLBW. } \\
\text { Predicted effects on wages: }+2.7 \% \text { ( } 0.15 \mathrm{SD} \text { ) } \\
\text { (Chile); } 1.8 \% \text { (Norway). }\end{array}$ & NA \\
\hline $\begin{array}{l}\text { Daysal, Meltem, } \\
\text { Trandafir, and } \\
\text { Van Ewijk } \\
\text { (2015). Effects } \\
\text { of home delivery } \\
\text { on newborn } \\
\text { deaths in the } \\
\text { Netherlands. }\end{array}$ & $\begin{array}{l}\text { 1) Perinatal Registry of the Netherlands, } \\
2000-2008 \text {, annual dataset that links } 3 \\
\text { datasets of individual birth records } \\
\text { collected by midwifes (LVR-1), } \\
\text { obstetricians (LVR-2), \& pediatricians } \\
\text { (LNR), covers } 99 \% \text { of the primary care \& } \\
100 \% \text { of the secondary care provided } \\
\text { during pregnancy \& delivery in the } \\
\text { Netherlands, } N=356,412 \text { births. }\end{array}$ & $\begin{array}{l}\text { Use the variation in distance from a } \\
\text { mother's residence to the closest hospital } \\
\text { with an obstetric ward (exogeneity?) as an IV } \\
\text { for a hospital delivery. } \\
\text { Models include year, month, \& day of the } \\
\text { week of the birth FE, rich maternal controls, } \\
\text { and avg HH income in the postal code of } \\
\text { residence of the mother. }\end{array}$ & $\begin{array}{l}\text { Giving birth in a hospital vs. at home (IV } \\
\text { results): } \\
\text { A } 10.81 \text { pp increase in the share of hospital } \\
\text { births reduced 7-day ( } 28 \text {-day) mortality by } \\
49 \% \text { (46\%) btw } 1980-2009 \text { ). } \\
\text { 5-minute Apgar score: no effects } \\
\text { 1st stage: distance is a strong predictor of } \\
\text { whether she gives birth in a hospital or at } \\
\text { home (F-stat } ~ 28): 7.5 p p \text { (11\% at the mean). }\end{array}$ & $\begin{array}{l}\text { By income: baseline results are driven } \\
\text { entirely by births to mothers residing in } \\
\text { postal codes with less than the median of } \\
\text { the avgerage monthly HH income in the } \\
\text { postal code ( } 1,929 \text { euros). } 2 \text { SLS estimates } \\
\text { are similar when the sample is split by } \\
\text { maternal ethnicity, median age ( } 29 \\
\text { years), median gestational age ( } 280 \text { days) } \\
\text { or median birth weight ( } 3,410 \text { grams). }\end{array}$ \\
\hline
\end{tabular}

2) Statistics Netherlands data on income \&

educ. at the postal code level.

3) 2005 Dutch National Atlas of Public

Health for exact address and the

availability of obstetric wards for each

hospital. 


\section{Panel D: Medical Care and Insurance}

Sievertsen and 1) Danish National Birth Cohort (hospital Exploit county-by-county introduction of Same-day discharged newborns: Wust (2015). admissions), 1985-2006, $\mathrm{N}=714,562$ births. mandatory same-day discharge on the day

Effects of longer 2) Survey data: Danish National Birth of birth in a difference-in-differences

(+0.15 SD).

post partum Cohort, 1997-2003; pregnant women were framework.

hospitalizations invited to participate in 2 pre-birth \& up to

on mother and 4 post-birth surveys (at $6 \& 18$ months, 7 Models include county and year FE, as well years \& $11 \mathrm{yrs}$ ); includes maternal health as county-specific quadratic trends in birth

readmission and behaviors, investments in children's health year.

children's \& development, \& mother-reported child

schooling health; $\mathrm{N}=100,000$ births.

achievement at 3) Data on the 9th-grade GPA are available

age 7 in for cohorts who completed 9th-grade in

Denmark. 2002-2012 (cohorts born 1987-1997).
Readmission after 1st month: no change

$\mathrm{N}$ of contacts mother $\&$ child with general

practitioner in 1st month of child: +0.48

$(+126 \%=0.54 \mathrm{SD})$.

$\mathrm{N}$ of contacts mother \& child with general

practitioner up to age 3: no effect.

Children's 9th grade GPA: $-0.1 \mathrm{SD}$.

Test score in Danish: -0.12 SD.
Long term effects are strongest for at-risk children: "Children of at-risk mothers (defined by their age, education, income) appear to drive the negative effect of same-day discharge on schooling outcomes at age 15."

GPA: declines by -0.19 SD in the at risk group.

\begin{tabular}{|c|c|}
\hline Meyer and & 1) Admin data: mortality records from the \\
\hline Wherry (2016) & National Vital Statistics System (NVSS) \\
\hline examine the & Multiple Cause of Death files for the years \\
\hline effect of the & 1979 to 2011 \\
\hline Medicaid & 2) March Supplements to the Current \\
\hline $\begin{array}{l}\text { expansions on } \\
\text { mortality in }\end{array}$ & $\begin{array}{l}\text { Population Survey (CPS): use a random } \\
\text { sample of } 500 \text { children of ages } 0-17 \text { from }\end{array}$ \\
\hline affected cohorts. & $\begin{array}{l}\text { each year of the } 1981-1988 \text { CPS and } \\
\text { estimate the childhood eligibility for this } \\
\text { pooled sample for each birth month } \\
\mathrm{N}=864 \text { children (ages } 4-23 \text { ) }\end{array}$ \\
\hline
\end{tabular}

RD: exploit the discontinuity induced by Medicaid expansions that extended

eligibility only to children born after Sept. 30, 1983.

Poor children gained 5 additional years of eligibility if they were born in October 1983 rather than just one month before.

Control group: cohorts of children born just before the birthdate cutoff.
Children born after September 30, 1983

Internal-cause mortality rate: Ages 4-7, 8-14,

19-23: no effect.

Outcome at ages 15-18: -19\% (blacks only)

External-cause mortality rate:

Outcome at ages 4-7: no effect.

Outcome at ages 8-14: -13\% (blacks only).

Outcome at ages 15-18: $+8 \%$ (whites only). Outcome at ages 19-23: -10\% (blacks only).
By race: Medicaid expansions had a

sizeable decrease in the internal

mortality rate of older black teens. 


\begin{tabular}{|c|c|c|c|c|}
\hline Study & Micro - Data, N & $\begin{array}{l}\text { Identification strategy and } \\
\text { specification }\end{array}$ & Effects of the shock & $\begin{array}{c}\text { Heterogeneity in } \\
\text { mechanisms/effects }\end{array}$ \\
\hline \multicolumn{5}{|c|}{ Panel D: Medical Care and Insurance } \\
\hline $\begin{array}{l}\text { Miller and } \\
\text { Wherry (2014). } \\
\text { Effects of } \\
\text { Medicaid } \\
\text { expansions to } \\
\text { older children on } \\
\text { health status in } \\
\text { young } \\
\text { adulthood. }\end{array}$ & $\begin{array}{l}\text { 1) National Health Interview Survey (NHIS), } \\
\text { years } 1998 \text { to } 2012 \\
\mathrm{~N}=95,855 \text { individuals . } \\
\text { 2) Administrative data on hospitalizations } \\
\text { from the Nationwide Inpatient Sample } \\
\text { (NIS) provided by the Healthcare Cost \& } \\
\text { Utilization Project, includes data on } 46 \\
\text { states, } N=3 \text { million hospital visits } \\
\text { (excluding pregnancy). }\end{array}$ & $\begin{array}{l}\text { Exploit variation in the timing \& generosity } \\
\text { of Medicaid and SCHIP eligibility for } \\
\text { pregnant women \& children across states. } \\
\text { Construct a simulated eligibility measure of } \\
\text { the generosity of state eligibility rules to } \\
\text { instrument for the fraction of individuals } \\
\text { eligible for Medicaid coverage. } \\
\text { Authors construct Medicaid coverage } \\
\text { measures by age groups: prenatal period, } \\
\text { ages 1-4, 5-9, 10-14, 15-18. } \\
\text { Model: outcome regressed on Medicaid } \\
\text { eligibility in prenatal period, ages 1-4, 5-9, 10- } \\
14,15-18, \& \text { on individual \& state-level } \\
\text { control variables, state of residence, year of } \\
\text { birth (age), \& survey year dummies. }\end{array}$ & $\begin{array}{l}\text { A ten percentage point increase in eligibility } \\
\text { during the prenatal period (or during } \\
\text { childhood): } \\
\text { Obesity: }-1.4 \mathrm{pp}(-7 \%) \text { (no SD) (in utero). } \\
\text { BMI: -1.5 kg/m2 (-7\% = -0.25 SD) (in utero). } \\
\text { Adult hospitalizations (excluding pregnancy): - } \\
2.7 \% \text { (no SD) (ages 1-4). } \\
\text { Preventable hospitalizations: - } 7 \% \text { (in utero). } \\
\text { Hospitalizations related to endocrine, } \\
\text { nutritional, metabolic \& immunity disorders: - } \\
8 \% \text { (in utero). } \\
\text { No effects on health status, on any health } \\
\text { limitation, or on psychological distress (Kessler } \\
\text { scale). }\end{array}$ & Larger effectsof coverage in utero. \\
\hline
\end{tabular}

\begin{tabular}{|c|c|c|c|}
\hline $\begin{array}{l}\text { Wherry, Miller, } \\
\text { Kaestner, Meyer } \\
\text { (2015). Effects } \\
\text { of Medicaid } \\
\text { expansions to } \\
\text { older children on } \\
\text { health status in } \\
\text { young } \\
\text { adulthood. }\end{array}$ & $\begin{array}{l}\text { Uses data from the Healthcare Cost and } \\
\text { Utlization Project (individual level hospital } \\
\text { discharge and Emergency Department } \\
\text { records from participating states) to } \\
\text { examine exposure to Medicaid expansions } \\
\text { given state and year of birth on number of } \\
\text { visits as adults. } N \sim 58,000 \text {. }\end{array}$ & $\begin{array}{l}\text { RD: exploit the discontinuity induced by } \\
\text { several early Medicaid expansions that } \\
\text { extended eligibility only to children born } \\
\text { after September } 30,1983 \text {. } \\
\text { Treatment group: children in families with } \\
\text { incomes at or just below the poverty line } \\
\text { gained } 5 \text { additional years of eligibility if they } \\
\text { were born in October } 1983 \text { rather than just } \\
\text { one month before. } \\
\text { Control group: cohorts of children born just } \\
\text { before the birthdate cutoff. }\end{array}$ & $\begin{array}{l}\text { Children born after September 30, 1983: } \\
\text { At age 15: } \\
\text { Hospital visits: no effect. } \\
\text { Emergency department visits: no effect. } \\
\text { At age 25: } \\
\text { Hospital visits: no effect (for non-blacks) } \\
\text { Emergency department visits: no effect (for } \\
\text { non-blacks) }\end{array}$ \\
\hline
\end{tabular}

Effects were concentrated among Blacks: Hospital visits: $-7 \%$ to $-15 \%$ (Blacks only). Emergency department visits: -2 to $-5 \%$ (Blacks only).

No effects were observed on non-Blacks. before the birthdate cutoff. 


\section{Study \\ Micro - Data, N}

\section{Panel D: Medical Care and Insurance}

\section{Brown, Kowalski, 1) IRS-Compliance Data}

and Lurie (2015). Warehouse (CDW), 1996 -2012; allows

Expansions of individuals + parents to be followed

Medicaid $\quad \mathrm{N}=4,911,040$ females and 5,129,194 males. 90's.

coverage to Authors link children to parents in 1997, \& Authors exploit variation in total years of

older children follow the parents in all other years.

and effects on 2) Medicaid Statistical

labor force Information System (MSIS).

participation and 3) Social Security Administration data on income at age 28- mortality

31.

individual/HH controls.

IV (instrument: simulated eligibility based on
Exploit the variation in public insurance

eligibility by cohort \& state due to the

or each additional year of simulated

Medicaid eligibility:

By gender: "Females earned more in

cumulative wages by age $28 . "$

d payroll tax payments

(@age 31): $+\$ 1,561$ (of a base of $\$ 35,268$ )

$(+4.4 \%)$ (no dstandard deviations provided).

eligibility during childhood. Variation is at Income: $+\$ 186$ (on a base year of 20,623)

the state, month, and age group level. $\quad(+0.9 \%)$.

Models include $\mathrm{FE}$ for each birth month Years of education: +0.9 years (no avg. years

cohort \& each state at age 15, plus of schooling provided).

the fraction of the sample eligible for

Medicaid at state $\&$ cohort year, at each age from ages 0 to 18 ).

\begin{tabular}{ll}
\hline Cahodes, & 1) American Community \\
Kleiner, & Survey (ACS) 2005-2012, provides \\
Lovenheim, and & educational variables; allows matching \\
Grossman & each repondent to the state of birth. \\
$\begin{array}{ll}\text { (2016). Effects of } & \text { 2) March Current Population Survey (CPS), } \\
\text { Medicaid } & \text { used to calculate Medicaid eligibility by } \\
\text { expansions to } & \text { age, } \\
\text { older children on } & \text { state, year, \& race. } \\
\text { high school and } & \text { 3) Youth Risk Behavior Surveillance System } \\
\text { college } & \text { (YRBSS) to explore mechanisms (i.e. teen } \\
\text { education of 22- } & \text { health behaviors). } \\
\text { 29 year olds. } & \mathrm{N}=5,494 \text { obs. }\end{array}$
\end{tabular}

\section{Exploit the state-level expansions of}

Medicaid and the State Children's Health

insurance Program that took place in the 1980s \& 1990s.

V (instrument for actual eligibility using

Medicaid eligibility of a fixed population in each age, state, year, \& race).

Identification assumption: Medicaid rules

not changing due to unobserved cross-

cohort trends that also affect educational

attainment.

Models include rich aggregate-level controls, state-of-birth FE \& calendar year FE.

\section{A 10pp increase in avg Medicaid eligibility}

between the ages of 0-17:

IV results

High school drop-out: -0.5pp (-5\%) (-0.10 of a $\mathrm{SD})$.

College attendance: +0.7 to $1.0 p p$ ( 1 to $1.5 \%$ )

(0.08 of a SD).

( 0.08 of a SD).

\section{By race:}

An interaction between Medicaid Xa d

nonwhite shows that: "Medicaid

expansions helped to reduce the racial gap in HS completion..."

By age:

Authors show results of health insurance larger effects on older children. 


\section{Study Micro - Data, N \\ Panel E: Policies to Increase Maternal Education}

Carneiro, Costas, National Longitudinal Survey of

and Parey Youth 1979 (NLSY79), women and

(2012). Effect of their children only; annual survey changes in maternal

education on from 1979 to 1994 and biannual since. Authors use data until 2008. $\mathrm{N}=7,555$ children from 3,191 health and test mothers.

scores at ages 7 -

8 and $12-14$ in

the U.S.
IV approach: instrument for materal education A year of mother education (IV estimates): The effect of maternal is variation in schooling costs during the mom's Whites: Cognition (PIAT): $+9.4 \%$ of 1 SD education persists into adolescence (IVs: local tuition fees, distance to (math), $+5.5 \%$ (reading) (ages $7-8$ ); $+6.0 \%$ of adolescence. college, local labor market variables). Since IVs may be weak, authors also use a limited information maximum likelihood. Models include county \& cohort FE, \& aggregate trends as well rich controls for mother's ability.
$1 \mathrm{SD}$ (math), $+5.2 \%$ (reading) (ages $12-14$ ). Heterogeneity across races. Behavioral problems index: $-6.6 \%$ (ages 7 -

8), $-7.7 \%$ (ages 12-14). Grade repetition: $1.5 \%$ (ages $7-8$ ), $-2.1 \%$ (ages 12-14). Health (overweight/obesity): no effect. Blacks: Cognition (PIAT): $+10.3 \%$ of 1 SD (math), $+7.3 \%$ (reading) (ages $7-8$ ); $+8.3 \%$ of $1 \mathrm{SD}$ (math), +7.2\% (reading) (ages 12-14) Behavioral problems index: $-6.8 \%$ (ages 7 8), $-4.9 \%$ (ages 12-14). Grade repetition: $1.7 \%$ (ages 12-14).

Health (overweight/obesity): weak effects.

\section{McCrary and}

Royer (2011)

Effect of

mother's high

school education

on fertility and

infant health in

California and

Texas.
1) Administrative (confidential)

dataset on all births in CA \& TX data on mother's date of birth,

education, infant health, pregnancy

births per year.

2) Public-use Natality Detail Files, 1969-1988, (only years for which daily birth counts by state are available).
Exploit age-at-school-entry policies to identify Mother was born after the school entry

infant health (i.e., exploit the fact that the year Education at motherhood: -0.14 years (-

in which a person starts school is a discontinuous function of exact date of birth and determines when they can legally drop out).

Compare women born just before $\&$ after the Risky maternal behaviors: school entry date. Authors claim that school entry policies do not Drinking: -20\% (no SD). affect fertility. date: $1.3 \%)$ in CA and -0.24 years $(-2.1 \%)$ in TX (no standard deviations provided). (LBW, gestation, opposite sign." infant mortality). Maternal smoking: $+13 \%$ (no SD)

By race/ethnicity:

"For black women, the effect on LBW is consistent with education improving well-being, while for white women is of the Mother has STDs: no effect. 


\begin{tabular}{|c|c|c|c|c|}
\hline Study & Micro - Data, N & $\begin{array}{l}\text { Identification strategy and } \\
\text { specification }\end{array}$ & Effects of the shock & $\begin{array}{c}\text { Heterogeneity in } \\
\text { mechanisms/effects }\end{array}$ \\
\hline $\begin{array}{l}\text { Bharadwaj, } \\
\text { Eberhard, and } \\
\text { Neilson (2013). } \\
\text { Examines effects } \\
\text { of BW on test } \\
\text { scores from 1st } \\
\text { to } 12 \text { th grade in } \\
\text { Chile. }\end{array}$ & $\begin{array}{l}\text { 1) Chile's birth records, } 1992-2002 . \\
\text { Twins/siblings are identified by using a } \\
\text { mother ID; N=15,740 twin pairs. } \\
\text { 2) Education data comes from the RECH } \\
\text { (National student registry) database, the } \\
\text { SIMCE (Math, Science, \& Language Arts), } \\
\text { and the PSU dataset (college entrance } \\
\text { exam on math \& language), that consists } \\
\text { of administrative data on the grades/test } \\
\text { scores of every student in the country, } \\
2002-2008 ; \text { database provided by the } \\
\text { Ministry of Educ. of Chile. Approximately } \\
4 \text { million students observed } \sim 4 \text { times. }\end{array}$ & $\begin{array}{l}\text { Over time, depending on parental } \\
\text { preferences (compensatory or } \\
\text { reinforcing), test score diff's within sibling } \\
\text { or twin pairs will converge or diverge. } \\
\text { Parents may find it harder to invest } \\
\text { differentially in twins. Compare OLS, } \\
\text { sibling, and twin FE estimates. }\end{array}$ & $\begin{array}{l}\text { A } 10 \% \text { increase in BW: } \\
\text { Math \& language scores: }+0.04 \text { to } 0.06 \\
\text { of a SD. Relationship is stable from 1st } \\
\text { grade through HS. } \\
\text { Being VLBW: } \\
\text { Math \& language scores: }-0.1 \text { to }-0.2 \text { of } \\
\text { a SD. } \\
\text { OLS \& twins estimators are similar in } \\
1 \text { st grade( } 0.04 \text { of a SD) but OLS } \\
\text { estimates decline over time (e.g., in } 8 \text { th } \\
\text { grade the OLS estimate is } 0.2 \text { of a SD \& } \\
\text { the twins estimate is } 0.5 \text { of a SD). } \\
\text { Authors claim this is explained by } \\
\text { parental investment. }\end{array}$ & $\begin{array}{l}\text { By mother's educ: The relationship } \\
\text { btw BW \& test scores for children } \\
\text { (twins) of mothers with \& w/o a HS } \\
\text { degree is statistically identical ( } 0.04 \\
\text { of a SD due to a } 10 \% \text { increase in } \\
\text { BW) - a possible explanation for this } \\
\text { result is that inequality aversion } \\
\text { does not vary by mom's education. } \\
\text { By SES: similar relationships in low } \\
\text { and high SES schools/families. } \\
\text { Results show a non-linear } \\
\text { relationship btw BW \& academic } \\
\text { outcomes. }\end{array}$ \\
\hline
\end{tabular}

\begin{tabular}{|c|c|c|c|c|}
\hline $\begin{array}{l}\text { Figlio, Guryan, } \\
\text { Karbownik, and } \\
\text { Roth (2013). } \\
\text { Examines effects } \\
\text { of LBW on test } \\
\text { scores in 3-8th } \\
\text { grade in Florida. }\end{array}$ & $\begin{array}{l}\text { Universe of births in Florida from } 1992- \\
2002 \text { matched to subsequent universe of } \\
\text { Public school system records (includes } \\
\text { children in 3rd to } 8 \text { th grade) based on } \\
\text { first \& last name, DOB, SS\#. } \\
\text { Nearly all potentially matchable children } \\
\text { are matched. } \\
\text { Sample is conditioned on: those } \\
\text { remaining in the state of FL \& attending } \\
\text { public school. } \\
\text { Authors select twins (sample of twins is } \\
\text { followed from birth through middle } \\
\text { school). } \\
\mathrm{N}=14,000 \text { pairs of twins. }\end{array}$ & $\begin{array}{l}\text { Authors estimate Twin FE models (to } \\
\text { account for potential unobservable } \\
\text { determinants of cognitive ability that } \\
\text { could be correlated w/BW); neonatal } \\
\text { health is measured using In(BW); controld } \\
\text { for a gender dummy, and a dummy for } \\
\text { within-twin-pair birth order. } \\
\text { Authors hold gestation length constant. } \\
\text { Estimates are identified by variation in } \\
\text { fetal growth rates. }\end{array}$ & $\begin{array}{l}\text { A } 10 \% \text { increase in BW: } \\
\text { Cognitive test (Florida Comprehensive } \\
\text { Assessment Test, FCAT): }+0.045 \text { SD } \\
\text { (OLS: }+0.031 \text { of a SD). } \\
\text { Math test: }+0.050 \text { of a SD. } \\
\text { Reading: }+0.039 \text { of a SD. } \\
\text { Predicted effects on wages are: } 3 / 4 \text { of } \\
\text { those in Black, Devereux, and Salvanes } \\
\text { (2007). } \\
\text { Effects on cognition are } 60 \%-88 \% \text { of } \\
\text { those found in Black, Devereux, and } \\
\text { Salvanes (2007). } \\
\text { These effects do not change between } \\
\text { ages 9-14. }\end{array}$ & $\begin{array}{l}\text { Authors estimate models by: same } \\
\text { sex twins (vs opposite sex), gender, } \\
\text { same sex composition (GG vs BB), } \\
\text { mother's race, ethnicity, } \\
\text { immigration status, education ( }<12 \text {, } \\
12-15,>15) \text {, zip code median } \\
\text { income (bottom, middle, top), } \\
\text { marital status, age at birth ( }<=21,22 \text {. } \\
29,30-35,>=36 \text { ) and find: that a } \\
10 \% \text { increase in BW is associated } \\
\text { with a } 0.04 \text { SD increase in cognitive } \\
\text { tests for all. } \\
\text { Slightly larger effect for more } \\
\text { advantaged children. }\end{array}$ \\
\hline
\end{tabular}


Table 5: The "Missing Middle" and Latent Effects

\begin{tabular}{|c|c|c|}
\hline Micro - Data, N & $\begin{array}{l}\text { Identification strategy and } \\
\text { specification }\end{array}$ & Effects of the shock \\
\hline 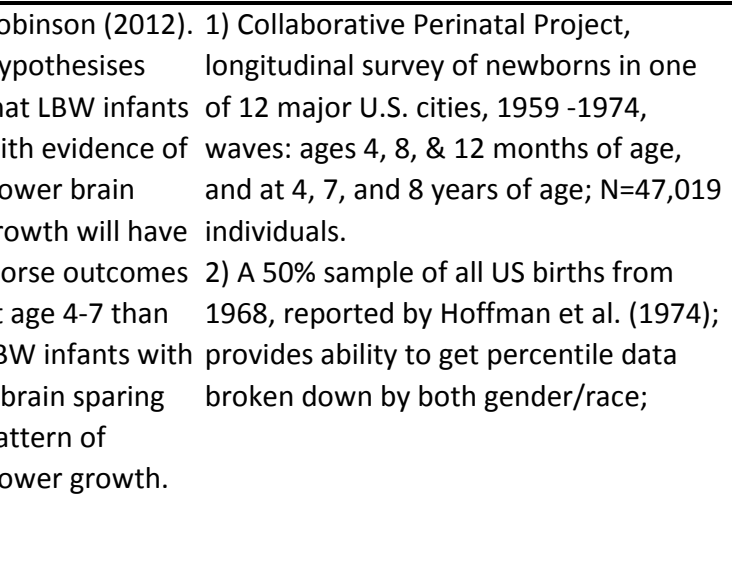 & $\begin{array}{l}\text { Decompose LBW infants into: i) those } \\
\text { whose head circumfrance is proportionate } \\
\text { to their weight; ii) those with evidence of } \\
\text { brain sparing. } \\
\text { Hypothesis: "Human capital should be } \\
\text { affected through decreased cognitive } \\
\text { function caused by brain growth } \\
\text { restriction in utero -- a potential } \\
\text { mechanism for the fetal origins } \\
\text { hypothesis." } \\
\text { Models regress child outcome on } \\
\text { indicators for whether a child was AGR \& } \\
\text { SGR, and on rich individual controls and } \\
\text { sibling FE. }\end{array}$ & $\begin{array}{l}\text { Find no cognitive effects of LBW in } \\
\text { group with brain sparing. In group with } \\
\text { effects on brain size: } \\
\text { Welsher IQ scores (ages } 4 \text { \& } 7):-3 \text { to - } \\
4 p p(-4.2 \%=0.27 \text { of a SD). } \\
\text { Congenital malformations: } 1.6 \text { times } \\
\text { higher. Prob(vision, hearing, \& speech } \\
\text { abnorm.): }+1.5 \text { to } 2.3 \text { times higher } \\
\text { Even with brain sparing: } \\
\text { Congenital malformations: } 1.3 \text { times } \\
\text { higher. Prob(vision, hearing, and } \\
\text { speech abnorm.): }+1.2 \text { to } 1.5 \text { times } \\
\text { higher. }\end{array}$ \\
\hline
\end{tabular}


Table 6: Summarizing the Effects of Shocks on Birth Weight, Test Scores, and Wages

\begin{tabular}{|c|c|c|}
\hline Shock & Study & Elasticity \\
\hline \multicolumn{3}{|c|}{ Panel A: Outcome= Birth Weight } \\
\hline Alcohol & Barreca and Page (2015) & $\begin{array}{l}\text { A 1-month increase in the minimun legal drinking age leads to a } 0.03 \% \text { decline } \\
\text { in LBW (or a statistically non-significant } 1.2 \% \text { decline on BW). }\end{array}$ \\
\hline Disease & Schwandt (2016) & $\begin{array}{l}\text { A } 10 \% \text { increase in maternal influenza hospitalizations in pregnancy leads to a } \\
0.2 \% \text { decline in BW (or a } 7.2 \% \text { increase in LBW). }\end{array}$ \\
\hline Income & $\begin{array}{l}\text { Almond, Hoynes, and } \\
\text { Schazenbach (2011) }\end{array}$ & $\begin{array}{l}\text { A } 10 \% \text { increase in annual income leads to a } 0.5 \% \text { increase in BW (or a } 6.0 \% \\
\text { decline in LBW). }\end{array}$ \\
\hline Income & $\begin{array}{l}\text { Hoynes, Miller, and Simon } \\
\text { (2015) }\end{array}$ & $\begin{array}{l}\text { A } 10 \% \text { increase in annual income leads to a } 1.0 \% \text { increase in BW (or a } 11.0 \% \\
\text { decline in LBW). }\end{array}$ \\
\hline Income & Rocha and Soares (2015) & $\begin{array}{l}\text { A } 10 \% \text { increase in rainfall shocks during pregnancy leads to a } 1.8 \% \text { decline in } \\
\text { BW (no LBW estimates are provided). }\end{array}$ \\
\hline Income \& Stress & Lindo (2011) & $\begin{array}{l}\text { Father's (own) unemployment leads to } 4.8 \% \text { decline in BW (or a statistically } \\
\text { non-significant } 2.5 \% \text { increase on LBW). }\end{array}$ \\
\hline Maternity leave & Rossin-Slater (2011) & $\begin{array}{l}\text { A 1-month increase in maternity leave during pregnancy leads to a } 0.16 \% \\
\text { increase in BW (or a }-0.16 \% \text { decline in LBW). }\end{array}$ \\
\hline Nutrition & $\begin{array}{l}\text { Almond and Mazumder } \\
\text { (2011) }\end{array}$ & $\begin{array}{l}\text { A 1-month increase in fetal nutritional disruption, leads to a } 0.6 \% \text { decline in BW } \\
\text { (no LBW estimates are provided). }\end{array}$ \\
\hline Nutrition & Rossin-Slater (2013) & $\begin{array}{l}\text { A } 10 \% \text { increase in the availability of WIC clinics leads to a } 0.4 \% \text { increase in BW } \\
\text { (or a } 1.7 \% \text { decline in LBW only for mothers with HS or less). }\end{array}$ \\
\hline
\end{tabular}

\begin{tabular}{|c|c|c|}
\hline Pollution & $\begin{array}{l}\text { Currie, Graff Zivin, } \\
\text { Meckel, Neidell, Schlenker } \\
\text { (2013) }\end{array}$ & $\begin{array}{l}\text { A } 10 \% \text { increase in pollution (the } \mathrm{N} \text { of districts with water contamination) leads } \\
\text { to a } 7.5 \% \text { increase in LBW (no BW estimates are provided). }\end{array}$ \\
\hline Pollution & Currie and Walker (2011) & $\begin{array}{l}\text { A } 10 \% \text { increase decline in NO2 from cars (along with associated decreases in } \\
\text { other pollutants leads to a } 10 \% \text { decline in LBW. }\end{array}$ \\
\hline Smoking & $\begin{array}{l}\text { Bharadwaj, } \\
\text { Johnsen, and Løken } \\
\text { (2014) }\end{array}$ & $\begin{array}{l}\text { A } 10 \% \text { decrease in smoking (the proportion of women smoking) during } \\
\text { pregnancy leads to a } 1.3 \% \text { decline in BW. }\end{array}$ \\
\hline Stress & Carlson (2015) & $\begin{array}{l}\text { A } 10 \% \text { increase in anticipated job losses in pregnancy leads to a } 0.2 \% \text { decline in } \\
\text { BW (or a } 16.0 \% \text { increase in LBW). }\end{array}$ \\
\hline Stress & $\begin{array}{l}\text { Persson and Rossin-Slater } \\
(2016)\end{array}$ & $\begin{array}{l}\text { Exposure to the death of a close relative during pregnancy reduces BW by } 0.5 \% \\
\text { (or a } 20 \% \text { increase in LBW). }\end{array}$ \\
\hline Stress & $\begin{array}{l}\text { Quintana-Domeque and } \\
\text { Rodenas-Serrano (2016) }\end{array}$ & $\begin{array}{l}\text { A } 10 \% \text { increase in violence (terrorist attacks) during pregnancy leads to a } 0.2 \% \\
\text { decline in BW (no LBW estimates are provided). }\end{array}$ \\
\hline Violence & Aizer (2011) & $\begin{array}{l}\text { A } 10 \% \text { increase in violence (the probability of personal assault) during } \\
\text { pregnancy leads to a } 10.0 \% \text { decline in BW (no LBW estimates are provided). }\end{array}$ \\
\hline \multicolumn{3}{|c|}{ Panel B: Outcome=Test Scores } \\
\hline Alcohol & $\begin{array}{l}\text { von Hinke Kessler } \\
\text { Scholder, Wehby, Lewis, } \\
\text { and Zuccolo (2014) }\end{array}$ & $\begin{array}{l}\text { A } 10 \% \text { increase in the probability of consuming alcohol during pregnancy leads } \\
\text { to a } 0.05 \text { SD decline in test scores. }\end{array}$ \\
\hline Disease & $\begin{array}{l}\text { Bhalotra and } \\
\text { Venkataramani (2013) }\end{array}$ & $\begin{array}{l}\text { A } 10 \% \text { decrease in diarrhea mortality rates leads to a } 0.14 \text { SD increase in test } \\
\text { scores. }\end{array}$ \\
\hline Disease & Venkataramani (2012) & $\begin{array}{l}\text { A } 10 \% \text { decline in the cases of malaria at the year of birth leads to a } 0.2 \text { SD } \\
\text { increase in test scores. }\end{array}$ \\
\hline Disease & Ward and Phipps (2014) & A 10 unit increase in the Influenza rate leads to a 0.3 SD decrease in test scores. \\
\hline Education (mother) & $\begin{array}{l}\text { Carneiro, Meghir, and } \\
\text { Parey (2012) }\end{array}$ & 1-year increase in mother's education leads to a 0.1 SD increase in test scores. \\
\hline
\end{tabular}


Table 6: Summarizing the Effects of Shocks on Birth Weight, Test Scores, and Wages

\begin{tabular}{|c|c|c|}
\hline Shock & Study & Elasticity \\
\hline \multicolumn{3}{|c|}{ Panel A: Outcome= Birth Weight } \\
\hline Income & $\begin{array}{l}\text { Black, Devereux, Løken, } \\
\text { and Salvanes (2014) }\end{array}$ & $\begin{array}{l}\text { A } 10 \% \text { increase in annual income at age } 5 \text { leads to a } 0.4 \text { SD increase in test } \\
\text { scores. }\end{array}$ \\
\hline Income & Dahl and Lochner (2012) & $\begin{array}{l}\text { A } 10 \% \text { increase in annual income at ages } 5-11 \text { leads to a } 0.15 \text { SD increase in test } \\
\text { scores. }\end{array}$ \\
\hline Income & $\begin{array}{l}\text { Milligan and Stabile } \\
(2011)\end{array}$ & $\begin{array}{l}\text { A } 10 \% \text { increase in annual income at ages } 0-5 \text { leads to a } 0.14 \text { SD increase in test } \\
\text { scores. }\end{array}$ \\
\hline Maternity leave & Baker and Milligan (2016) & $\begin{array}{l}\text { A 1-month increase in paid maternity leave at ages 6-12 months leads to a - } \\
0.057 \% \text { SD decline in test scores. }\end{array}$ \\
\hline Nutrition & $\begin{array}{l}\text { Almond, Mazumder, and } \\
\text { Van Ewijk (2011) }\end{array}$ & $\begin{array}{l}\text { A 1-month increase in fetal nutritional disruption (Ramadan exposure), reduces } \\
\text { test scores by } 0.07 \mathrm{SD} \text {. }\end{array}$ \\
\hline Nutrition & $\begin{array}{l}\text { Fitzsimons and Vera- } \\
\text { Hernandez (2014) }\end{array}$ & A 1-month increase in breastfeeding leads to a 0.2 SD increase in test scores. \\
\hline Nutrition & $\begin{array}{l}\text { Greve, Schultz-Nielsen, } \\
\text { Tekin (2015) }\end{array}$ & $\begin{array}{l}\text { A 1-month increase in fetal nutritional disruption (Ramadan exposure), reduces } \\
\text { female (ONLY) test scores by } 0.26 \mathrm{SD} \text {. }\end{array}$ \\
\hline Pollution (radiation) & $\begin{array}{l}\text { Black, Bütikofer, } \\
\text { Devereux, and Salvanes } \\
(2014)\end{array}$ & $\begin{array}{l}\text { A } 10 \text { unit increase in pollution (air/ground radiation) in utero leads to a } 0.3 \text { SD } \\
\text { decline in test scores. }\end{array}$ \\
\hline Pollution & $\begin{array}{l}\text { Bharadwaj, Gibson, Graff- } \\
\text { Zivin, and Nielsen (2016) }\end{array}$ & $\begin{array}{l}\text { A } 10 \text { unit increase in pollution (CO) in utero leads to a } 0.4 \text { SD decrease in test } \\
\text { scores. }\end{array}$ \\
\hline
\end{tabular}

\begin{tabular}{|c|c|c|}
\hline Pollution & Sanders (2012) & $\begin{array}{l}\text { A } 10 \text { unit decline in pollution (TSP) at the year of birth leads to a } 0.1 \text { SD increase } \\
\text { in test scores. }\end{array}$ \\
\hline Stress & $\begin{array}{l}\text { Aizer, Stroud, and Buka } \\
(2016)\end{array}$ & $\begin{array}{l}\text { A } 10 \% \text { increase in cortisol during pregnancy leads to a } 0.12 \text { SD decrease in test } \\
\text { scores. }\end{array}$ \\
\hline Weather & $\begin{array}{l}\text { Shah and Millett Steinberg } \\
\text { (2016) }\end{array}$ & $\begin{array}{l}\text { A } 10 \% \text { increase in the proportion of districts/year that experience a rainfall } \\
\text { shock leads to a } 0.02 \text { SD decline in test scores. }\end{array}$ \\
\hline Weather & $\begin{array}{l}\text { Aguilar and Vicarelli } \\
(2015)\end{array}$ & A $10 \%$ increase in rainfall shocks leads to a 0.02 SD decline in test scores. \\
\hline \multicolumn{3}{|c|}{ Panel C: Outcome=Wages } \\
\hline Alcohol & Nilsson (2015) & $\begin{array}{l}\text { A 1-month increase in alcohol exposure during pregnancy leads to a } 3.4 \% \\
\text { decrease in wages. }\end{array}$ \\
\hline Child care & $\begin{array}{l}\text { Gertler, Heckman, et al } \\
\text { (2014) }\end{array}$ & $\begin{array}{l}\text { A 1-month increase in psychosocial stimulation in early-life leads to a } 1.75 \% \\
\text { increase in wages. }\end{array}$ \\
\hline Child care & $\begin{array}{l}\text { Havnes and Mogstad } \\
\text { (2011) }\end{array}$ & A $10 \%$ increase in child care subsidies leads to a $1.4 \%$ increase in wages. \\
\hline Disease (worms) & $\begin{array}{l}\text { Baird, Hicks, Kremer, and } \\
\text { Miguel (2016) }\end{array}$ & $\begin{array}{l}\text { A 1-month increase in deworming school-aged children (age } 12 \text { ) leads to a } \\
0.15 \% \text { decrease in wages. }\end{array}$ \\
\hline Disease & $\begin{array}{l}\text { Bhalotra and } \\
\text { Venkataramani (2015) }\end{array}$ & $\begin{array}{l}\text { A } 10 \% \text { decline in infant pneumonia death rates leads to a } 7.0 \% \text { increase in } \\
\text { wages. }\end{array}$ \\
\hline Disease & $\begin{array}{l}\text { Beach, Ferrie, Saavedra, } \\
\text { and Troesken (2016) }\end{array}$ & A $10 \%$ decrease in typhoid mortality rate leads to a $5.0 \%$ increase in wages. \\
\hline Disease & Schwandt (2016) & $\begin{array}{l}\text { A } 10 \% \text { increase in maternal influenza hospitalizations in pregnancy leads to a } \\
1.1 \% \text { decline in wages. }\end{array}$ \\
\hline Health care & $\begin{array}{l}\text { Brown, Kowalski, and } \\
\text { Lurie (2015) }\end{array}$ & $\begin{array}{l}\text { A } 1 \text { year increase in Medicaid coverage eligibility at ages } 0-18 \text { leads to a } 4.8 \% \\
\text { increase in wages. }\end{array}$ \\
\hline Maternity leave & $\begin{array}{l}\text { Carneiro, Løken, and } \\
\text { Salvanes (2015) }\end{array}$ & A 1-month increase in paid maternity leave leads to a $1.4 \%$ increase in wages. \\
\hline Nutrition & Adhvaryu et al., (2016) & $\begin{array}{l}\text { A } 10 \% \text { increase in (the availability of) iodized salt in utero leads to a } 0.4 \% \\
\text { increase in wages. }\end{array}$ \\
\hline
\end{tabular}


Table 6: Summarizing the Effects of Shocks on Birth Weight, Test Scores, and Wages

Shock Study Elasticity

Panel A: Outcome= Birth Weight

Pollution Isen, Rossin-Slater, and

A 10-unit decrease in pollution (TSP) in-utero leads to a 1.0\% increase in wages. Walker (2015) 